\title{
Host specificity of co-infecting Botryosphaeriaceae on ornamental and forest trees in the Western Balkans
}

\author{
Milica Zlatković ${ }^{1,2}$, Michael J. Wingfield ${ }^{3}$, Fahimeh Jami ${ }^{3}$ and Bernard Slippers ${ }^{4}$ \\ ${ }^{1}$ Institute of Lowland Forestry and Environment (ILFE), University of Novi Sad, Novi Sad, Serbia \\ ${ }^{3}$ Department of Microbiology and Plant Pathology, Forestry and Agricultural Biotechnology Institute (FABI), University of \\ Pretoria, Pretoria, South Africa \\ ${ }^{4}$ Department of Genetics, FABI, University of Pretoria, Pretoria, South Africa \\ ${ }^{2}$ E-mail: milica.zlatkovic@uns.ac.rs (for correspondence)
}

\section{Summary}

The Botryosphaeriaceae is a diverse family of endophytes and fungal pathogens of mainly woody plants. We considered the host range and distribution of these fungi by sampling diseased ornamental and forest trees and shrubs in Serbia, Montenegro, Bosnia and Herzegovina, spanning a Mediterranean and a Continental climatic region. In total, ten Botryosphaeriaceae species were identified in the Western Balkans and with the exception of Sphaeropsis visci and Phaeobotryon cupressi, which occurred on one host, all the species had a broader host range. Phaeobotryon cupressi was found only in the Mediterranean region and S. visci, Dothiorella sp., Dothiorella sarmentorum and Diplodia seriata were present only in the Continental region. Pathogenicity tests were conducted on a variety of hosts from which the Botryosphaeriaceae species were isolated. These included leaves and/or stems of seedlings of 21 hosts, and cut leaves and/or branches of six hosts. Moreover stems of seedlings of Chamaecyparis lawsoniana, Cedrus deodara, Picea omorika, Pinus patula and Eucalyptus grandis were inoculated as hosts from which some or all of the Botryosphaeriaceae species used for inoculation were not isolated. Inoculations showed that the majority of these fungi could also co-infect hosts other than those from which they were isolated. The results suggest that most of the species have broad host ranges and can potentially cause disease on a broad range of tree species under certain conditions.

\section{Introduction}

Species of the Botryosphaeriaceae (Ascomycota: Botryosphaeriales) have a broad host range and occur in temperate, mediterranean and tropical climates worldwide (Phillips et al., 2013; Mehl et al., 2013). They can exist as endophytes in asymptomatic plant tissues, but some are also pathogens of agricultural and forestry crops. The shift from an endophytic to a pathogenic lifestyle often occurs after hosts have been subjected to stress caused by 
environmental factors such as drought, flooding or high temperatures (Slippers and Wingfield, 2007; Mehl et al., 2013). The recent increased pathogenic activity and geographic range expansion of the Botryosphaeriaceae in Europe has been linked to warmer climate and extreme weather (Fabre et al., 2011; Piškur et al., 2011; Adamson et al., 2015; Zlatković et al., 2016a).

A number of Botryosphaeriaceae infect multiple hosts, including some that are distantly related. Other Botryosphaeriaceae species appear to have a narrow host range. Examples include Botryosphaeria scharifii, Diplodia quercivora, Dothiorella brevicollis, Phaeobotryon mamane and Sphaeropsis visci, which have been found associated with Mangifera indica, Quercus canariensis, Acacia karroo, Sophora chrysophylla and Viscum album, respectively (Phillips et al., 2013; Jami et al., 2015). However, patterns of host preference in the Botryosphaeriaceae are considered questionable because sampling in most studies has focused on a particular tree species or geographical area (Jami et al., 2014). Moreover, multiple Botryosphaeriaceae often occur on the same host, and within individual host trees, tissues or sites (Slippers and Wingfield, 2007; Taylor et al., 2009; Sakalidis et al., 2013; Jami et al., 2014, 2015; Linaldeddu et al., 2014; Slippers et al., 2017).

Botryosphaeriaceae have mostly been reported from angiosperms, which appear to be the major group of plants on which these fungi have diversified (De Wet et al., 2008; Phillips et al., 2013; Slippers et al., 2013). However, some Botryosphaeriaceae predominantly infect conifers; i.e. Diplodia sapinea (syn. Diplodia pinea, Sphaeropsis sapinea), which shows a host preference mainly on Pinus, but is also found on Abies, Picea and Pseudotsuga (Pinales: Pinaceae); Diplodia scrobiculata associated with Pinus banksiana, P. resinosa, and P. greggii (Pinales: Pinaceae); Diplodia cupressi isolated from Cupressus and Juniperus spp. (Pinales: Cupressaceae); Diplodia tsugae isolated only from Tsuga heterophylla (Pinales: Pinaceae); and Phaeobotryon cupressi isolated from Cupressus sempervirens and Juniperus scopulorum (Pinales: Cupressaceae) (De Wet et al., 2008; Phillips et al., 2013; Slippers et al., 2013; Zlatković et al., 2017).

There are apparently few barriers to the Botryosphaeriaceae moving from native to non-native species and vice versa where hosts occur in the same geographic regions. For example, Diplodia seriata has been isolated from native Vitis vinifera and introduced Chamaecyparis lawsoniana and Thuja plicata in Portugal (Alves et al., 2013); D. sapinea has been found on various native Pinus spp. and introduced P. radiata in Italy (Luchi et al., 2014); Neofusicoccum mediterraneum has been found associated with native Sequoiadendron giganteum and introduced Pistacia vera in the USA (Inderbitzin et al., 2010); Neofusicoccum parvum has been found colonizing native 
Syzygium cordatum and introduced Eucalyptus grandis in South Africa (Pavlic et al., 2007; Pillay et al., 2013). Moreover, when they are isolated from native hosts of a region, Botryosphaeriaceae have also been able to infect and cause disease symptoms on introduced hosts existing in the same region in greenhouse trials (Pavlic et al., 2007).

Uncertainty regarding the taxonomy and overlapping morphological characters of the Botryosphaeriaceae have made these fungi difficult to identify (Phillips et al., 2013; Slippers et al., 2013). For this reason, the ecological role of Botryosphaeriaceae species has been poorly addressed in many ecosystems, including urban environments in which ecological interactions and evolution of species are still poorly understood (Shochat et al., 2006; Slippers and Wingfield, 2007; Begoude et al., 2010; Slippers et al., 2013; Zlatković et al., 2016a). In contrast to a large number of studies investigating the Botryosphaeriaceae diversity and impact in the Mediterranean region (MR) and in the tropics (e.g. Burgess et al., 2005; Rodas et al., 2009; Alves et al., 2014; Jami et al., 2014), less attention has been given to the Botryosphaeriaceae occuring in the Continental climate-type region (CR). Apart from some recent studies from the Balkans (e.g. Piškur et al., 2011; Zlatković et al., 2016a, b, 2017), most research on the Botryosphaeriaceae conducted in the CR has been focused on the pine pathogen, D. sapinea (e.g. Jankovský and Palovćiková, 2003; Karadžić and Milijašević, 2008; Fabre et al., 2011; Adamson et al., 2015).

In the Western Balkans, N. parvum, Botryosphaeria dothidea and D. seriata have been found to cause disease on V. vinifera, Malus domestica and Olea europaea (Latinović et al., 2013; Vasić et al., 2013; Kaliterna et al., 2012, 2013). Furthermore, a large number of Botryosphaeriaceae species has recently been found on various diseased trees in this region, including B. dothidea, N. parvum, D. sapinea, Diplodia mutila, D. seriata, Dothiorella sarmentorum, Dothiorella sp., Dothiorella omnivora, P. cupressi and S. visci (Zlatković et al., 2016a, b, 2017). These species have been found associated with both angiosperms and gymnosperms belonging to various families, i.e. Rosaceae, Fagaceae, Cupressaceae, Pinaceae, Oleaceae, Sapindaceae, Santalaceae, Pittosporaceae and Myrtaceae.

The aim of this study was to investigate the host range of the Botryosphaeriaceae in the Western Balkans. This was achieved by identifying species of the Botryosphaeriaceae from a broad collection of Botryosphaeriaceaelike isolates using the DNA sequence data for four gene regions. A selection of these isolates and isolates of the Botryosphaeriaceae identified in the previous study (Zlatković et al. 2016a) was then used to conduct reciprocal inoculations on the hosts from which the Botryosphaeriaceae had been isolated, as well as on C. lawsoniana, Cedrus deodara, Picea omorika, E. grandis and Pinus patula from which some or all of the Botryosphaeriaceae species 
were not isolated. The overlapping patterns of all Botryosphaeriaceae species identified in the Western Balkans (Zlatković et al. 2016a, b, 2017) was assessed at an individual plant, host species and geographic level.

\section{Materials and methods}

\subsection{Sample collection and Botryosphaeriaceae isolation}

Samples were collected from 84 trees (representing 28 species), ten shrubs (representing four species) and four seedlings (representing three species) between 2009 and 2014 in 12 cities, three villages, three forest stands and two ornamental nurseries in Serbia, Montenegro and Bosnia and Herzegovina (Tables S1, S2). Samples were collected from trees exhibiting various disease symptoms including cankers, die-back, and tissues displaying abundant resin flow (Table S3). The Botryosphaeriaceae were isolated from healthy and diseased tissues, as well as from fungal fruiting bodies on 2\% malt extract agar (MEA) plates acidified with lactic acid (AMEA) as described in Zlatković et al. (2016a). Fungal colonies were purified using hyphal tip transfers and Botryosphaeriaceae-like isolates (mycelium mostly fast-growing, white to greyish olive in color, often with a rosette appearance) were transferred to new Petri dishes. Representative isolates from each host have been maintained in the culture collection (CMW) of the Forestry and Agricultural Biotechnology Institute (FABI), University of Pretoria, South Africa.

Sampling was conducted in regions of Serbia, Montenegro and Bosnia and Herzegovina having both continental and mediterranean climates. According to the Köppen-Geiger system (Köppen 1936) continental climate with hot summers (Dwa) occurs in northern, eastern and central parts of Serbia and continental climate with dry summers (Dwb) occurs in western and southern parts of Serbia, Bosnia, Herzegovina and northern parts of Montenegro. Mediterranean climate (Csa) is found in the coastal area of Montenegro.

\subsection{DNA sequence analyses}

DNA was extracted from the mycelium of one-week-old cultures using PrepMan Ultra reagent (Applied Biosystems, Foster City, California) following the manufacturer's protocol. The ITS region of the rDNA operon was amplified using primer pairs ITS-1 and ITS-4 or ITS1F and ITS-4 (White et al., 1990; Gardes and Bruns, 1993); part of the TEF-1- $\alpha$ gene was amplified using primer pairs EF1-728F and EF1-986R (Carbone and Kohn, 1999) or EF1-F and EF2-R (Jacobs et al., 2004); the BT2 gene was amplified using primers Bt2a and Bt2b (Glass and Donaldson, 1995) and RPB2 gene was amplified using primers RPB2bot6F and RPB2bot7R (Sakalidis, 2004). The conditions and 
procedures for PCR amplification, PCR sequencing and sequence alignments were as those described in Zlatković et al. (2016a).

The phylogenetic analyses were performed using Maximum Parsimony (MP) and Maximum Likelihood (ML) analyses. The MP analyses were performed in PAUP version 4.0b10 (Swofford, 2003). The ML analyses were run using an online version of PhyML 3.0 (Guindon et al., 2010) and confidence levels were determined with 1,000 bootstrap replications (Felsenstein, 1985). For ML analyses the best nucleotide substitution model was found using jModelTest v.0.1 (Posada, 2008). Phylogenetic trees were created with MEGA v.6. The DNA sequences were deposited in GenBank (Table S2). A diagram that outlines materials and methods used in this study is presented in Figure S1.

\subsection{Botryosphaeriaceae species diversity}

Alpha diversity was estimated in terms of species richness S (number of species in the region/isolated from the host), the abundance (number of isolates) and evenness $\mathrm{J}$ (dominance of species in the region/isolated from the host). Shannon Wiener's index $(\mathrm{H})$ was calculated with $\mathrm{H}=\sum \mathrm{PilnPi}$ (Shannon and Weaver, 1949) and normalized to correct for differences in isolate numbers with $\mathrm{H}^{\prime}=\mathrm{H} / \mathrm{lnN}$, where $\mathrm{Pi}$ is the proportion of individuals in the $\mathrm{i}^{\text {th }}$ species and $\mathrm{N}$ is the number of isolates associated with each host. Values for $\mathrm{H}^{\prime}$ range from 0 (single species present) to 1 (each isolate associated with the particular host represent a different species).

Beta diversity was measured using the Jaccard's similarity index with $\mathrm{J}=\mathrm{a} /(\mathrm{a}+\mathrm{b}+\mathrm{c})$, where a represents the number of species occurring in both regions/gymnosperms-angiosperms, $b$ represents the number of species restricted to region 1/gymnosperms, and $\mathrm{c}$ represents the number of species restricted to region 2/angiosperms. The JI values range from 0 (no species shared) to 1 (all species shared) (Kumar and Hyde, 2004). Diversity indexes were calculated in R (R Core Team, 2015), using statistical package Vegan v. 2.2.1 (Oksanen et al., 2015). Botryosphaeriaceae species diversity in the Western Balkans was assesed using the whole collection of Botryosphaeriaceae isolates from the Western Balkans region, including isolates identified in this and in previous studies (Fig. S1; Zlatković et al. 2016a, b, 2017). 


\subsection{Inoculations of stems and leaves of seedlings in the field}

The inoculation tests were conducted during the 2014, 2015 and 2016 growing seasons, from April to October and from April to June, in an open-air nursery of the Faculty of Forestry in Belgrade, Serbia. Some of the seedlings (two or three-year-old potted plants) were obtained from the nursery of the Faculty of Forestry and others were purchased from a commercial ornamental nursery located in Novi Sad, Serbia. Seedlings were arranged in a completely randomized design and when rainfall was insufficient they were irrigated on a daily basis (Table S4).

Inoculations were done on stems of seedlings of 21 hosts from which Botryosphaeriaceae were isolated in this and in the previous study (Zlatković et al. 2016a; Tables S5,S6). When possible, inoculations were done using two isolates of both continental and Mediterranean origin of each species isolated from the given host (Tables S5, S7; Fig. S1). C. deodara and P. omorika were also inoculated with $N$. parvum isolate CMW 39327, which was not isolated from $C$. deodara and $P$. omorika neither in this nor in the previous study, but was shown to be very aggressive when inoculated on its natural hosts (Tables S5, S8; Fig. S5; Zlatković et al. 2016a). Because $C$. lawsoniana is one of the most frequently propagated ornamental tree in Serbian nurseries and a large number of seedlings of this host was available, to test for host specificity it was inoculated with nine Botryosphaeriaceae. Among them six Botryosphaeriaceae species were isolated from C. lawsoniana in this and in the previous study and three other Botryospaheriaceae used for inoculation were not isolated from C. lawsoniana (Table S5, Figs. S1, 5; Zlatković et al., 2016a). Inoculation experiments were repeated once.

Ten seedlings per species per isolate were inoculated $3-9 \mathrm{~cm}$ above the soil level of the stems by placing the mycelium in a wound made with a 3 or $6 \mathrm{~mm}$ diameter cork borer, as described in Zlatković et al. (2017). The same number of control seedlings of each species was inoculated with plugs of sterile water agar (WA). Seedlings were inspected for disease symptoms and mortality each week.

Leaves of $P$. laurocerasus seedlings were lightly wounded with a sterile needle and inoculated using isolates of $N$. parvum and D. mutila (Table S5) as described in Zlatković et al. (2016b). Ten leaves per $P$. laurocerasus seedling and ten seedlings per isolate were inoculated, giving a total of 40 seedlings and 400 leaves.

For seedlings of C. lawsoniana, Populus nigra var. italica, Prunus laurocerasus, P. abies, Q. robur, C. arizonica and Liriodendron tulipifera a score of 0-2, 1-3 or 1-2 was assigned to each Botryosphaeriaceae isolate used in the inoculation trial (Table1; Fig. S1).In the case of $Q$. robur and P. nigra var. italica the results were observed after six weeks when more then half of the plants inoculated with one isolate were girdled and dead. In the case of $P$. abies the results were observed after eight weeks when one of the isolates killed all the seedlings 
inoculated with that isolate. Since C. lawsoniana, C. arizonica and L. tulipifera did not experience mortality during inoculation trials the test lasted for the whole vegetation season (six months) for these tree species. Inoculation tests conducted on P. lauracerasus leaves lasted for three weeks and until all lesions formed by N. parvum isolate 39327 droped out of the leaves. Disease assessment for seedlings of S. giganteum, T. occidentalis, Abies concolor, C. sempervirens and $P$. omorika was based on the calculation of the Area Under Disease Progress Curve (AUDPC) and the test lasted until all of the inoculated plants were killed. The AUDPC was measured using the trapezoidal integration method (Madden et al., 2007):

$$
\operatorname{AUDPC}=\sum_{i=1}^{-1}\left[\left(\mathrm{y}_{\mathrm{i}}+\mathrm{y}_{\mathrm{i}+1}\right) / 2\right]^{*}\left(\mathrm{t}_{\mathrm{i}+1}-\mathrm{t}_{\mathrm{i}}\right)
$$

Where ' $n$ ' is the total number of observations, ' $y_{i}$ ' the severity of disease at the $i^{\text {th }}$ observation and ' $t_{i}$ ' time (week) at the $\mathrm{i}^{\text {th }}$ observation. Seedlings of Pittosporum tobira, C. deodara, C. atlantica, Ligustrum vulgare, Juniperus horizontalis, C. arizonica, P. laurocerasus, Magnolia grandifolia, Pseudotsuga menziesii, L. tulipifera, Taxus baccata, P. cerasus, Q. rubra, Platanus acerifolia and Forsythia europaea were sectioned longitudinally and the extent of resin accumulation/vascular discoloration was measured above and below the point of inoculation six weeks (for P. tobira, C. deodara, T. baccata, P. cerasus, Q. rubra, P. acerifolia and F. europaea) and six months (for all other species) after the beginning of the experiment. Botryosphaeriaceae were re-isolated from the margin between necrotic and apparently healthy tissue of inoculated plants. Fungal pycnidia were collected from the surface of the dead tissues and examined, as described in Zlatković et al. (2016b, 2017). Botryosphaeriaceae identity was verified based on the morphology of cultures and conidia in order to fulfil Koch's Postulates (Zlatković et al. 2016a). 
Table 1. Disease assessment for a variety of tree species inoculated with Botryosphaeriaceae isolates. Inoculations were conducted on leaves of Prunus laurocerasus seedlings in the field, on cut branches of Aesculus hippocastanum in laboratory conditions and on stems of seedlings of all other tree species in the filed.

Inoculated species

Disease assessment

Chamaecyparis lawsoniana

Populus nigra var. italica

\section{Prunus laurocerasus}

Picea abies

Quercus robur

Cupressus arizonica
O (not pathogenic) $=$ plants looking healthy, only resinous changes in the woody tissue were observed (B. dothidea CMW 39301, N. parvum, S. visci, Do. sarmentorum, D. mutila, D. seriata, Dothiorella sp.)

1 (moderately aggressive $)=>50 \%$ of plants with browning of the leaves from the inoculation point upwards and downwards, elliptical cankers (measuring $1.4-2.1 \mathrm{~cm}$ ) formed on the stems, pycnidia formed in the cankered tissue (B. dothidea CMW 39315) $2($ most aggressive $)=$ all plants with browning of the leaves, elongated, girdling, sunken cankers with vertical cracks within the canker and along the canker margins formed on the stems (measuring $>3 \mathrm{~cm}$ ), $P$. cupressi pycnidia formed in cankers ( $P$. cupressi)

0 $($ not pathogenic $)=$ plants looking healthy, no cankers were observed on the inoculated stems (B. dothidea)

$1($ less aggressive $)=<50 \%$ of plants girdled and dead, necrotic lesions (measuring $<3 \mathrm{~cm})$ formed on stems of all remaining plants (N. parvum CMW 39317)

2 (more aggressive $)=>50 \%$ of plants girdled and dead; sunken, girdling cankers with cracks within the canker (measuring $>3 \mathrm{~cm}$ ) and $N$. parvum pycnidia formed on stems of all remaining plants ( $N$. parvum CMW 39327)

0 (not pathogenic) $=$ lesions didn't appear on inoculated leaves (D. mutila CMW 39385) 1 (least aggressive $)=\operatorname{small}(3-5 \mathrm{~mm})$ lesions appeared around inoculation point but dropped out of the leaves (D. mutila CMW 39348)

$2($ moderately aggressive $)=$ reddish brown necrotic lesions $($ measuring $1-2.5 \mathrm{~cm})$ with concentric rings surrounded by reddish borer or light green halo appeared on leaves, $N$. parvum pycnidia formed in lesions, all lesions dropped out (N. parvum CMW 39327)

3 (most aggressive $)=$ reddish brown necrotic lesions (measuring $2.5-4 \mathrm{~cm}$ ) with concentric rings surrounded by reddish border or light green halo appeared on leaves, $<10 \%$ of lesions dropped out, $>50 \%$ of leaves were completely necrotic and detached and, $N$. parvum pycnidia formed in dead leaf tissue, $20 \%$ of plants experienced disease progress towards shoots which showed die-back and $N$. parvum pycnidia formed in dead shoot tissue (N. parvum CMW 39317)

1 (least aggressive $)=$ elongated, girdling, necrotic, resin-soaked lesions (measuring 2.5$6.5 \mathrm{~cm}$ ) formed on stems, some plants with shoot die-back (N. parvum CMW 39317)

2 (moderate aggressive $)=<50 \%$ of plants girdled and dead, remaining plants with elongated, resinous, girdling necrotic lesions (measuring $2.5-7.5 \mathrm{~cm}$ ), resin flow observed from the infected needles and stems (B. dothidea)

3 (most aggressive $)=$ all plants girdled and dead, resin flow observed from the infected needles and stems (D. sapinea ${ }^{1}$, N. parvum CMW 39327)

$1($ less aggressive $)=$ plants with elongated, girdling cankers (measuring 1.9-7.5 cm), pycnidia formed in cankered tissue (D. seriata CMW 39382)

$\mathbf{2}($ more aggressive $)=>50 \%$ plants girdled and dead, $D$. seriata pycnidia formed in dead plant parts, elongated, girdling cankers (measuring $>2 \mathrm{~cm}$ ) formed on all remaining plants, D. seriata pycnidia produced in the cankered tissue (D. seriata CMW 39376)

$1($ less aggressive $)=$ plants with elliptical necrotic lesions (measuring $<2 \mathrm{~cm})($ B. dothidea CMW 39301, D. mutila)

2 (more aggressive $)=$ plants with elongated, girdling, sunken cankers with vertical cracks within the canker and along the canker margins (measuring $>4 \mathrm{~cm}$ ), B. dothidea pycnidia formed in cankered tissue (B. dothidea CMW 39315) 
Table 1. Continued.

\begin{tabular}{|c|c|}
\hline Inoculated species & Disease assessment \\
\hline Liriodendron tulipifera & $\begin{array}{l}1 \text { (less aggressive })=\text { plants with lesions measuring } 5.4-8.3 \mathrm{~cm}(\text { B. dothidea } \mathrm{CMW} 39315) \\
2 \text { (more aggressive })=\text { plants with lesions measuring } 6-30 \mathrm{~cm},>50 \% \text { of plants with stem } \\
\text { die-back, B. dothidea pycnidia formed in dead stem tissue }(\text { B. dothidea } \text { CMW 39301) }\end{array}$ \\
\hline Aesculus hippocastanum & $\begin{array}{l}1 \text { (least aggressive) }=\text { branches with girdling lesions measuring } 1.5-4 \mathrm{~mm}, \text { Do. } \\
\text { sarmentorum pycnidia formed in lesions (Do. sarmentorum CMW 39365) } \\
2 \text { (moderately aggressive) }=>50 \% \text { of branches dried, girdled, with dark staining of the } \\
\text { vascular tissue, D. mutila pycnidia formed in the dead branch tissue }(D \text {. mutila CMW } \\
39385) \\
3 \text { (most aggressive) }=\text { all branches dried, girdled, with dark staining of the vascular tissue, } \\
\text { pycnidia formed in the dead branch tissue }(\text { B. dothidea, D. mutila CMW 39348, Do. } \\
\text { sarmentorum CMW } 39364, N \text {. parvum) }\end{array}$ \\
\hline
\end{tabular}

\subsection{Inoculations of cut branches and leaves of cut branches}

When seedlings were not available for the experimental trials, inoculations were done on cut branches. Cut branches, $30-40 \mathrm{~cm}$ in length and 1.3-1.5 cm thick, were collected from healthy mature Aesculus hippocastanum trees growing in the experimental forest of the Faculty of Forestry in Belgrade, Serbia in May 2015. Cut branches of the same length and width were also collected from healthy $P$. tremula, Fraxinus excelsior and $Q$. cerris trees growing in urban forests "Ada" and "Košutnjak", in Belgrade during May 2016. V. album shrubs showing no symptoms of disease were collected in October 2014 from Abies alba trees in “Košutnjak", Belgrade. Isolates used for inoculations of cut branches were selected according to the same principle as for inoculations of seedlings (Tables S5, S7; Fig. S1).

Ten branches per isolate were inoculated as described in Zlatković et al. (2017) and the same number of control branches was inoculated with sterile WA plugs. For branches of Aesculus hippocastanum a score of 1-3 was assigned to each of the Botryosphaeriaceae isolates used in the inoculation trial (Table1; Fig. S1). Ten V. album branches were wounded using a $3 \mathrm{~mm}$ cork borer and inoculated with a plug of 10-day-old S. visci mycelium, covered with moist cotton wool and wrapped with Parafilm (Pechiney, Chicago, USA). Ten leaves of ten V. album branches were lightly wounded with a sterile needle and inoculated as described previously. The same number of branches and leaves were inoculated with sterile WA plugs as controls.

After two weeks ( $V$. album) and three weeks (all other species), the extent of vascular discoloration on sectioned branches or lesions on leaves was measured and re-isolations were made as described in Zlatković et al. (2017). Experiments were repeated once. 


\subsection{Inoculations of stems of seedlings in the greenhouse}

To test for host specificity, inoculations were also conducted on twenty potted 5-year-old P. patula and 3-year-old E. grandis seedlings as hosts from which Botryosphaeriaceae strains from this study were not isolated. Seedlings were inoculated with the two most commonly found Botryosphaeriaceae species in this study, namely B. dothidea and N. parvum. Isolates used for inoculation were selected as described above (Tables S5-S7; Fig. S1). Seedlings were inoculated in the lower parts of the stems as described in Zlatković et al. (2017). Twenty control seedlings were inoculated with sterile WA plugs. Seedlings were watered daily, maintained at $25^{\circ} \mathrm{C}$ under natural day/night cycles and the lesion lengths were measured after six weeks. B. dothidea and N. parvum were re-isolated as described in Zlatković et al. (2017).

\subsection{Statistical analyses}

Statistical analyses were conducted using Statistica 8.0 (StatSoft Inc., Tulsa, OK, USA) and IBM SPSS Statistics 20.0 (New York, USA). The normality of the datasets was checked using Kolmogorov-Smirnov test and homogeneity of variances using Leven's test. The results of the two subsequent pathogenicity tests were analysed using Student's t-test at $\alpha=0.05$ (data not shown). Since no significant differences were found between the two repeats of the trials, a single dataset was used in further analyses. The $\log 10$ transformation was used to improve normality of the data set in order to analyse the effect of B. dothidea (CMW 39315) on vascular discoloration of $L$. tulipifera seedlings. The analyses were further assessed using either one way analyses of variance (ANOVA) followed by post-hock Fisher's Least Significant Difference (LSD) test, z-test (Pocock, 2006), Student's t-test or Kruskall-Wallis H test at $\alpha=0.05$.

\section{Results}

\subsection{Botryosphaeriaceae isolation}

A total of 188 Botryosphaeriaceae isolates were obtained in this study and 120 isolates obtained in the previous studies (Zlatković et al., 2016a, b, 2017) were included in the subsequent analyses. (Tables S1, S2; Fig. S1).

Among all samples collected in the Western Balkans, including those collected in this and in previous studies (Zlatković et al. 2016a, b, 2017), Botryosphaeriaceae were most frequently isolated from necrotic lesions and cankers ( $45.4 \%$ of the total samples), followed by resinous lesions and tissues $(22 \%)$. Botryosphaeriaceae were 
Table 2. Botryosphaeriaceae species isolated from different tree parts in this and in previous studies in the Western Balkans (Zlatković et al. 2016a, b, 2017). Values represent the number and percentage of samples from which Botryosphaeriaceae were isolated.

\begin{tabular}{|c|c|c|c|c|c|c|c|c|c|c|c|c|c|c|c|c|c|}
\hline \multirow[b]{2}{*}{$\begin{array}{c}\text { Botryosphaeriaceae } \\
\text { species }\end{array}$} & \multicolumn{6}{|c|}{ Resinous } & \multicolumn{4}{|c|}{ Necrotic/Cankered } & \multirow[b]{2}{*}{$\begin{array}{c}\text { Top } \\
\text { dieback }\end{array}$} & \multirow[b]{2}{*}{$\begin{array}{c}\text { Wood } \\
\text { discoloration }\end{array}$} & \multirow[b]{2}{*}{$\begin{array}{l}\text { Fruit } \\
\text { bodies }\end{array}$} & \multirow[b]{2}{*}{ Dead } & \multirow[b]{2}{*}{ Healthy } & \multirow[b]{2}{*}{ Total } & \multirow[b]{2}{*}{$\%$} \\
\hline & 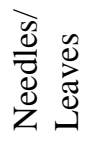 & $\begin{array}{l}\overrightarrow{8} \\
\stackrel{0}{n}\end{array}$ & 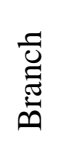 & $\frac{\Xi}{\mathscr{D}}$ & 㒸 & $\stackrel{\tilde{0}}{0}$ & 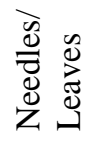 & $\begin{array}{r}\ddot{8} \\
\stackrel{0}{n}\end{array}$ & 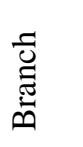 & $\underset{\tilde{D}}{\tilde{D}}$ & & & & & & & \\
\hline Diplodia sapinea & 3 & 1 & 13 & 17 & 0 & 5 & 0 & 4 & 6 & 12 & 4 & 1 & 13 & 6 & 2 & 87 & 28.2 \\
\hline D. mutila & 0 & 0 & 1 & 1 & 0 & 1 & 0 & 4 & 1 & 5 & 0 & 1 & 3 & 1 & 0 & 18 & 5.8 \\
\hline D. seriata & 0 & 1 & 2 & 0 & 0 & 0 & 3 & 1 & 4 & 4 & 0 & 2 & 4 & 3 & 0 & 24 & 7.8 \\
\hline Dothiorella sp. & 0 & 0 & 0 & 0 & 0 & 0 & 1 & 0 & 1 & 1 & 0 & 0 & 1 & 1 & 0 & 5 & 1.6 \\
\hline Do. omnivora & 0 & 0 & 0 & 0 & 0 & 0 & 2 & 0 & 2 & 1 & 0 & 1 & 1 & 0 & 0 & 6 & 1.9 \\
\hline Do. sarmentorum & 0 & 0 & 1 & 0 & 0 & 0 & 2 & 3 & 0 & 2 & 0 & 0 & 2 & 1 & 0 & 11 & 3.6 \\
\hline Botryosphaeria dothidea & 2 & 0 & 4 & 3 & 2 & 0 & 20 & 9 & 11 & 13 & 10 & 5 & 11 & 8 & 1 & 99 & 32.1 \\
\hline Neofusicoccum parvum & 0 & 1 & 6 & 2 & 0 & 0 & 11 & 8 & 2 & 11 & 2 & 6 & 2 & 4 & 1 & 56 & 18.2 \\
\hline Sphaeropsis visci & 0 & 0 & 0 & 0 & 0 & 0 & 0 & 0 & 0 & 0 & 0 & 0 & 1 & 0 & 0 & 1 & 0.3 \\
\hline Phaeobotryon cupressi & 0 & 0 & 1 & 0 & 0 & 0 & 0 & 0 & 0 & 0 & 0 & 0 & 0 & 0 & 0 & 1 & 0.3 \\
\hline Total & 5 & 3 & 29 & 23 & 2 & 6 & 38 & 28 & 26 & 48 & 16 & 15 & 38 & 26 & 4 & 308 & 100 \\
\hline$\%$ & 1.6 & 1 & 9.4 & 7.5 & 0.6 & 1.9 & 12.3 & 9.1 & 8.4 & 15.6 & 5.2 & 4.9 & 12.3 & 8.4 & 1.3 & 100 & \\
\hline
\end{tabular}


only occasionally isolated from healthy tissues $(1.3 \%)$, discolored wood (4.9\%) and margins between apparently healthy and dead stem wood of trees with top die-back (5.2\%) (Table2).

\subsection{DNA sequence analyses}

Preliminary identification of the isolates obtained in this study was made using MP analyses of the ITS sequences (tree not shown). Isolates of N. parvum were further subjected to analyses of the combined ITS, TEF-1- $\alpha$, BT2 and RPB2 gene regions (trees not shown). Based on these analyses, isolates considered in this study were identified as $D$. seriata, D. mutila, B. dothidea, Do. sarmentorum, Do. omnivora and $N$. parvum. Representative isolates from each host of each identified fungal species including four that were previously identified, namely Dothiorella sp., $S$. visci, $P$. cupressi and D. sapinea (Zlatković et al., 2016a, 2017) were further subjected to MP and ML analyses of the ITS sequence data (Figs. 1, S1).

The ITS data set contained 145 sequences and was rooted to Pseudofusicoccum stromaticum (CBS 117448, CBS 117449). The sequence data set contained 528 characters among which 150 were parsimony informative, 378 were parsimony uninformative, with $\mathrm{CI}=0.8, \mathrm{RI}=0.9$ and $\mathrm{TL}=247$. The model $\mathrm{GTR}+\mathrm{G}$ was chosen for the $\mathrm{ML}$ analyses $(\mathrm{G}=0.2050)$. The topologies of the trees emerging from MP and ML analyses were similar and therefore, only ML tree is presented (Fig. 1).

\subsection{Botryosphaeriaceae species diversity}

Among the whole collection of isolates of Botryosphaeriaceae species from the Western Balkans, including isolates from this study and from previous studies (Zlatković et al. 2016a, b, 2017) the most commonly isolated species was $B$. dothidea (32.1\%), followed by D. sapinea (28.2\%) and N. parvum (18.2\%). Do. omnivora (1.9\%), Dothiorella sp. (1.6\%), S. visci $(0.3 \%)$ and P. cupressi $(0.3 \%)$ were isolated only occasionally. The majority of the Botryosphaeriaceae were most commonly isolated from necrotic lesions and cankers. Exceptions were $D$. sapinea that was most frequently isolated from resinous lesions and tissues $(44.8 \%)$, . visci isolated from pycnidia and $P$. cupressi isolated only from resinous branch lesion (Table 2).

There were significant differences $(\mathrm{F}=7.85, \mathrm{df}=9, \mathrm{p}=0)$ in host association patterns among Botryosphaeriaceae species from the Western Balkans from this and from previous studies (Zlatković et al. 2016a, b, 2017). P. cupressi, S. visci and Dothiorella sp. showed the strongest host association patterns being isolated from a 

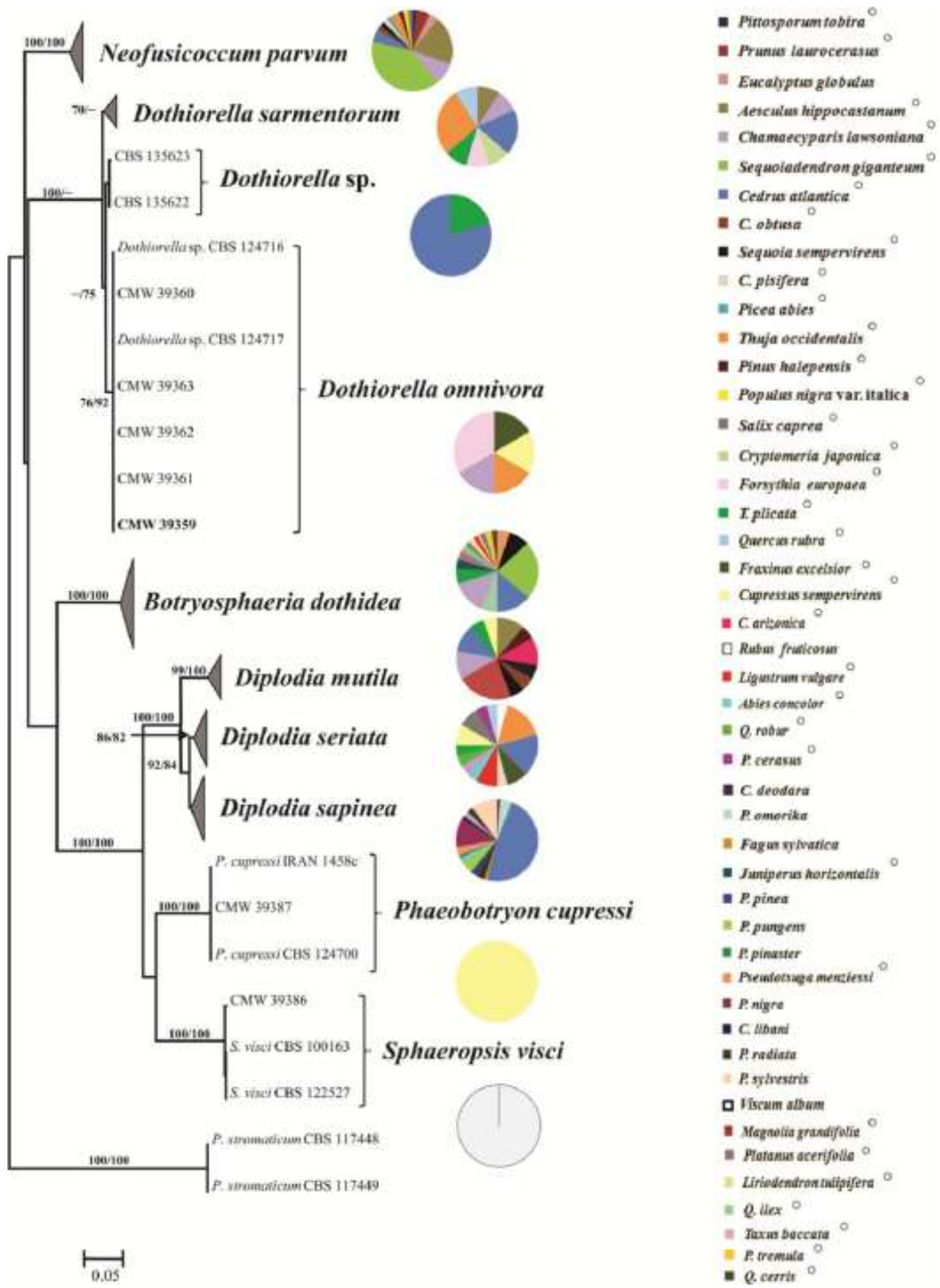

Figure 1. Maximum likelihood (ML) tree of the ITS sequence data. The bootstrap support values (MP/ML $\geq 70 \%)$ are indicated at the nodes and the scale bar represents the number of changes. The tree was rooted to P. stromaticum CBS 117448 and CBS 117449. Isolates sequenced in this study are presented in bold. Branches corresponding to Botryosphaeriaceae species that were isolated from more than five hosts are collapsed. Collapsed branches are displayed as gray triangles and the size of a triangle is proportional to the number of hosts. Pie charts indicate the hosts from which species were isolated. Hosts from this study are indicated with the circles. 
single host or two hosts, respectively. Each of the remaining seven Botryosphaeriaceae species showed unique host association patterns (Fig. 1When considering only isolates from this study, new host associations were found for Do. sarmentorum, , Do. omnivora, B. dothidea, D. mutila, D. seriata and N. parvum (Table S9). Shannon Weiner's diversity index $\left(\mathrm{H}^{\prime}\right)$ showed greatest Botryosphaeriaceae diversity associated with $T$. occidentalis $\left(\mathrm{H}^{\prime}=0.61\right)$, followed by $T$. plicata $\left(\mathrm{H}^{\prime}=0.53\right)$ and 27 hosts harbored a single species. High values of Evenness $(\mathrm{J}=0.58-0.91)$ indicated even communities of species for most hosts (Table3). There were significant differences $(\mathrm{F}=1.61, \mathrm{df}=46$, $\mathrm{p}=0.009$ ) in the composition and diversity of Botryosphaeriaceae among different hosts (Table3, Fig. S2).

There were no significant differences $(H=0.37, \mathrm{df}=1, \mathrm{p}=0.54)$ in the diversity of Botryosphaeriaceae species associated with angiosperms $\left(H^{\prime}=0.42\right)$ compared to gymnosperms $\left(H^{\prime}=0.29\right)$. High values of Evenness (0.76 and 0.8 ) showed that the communities are relatively similar. Jaccard's index showed relatively high overlap of species isolated from gymnosperms and angiosperms $\left(\mathrm{J}^{\prime}=0.7\right.$, Table S10). The species composition differed in such a way that $S$. visci was found only on angiosperms, Dothiorella sp. and P. cupressi were isolated only from gymnosperms, $B$. dothidea and $D$. seriata were isolated from gymnosperms and angiosperms with almost equal frequency and all the rest of the Botryosphaeriaceae species were most commonly isolated from gymnosperms (Table S10).

There were no significant differences $(\mathrm{H}=2.28, \mathrm{df}=1, \mathrm{p}=0.13)$ of Botryosphaeriaceae species diversity in the Continental region $(\mathrm{CR})\left(\mathrm{H}^{\prime}=0.30\right)$ compared to the Mediterranean region $(\mathrm{MR})\left(\mathrm{H}^{\prime}=0.37\right)$. High values of Evenness indicated almost even distribution of species (0.77 and 0.8) and Jaccard's index showed moderate overlap of species $\left(\mathrm{J}^{\prime}=0.5\right)$. D. seriata, Do. sarmentorum, Dothiorella sp. and S. visci were found only in the CR; $P$. cupressi was found only in the MR and five species were found in both climatic regions (Table S11, Figure S3).

Individual trees, tree parts and lesions were often colonized by several Botryosphaeriaceae species. Up to five species were found co-habiting the same diseased host tree and up to three species were isolated from the same diseased tree parts (Table S12). B. dothidea and N. parvum were most commonly found co-habiting the same host trees $(16 \%)$; B. dothidea was found most frequently (30.6\%) in the same host tree and in same tree part (24.5\%) in combination with other species (Table S13) and multiple Botryosphaeriaceae species were most commonly isolated from C. atlantica $(22.2 \%$, Table S14). 
Table 3. Diversity and overlap of Botryosphaeriaceae species isolated from different hosts in this and in previous studies in the Western Balkans (Zlatković et al. 2016a, b, 2017)

\begin{tabular}{|c|c|c|c|c|c|}
\hline Host & $\begin{array}{c}\text { Species } \\
\text { richness (S) }\end{array}$ & Abundance & $\begin{array}{l}\text { Shannon } \\
\text { index (H') }\end{array}$ & $\begin{array}{c}\text { Evenness } \\
\text { (J) }\end{array}$ & LSD \\
\hline \multicolumn{6}{|c|}{ Gymnosperms } \\
\hline Chamaecyparis lawsoniana & 7 & 26 & 0.44 & 0.73 & $A$ \\
\hline Cedrus atlantica & 7 & 71 & 0.30 & 0.66 & $A$ \\
\hline Cupressus sempervirens & 5 & 6 & & & $\mathrm{~B}$ \\
\hline Thuja plicata & 5 & 10 & 0.53 & 0.76 & $\mathrm{~B}$ \\
\hline Thuja occidentalis & 5 & 11 & 0.61 & 0.91 & $\mathrm{~B}$ \\
\hline Abies concolor & 3 & 5 & & & $\mathrm{D}$ \\
\hline Sequoiadendron giganteum & 3 & 47 & 0.22 & 0.76 & $\mathrm{D}$ \\
\hline Pinus halepensis & 3 & 4 & & & $\mathrm{D}$ \\
\hline Sequoia sempervirens & 3 & 10 & 0.28 & 0.58 & $\mathrm{D}$ \\
\hline Chamaecyparis pisifera & 2 & 2 & & & $\mathrm{D}$ \\
\hline Chamaecyparis obtusa & 2 & 2 & & & $\mathrm{D}$ \\
\hline Cupressus arizonica & 2 & 4 & & & $\mathrm{D}$ \\
\hline Pseudotsuga menziesii & 2 & 8 & & & $\mathrm{D}$ \\
\hline Juniperus horizontalis & 2 & 5 & & & $\mathrm{D}$ \\
\hline Picea abies & 2 & 2 & & & $\mathrm{D}$ \\
\hline Pinus nigra & 1 & 10 & 0 & 0 & $\mathrm{E}$ \\
\hline Pinus sylvestris & 1 & 9 & & & $E$ \\
\hline Cedrus deodara & 1 & 1 & & & $\bar{E}$ \\
\hline Picea pungens & 1 & 4 & & & $E$ \\
\hline Picea omorika & 1 & 4 & & & $E$ \\
\hline Cedrus libani & 1 & 1 & & & $\mathrm{E}$ \\
\hline Pinus radiata & 1 & 2 & & & $E$ \\
\hline Pinus pinea & 1 & 1 & & & $\mathrm{E}$ \\
\hline Pinus pinaster & 1 & 1 & & & $E$ \\
\hline Cryptomeria japonica & 1 & 1 & & & $E$ \\
\hline Taxus baccata & 1 & 1 & & & $E$ \\
\hline \multicolumn{6}{|c|}{ Angiosperms } \\
\hline Aesculus hippocastanum & 4 & 16 & 0.34 & 0.69 & C \\
\hline Salix caprea & 2 & 4 & & & $\mathrm{D}$ \\
\hline Prunus laurocerasus & 2 & 7 & & & $\mathrm{D}$ \\
\hline Fraxinus excelsior & 2 & 3 & & & $\mathrm{D}$ \\
\hline Pittosporum tobira & 2 & 2 & & & $\mathrm{D}$ \\
\hline Quercus rubra & 3 & 3 & & & $\mathrm{D}$ \\
\hline Quercus ilex & 1 & 6 & & & $\mathrm{E}$ \\
\hline Ligustrum vulgare & 1 & 2 & & & $E$ \\
\hline Populus tremula & 1 & 2 & & & $\mathrm{E}$ \\
\hline Eucalyptus globulus & 1 & 2 & & & $\mathrm{E}$ \\
\hline Platanus acerifolia & 1 & 2 & & & $E$ \\
\hline Viscum album & 1 & 1 & & & $\mathrm{E}$ \\
\hline Forsythia europaea & 1 & 1 & & & $E$ \\
\hline Magnolia grandiflora & 1 & 1 & & & $\bar{E}$ \\
\hline Liriodendron tulipifera & 1 & 1 & & & $\mathrm{E}$ \\
\hline Fagus sylvatica & 1 & 1 & & & $E$ \\
\hline Quercus robur & 1 & 1 & & & $\mathrm{E}$ \\
\hline Rubus fruticosus & 1 & 1 & & & $E$ \\
\hline Populus nigra var. italica & 2 & 2 & & & $E$ \\
\hline Prunus cerasus & 1 & 1 & & & $\mathrm{E}$ \\
\hline Quercus cerris & 1 & 2 & & & $\mathrm{E}$ \\
\hline
\end{tabular}

\footnotetext{
${ }^{1}$ Diversity indexes were calculated only for hosts from which at least ten isolates were obtained.

${ }^{2}$ Hosts with the same letter did not differ significantly in terms of Botryosphaeriaceae species composition at the $\alpha=0.05$ significance level using LSD test.
} 


\subsection{Inoculations of stems and leaves of seedlings in the field}

Botryosphaeria dothidea and P. cupressi formed cankers when inoculated onto C. lawsoniana seedlings, and $P$. cupressi was more aggressive. In contrast, C. lawsoniana seedlings inoculated with $B$. dothidea isolate from $C$. lawsoniana from the $\mathrm{CR}$ and five other Botryosphaeriaceae showed only resinous lesions that were not significantly different to that observed in the controls (Tables S5, S8, S15; Fig. S4). D. seriata produced girdling cankers with pycnidia of the fungus obvious on the canker surfaces when inoculated onto $Q$. robur, and the isolate from $C$. pisifera was more aggressive compared to that from Q. robur. N. parvumand B. dothidea produced resin-soaked girdling necrotic lesions when inoculated onto $P$. abies. Other disease symptoms were similar to those described by Zlatković et al. (2017). N. parvum isolated from C. lawsoniana was the most aggressive and it eventually killed the inoculated P. abies plants. B. dothidea and D. mutila produced girdling cankers and necrotic lesions when inoculated onto C. arizonica and B. dothidea isolated from C. lawsoniana grown in the MR was the most aggressive to this host. N. parvum was able to produce lesions and eventually kill inoculated P. nigra var. italica seedlings. The N. parvum isolate from S. giganteum was more aggressive to this host compared to the isolate from E. globulus. In contrast, $B$. dothidea did not produce lesions when inoculated into stems of $P$. nigra var. italica seedlings (Tables1, 4, S3, S8, S156; Figs. S4-S8).

Botryosphaeria dothidea, Do. omnivora and N. parvum killed S. giganteum plants 13 weeks after inoculation. Seedlings showed initial symptoms of shoot die-back one week after inoculation. Other symptoms included wilting and girdling stem lesions. Control plants remained asymptomatic. The B. dothidea isolate from $C$. lawsoniana grown in the CR and Do. omnivora had the highest AUDPC values and were shown to be the most aggressive. N. parvum isolated from E. globulus was the least aggressive. D. seriata and B. dothidea killed A. concolor seedlings 12-20 weeks post inoculation. Plants displayed symptoms and signs of yellowing and browning of the needles, stem die-back and needle cast followed by the appearance of $D$. seriata and $B$. dothidea pycnidia in the dead bark. B. dothidea was the most aggressive and D. seriata isolate from Q. robur was the least aggressive (Tables4, S3, S15; Figs. 2, 3, S9, S10).

Seedlings of $T$. occidentalis displayed initial symptoms of yellowing, browning, reddening of the leaves and shoot flagging seven weeks after inoculation with four Botryosphaeriaceae species. Other symptoms included dry, black and necrotic leaves, girdling lesions and fungal pycnidia in the dead tissues. Control plants remained asymptomatic. D. seriata, N. parvum isolated from E. globulus and B. dothidea isolated from C. lawsoniana grown in the CR were the most aggressive species. D. mutila, D. seriata and B. dothidea were able to kill C. sempervirens. 
Table 4. Pathogenicity of Botryosphaeriaceae species on various hosts in this and in previous studies in the Western Bakans (Zlatković et al. 2016b, 2017).

\begin{tabular}{|c|c|c|c|c|c|c|c|c|c|c|}
\hline \multirow{2}{*}{ Host } & \multicolumn{10}{|c|}{ Botryosphaeriaceae species } \\
\hline & $\begin{array}{c}\text { Botryosphaeria } \\
\text { dothidea }\end{array}$ & $\begin{array}{c}\text { Neofusicoccum } \\
\text { parvum }\end{array}$ & $\begin{array}{c}\text { Diplodia } \\
\text { seriata }\end{array}$ & D. mutila & D. sapinea ${ }^{13}$ & $\begin{array}{c}\text { Dothiorella } \\
\text { sarmentorum }\end{array}$ & $\begin{array}{c}\text { Do. } \\
\text { omnivora }\end{array}$ & Dothiorella sp. & $\begin{array}{c}\text { Phaeobotryon } \\
\text { cupressi }\end{array}$ & $\begin{array}{c}\text { Sphaeropsis } \\
\text { visci }\end{array}$ \\
\hline $\begin{array}{l}\text { Chamaecyparis } \\
\text { lawsoniana }\end{array}$ & $-5 /+^{6}$ & - & - & - & - & - & - & - & + & - \\
\hline Cedrus atlantica & - & $+{ }^{7} /-^{8}$ & - & - & - & - & & - & & \\
\hline C. deodara & & -7 & & & - & & & & & \\
\hline $\begin{array}{l}\text { Prunus } \\
\text { laurocerasus }\end{array}$ & & $++^{1,7,8} /+^{7,8}$ & & $\begin{array}{l}-1,11 /+ \\
1,12 /+7,8,11\end{array}$ & - & & & & & \\
\hline $\begin{array}{l}\text { Sequoiadendron } \\
\text { giganteum }\end{array}$ & + & + & & & & & + & & & \\
\hline $\begin{array}{l}\text { Thuja } \\
\text { occidentalis }\end{array}$ & + & + & + & & - & + & & & & \\
\hline $\begin{array}{l}\text { Pseudotsuga } \\
\text { menziesii }\end{array}$ & - & & & & + & & & & & \\
\hline Abies concolor & + & & + & & + & & & & & \\
\hline $\begin{array}{l}\text { Juniperus } \\
\text { horizontalis }\end{array}$ & + & & & & + & & & & & \\
\hline Cupressus arizonica & + & & & + & & & & & & \\
\hline $\begin{array}{l}\text { Liriodendron } \\
\text { tulipifera }\end{array}$ & + & & & & & & & & & \\
\hline $\begin{array}{l}\text { Magnolia } \\
\text { grandifolia }\end{array}$ & + & & & & & & & & & \\
\hline $\begin{array}{l}\text { Ligustrum } \\
\text { vulgare }\end{array}$ & & & + & & & & & & & \\
\hline C. sempervirens & + & & + & + & & & - & & - & \\
\hline Picea omorika & & $+{ }^{7}$ & & & & & & & & \\
\hline Quercus robur & & & + & & & & & & & \\
\hline $\begin{array}{l}\text { Pittosporum } \\
\text { tobira }\end{array}$ & & + & & - & & & & & & \\
\hline $\begin{array}{l}\text { Aesculus } \\
\text { hippocastanum }{ }^{2}\end{array}$ & + & + & & + & & + & & & & \\
\hline Pinus patula ${ }^{3}$ & + & + & & & + & & & & & \\
\hline Eucalyptus grandis ${ }^{3}$ & + & + & & & - & & & & & \\
\hline P. abies & + & + & & & + & & & & & \\
\hline P. pungens & & & & & + & & & & & \\
\hline
\end{tabular}




\section{Table 4. Continued.}

\begin{tabular}{|c|c|c|c|c|c|c|c|c|c|c|}
\hline \multirow{2}{*}{ Host } & \multicolumn{10}{|c|}{ Botryosphaeriaceae species } \\
\hline & $\begin{array}{c}\text { Botryosphaeria } \\
\text { dothidea }\end{array}$ & $\begin{array}{c}\text { Neofusicoccum } \\
\text { parvum }\end{array}$ & $\begin{array}{c}\text { Diplodia } \\
\text { seriata }\end{array}$ & D. mutila & D. sapinea & $\begin{array}{c}\text { Dothiorella } \\
\text { sarmentorum }\end{array}$ & Do. omnivora & Dothiorella sp. & $\begin{array}{c}\text { Phaeobotryon } \\
\text { cupressi }\end{array}$ & $\begin{array}{c}\text { Sphaeropsis } \\
\text { visci }\end{array}$ \\
\hline P. nigra & & & & & + & & & & & \\
\hline P. sylvestris & & & & & + & & & & & \\
\hline F. sylvatica ${ }^{2}$ & & & & & + & & & & & \\
\hline Viscum album $^{2,4}$ & & & & & & & & & & + \\
\hline Populus tremula ${ }^{2}$ & + & & & & & & & & & \\
\hline Fraxinus excelsior $^{2}$ & & & $+{ }^{9} /-{ }^{10}$ & & & & - & & & \\
\hline Forsythia europaea & & & & & & - & & & & \\
\hline Quercus cerris $^{2}$ & + & & & & & & & & & \\
\hline Taxus baccata & - & & & & & & & & & \\
\hline Prunus cerasus & & & - & & & & & & & \\
\hline P. nigra var. italica & - & + & & & & & & & & \\
\hline Quercus rubra & & - & - & & & - & & & & \\
\hline Platanus acerifolia & - & & & & & & & & & \\
\hline
\end{tabular}




\section{AUDPC}

- B. dothidea CMW39315

ㄷ B. dothidea CMW39301

- Do. omnivora CMW39361

* Do. omnivora CMW 39363

- N.parvum CMW 39327

$\rightarrow$ N.parvum CMW 39317 $580^{\mathrm{a}} *$

$720^{\mathrm{b}}$

$810^{\mathrm{b}}$

$750^{\mathrm{b}}$

$605^{\mathrm{a}}$

$230^{\mathrm{c}}$

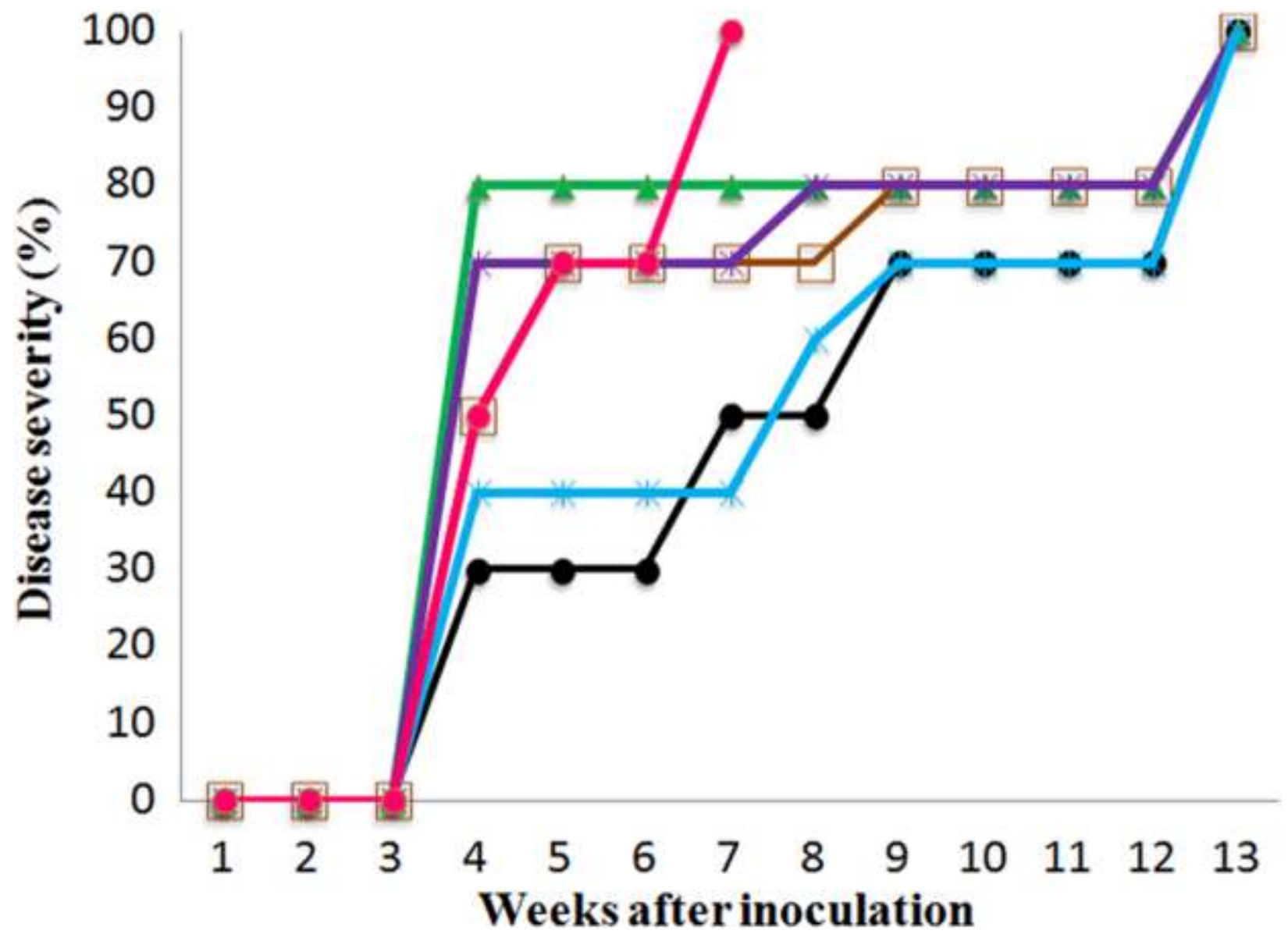

Figure 2. Disease progress curves and Area Under the Disease Progress Curve (AUDPC) of seedlings of Sequoiadendron giganteum inoculated with Botryosphaeria dothidea, Dothiorella omnivora and Neofusicoccum parvum. The ANOVA test indicated that there were significant differences in AUDPC values of seedlings of $S$. giganteum at $\alpha=0.05$ level $(\mathrm{F}=70.57, \mathrm{df}=2$, $\mathrm{p}=0.03$ ). Means with the same letter did not differ significantly, as determined by the LSD test at $\alpha=0.05$ level. " **، indicates that AUDPC values of isolates of the same species were significantly different (z-test, B. dothidea: $\mathrm{z}=3.89, \mathrm{p}=0.0001 ; N$. parvum: $\mathrm{z}=$ $12.98, \mathrm{p}<0.00001)$. 


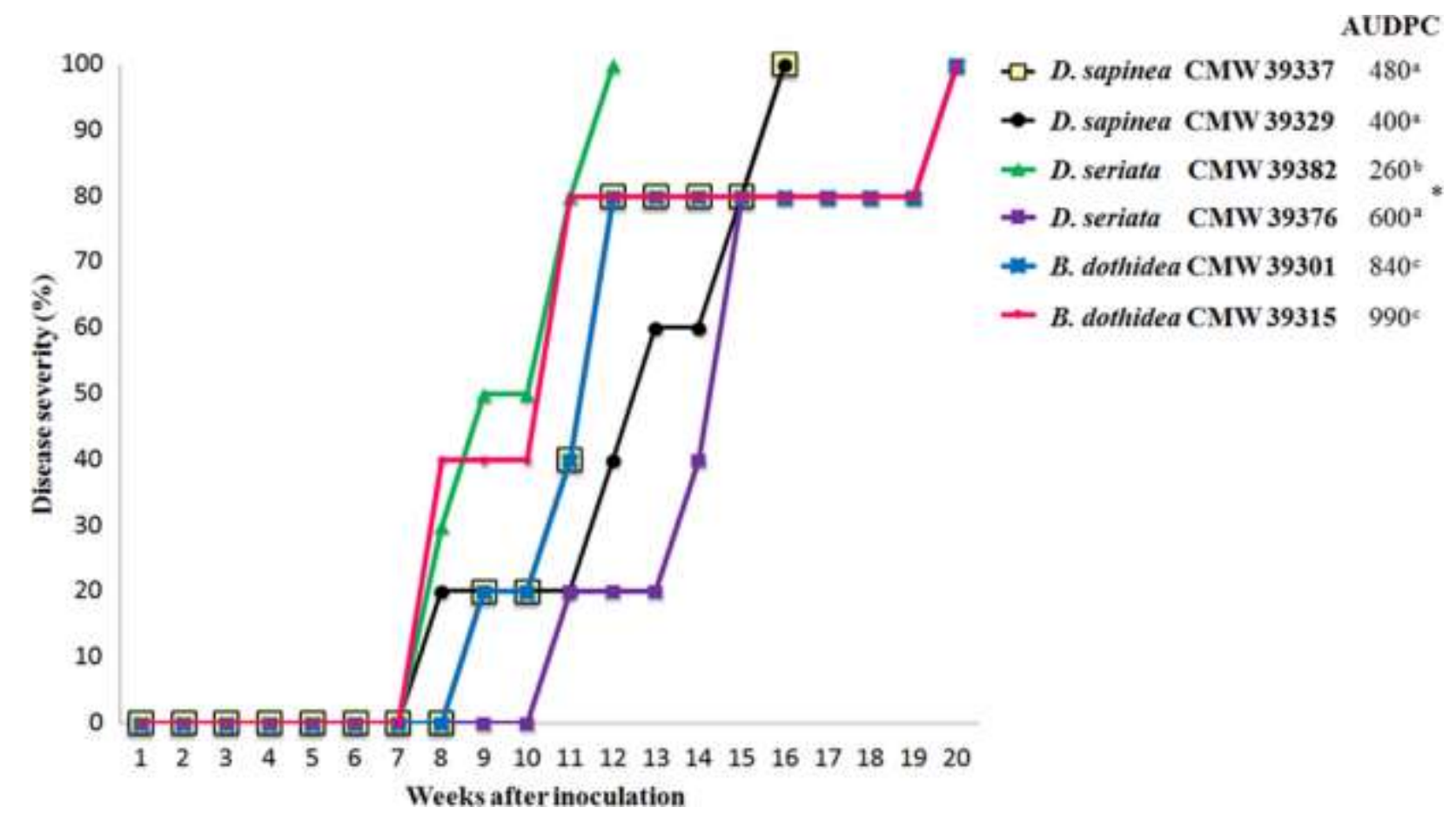

Figure 3. Disease progress curves and Area Under the Disease Progress Curve (AUDPC) of seedlings of Abies concolor inoculated with Diplodia sapinea, D. seriata and Botryosphaeria dothidea. The ANOVA test indicated that there were significant differences in AUDPC values of seedlings of $A$. concolor at $\alpha=0.05$ level $(F=19.9, d f=2, p=0.02)$. Means with the same letter did not differ significantly, as determined by the LSD test at $\alpha=0.05$ level. "** indicates that AUDPC values of isolates of the same species were significantly different (z-test, D. seriata: $\mathrm{z}=11.58, \mathrm{p}<0.0001$ ). Data for Diplodia sapinea were retrieved from Zlatković et al. 2017 and serve for comparison with other Botryosphaeriaceae inoculated onto A. concolor.

Seedlings displayed the first symptoms of shoot flagging two weeks after inoculation and later exhibited die-back of stems, yellowing of the needles and needle drying. Disease symptoms were not observed on seedlings inoculated with $P$. cupressi, Do. omnivora or on the controls. N. parvum was able to kill P. omorika. Disease symptoms were similar to those described in Zlatković et al. (2017) and controls remained healthy (Tables1,4; S3, Figs. 4-6, S11S13).

Diplodia seriata was shown to produce vascular discoloration when inoculated onto $L$. vulgare and $B$. dothidea produced vascular discoloration on M. grandifolia. B. dothidea produced necrotic lesions when inoculated onto L. tulipifera and an isolate from C. lawsoniana grown in the CR was more aggressive compared to an isolate from the same host grown in the MR. In contrast, $B$. dothidea did not cause lesions on seedlings of $P$. menziesii and $N$. parvum did not cause lesions on seedlings of $C$. deodara. $N$. parvum isolated from $S$. giganteum produced sunken, girdling cankers on stems of C. atlantica. Other Botryosphaeriaceae and the controls produced only small resinous lesions. B. dothidea produced necrotic lesions on stems of J. horizontalis. Do. sarmentorum did not 


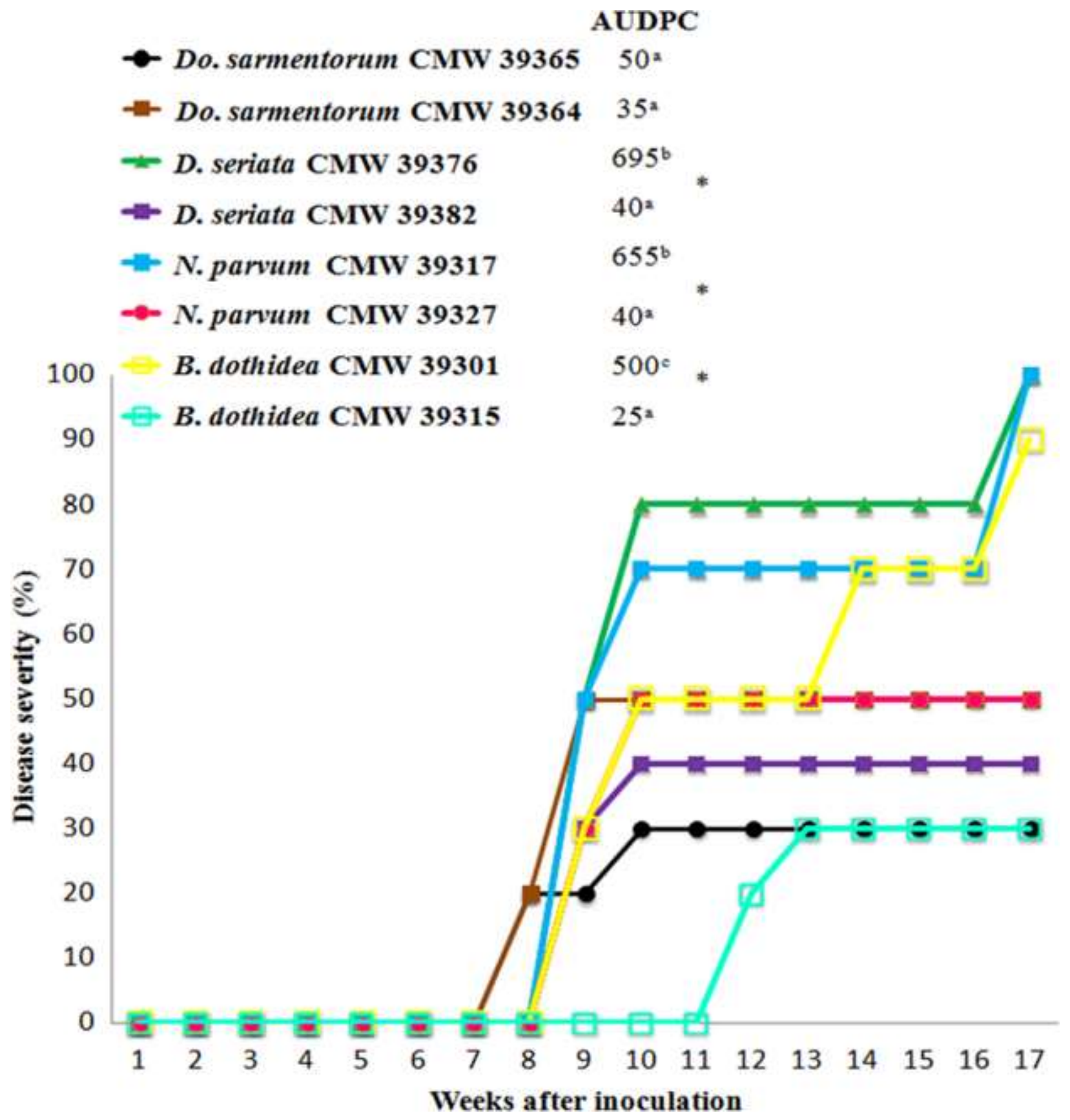

Figure 4. Disease progress curves and Area Under the Disease Progress Curve (AUDPC) of seedlings of Thuja occidentalis inoculated with Diplodia seriata, Neofusicoccum parvum and Botryosphaeria dothidea. The ANOVA test indicated that there were significant differences in AUDPC values of seedlings of $T$. occidentalis at $\alpha=0.05$ level $(\mathrm{F}=913.15, \mathrm{df}=3, \mathrm{p}=0.000004)$. Means with the same letter did not differ significantly, as determined by the LSD test at $\alpha=0.05$ level. "** indicates that AUDPC values of isolates of the same species were significantly different (z-test, D. seriata: $\mathrm{z}=24.16, \mathrm{p}<0.00001 ;$. parvum: $\mathrm{z}=23.33$, $\mathrm{p}<0.00001 ;$ B. dothidea: $\mathrm{z}=20.73$, $\mathrm{p}<0.00001)$. 


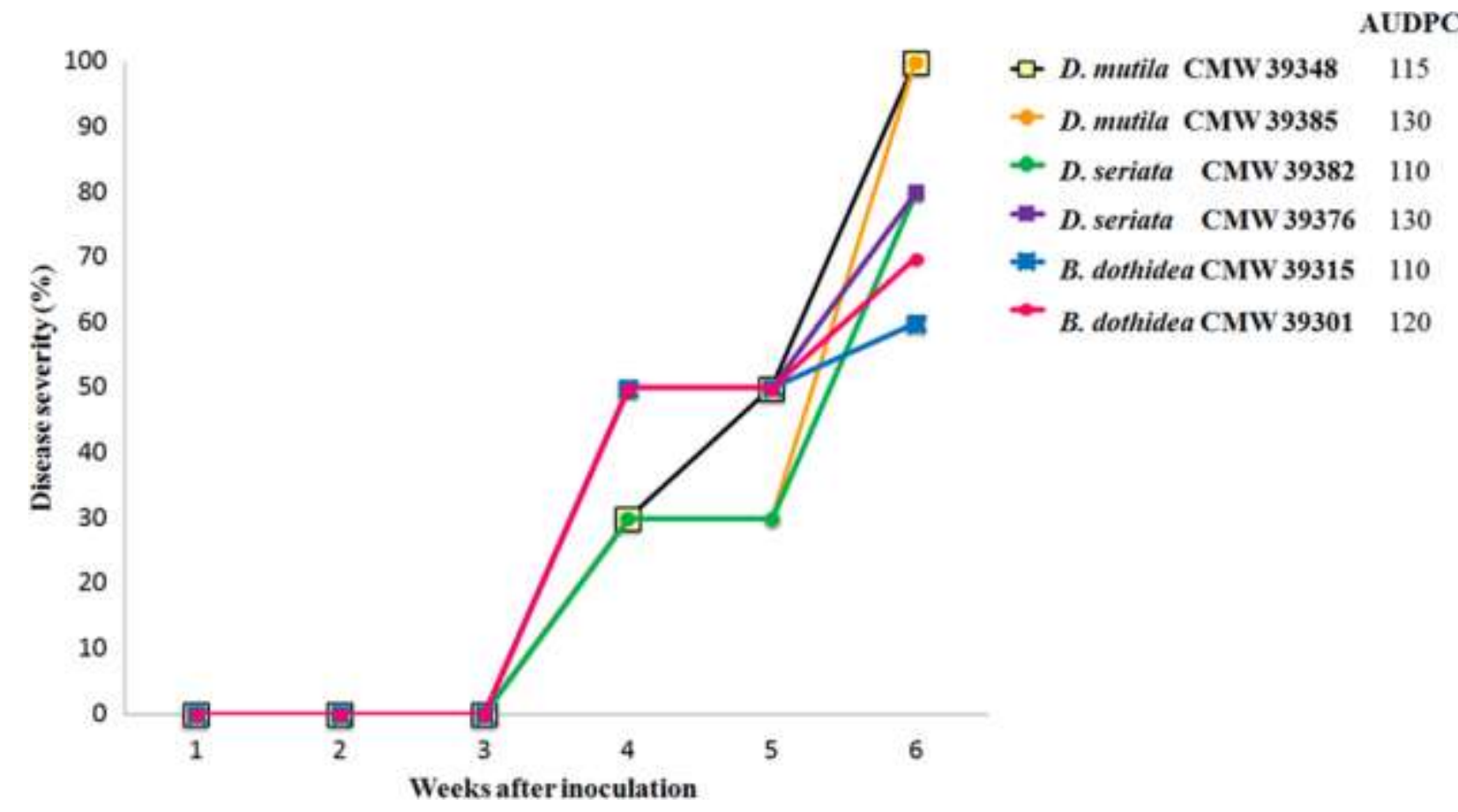

Figure 5. Disease progress curves and Area Under the Disease Progress Curve (AUDPC) of seedlings of Cupressus sempervirens inoculated with Diplodia mutila, D. seriata and Botryosphaeria dothidea. The ANOVA test indicated that there were no significant differences in AUDPC values of seedlings of $C$. sempervirens at $\alpha=0.05$ level $(F=5.97, d f=1, p=0.07)$.

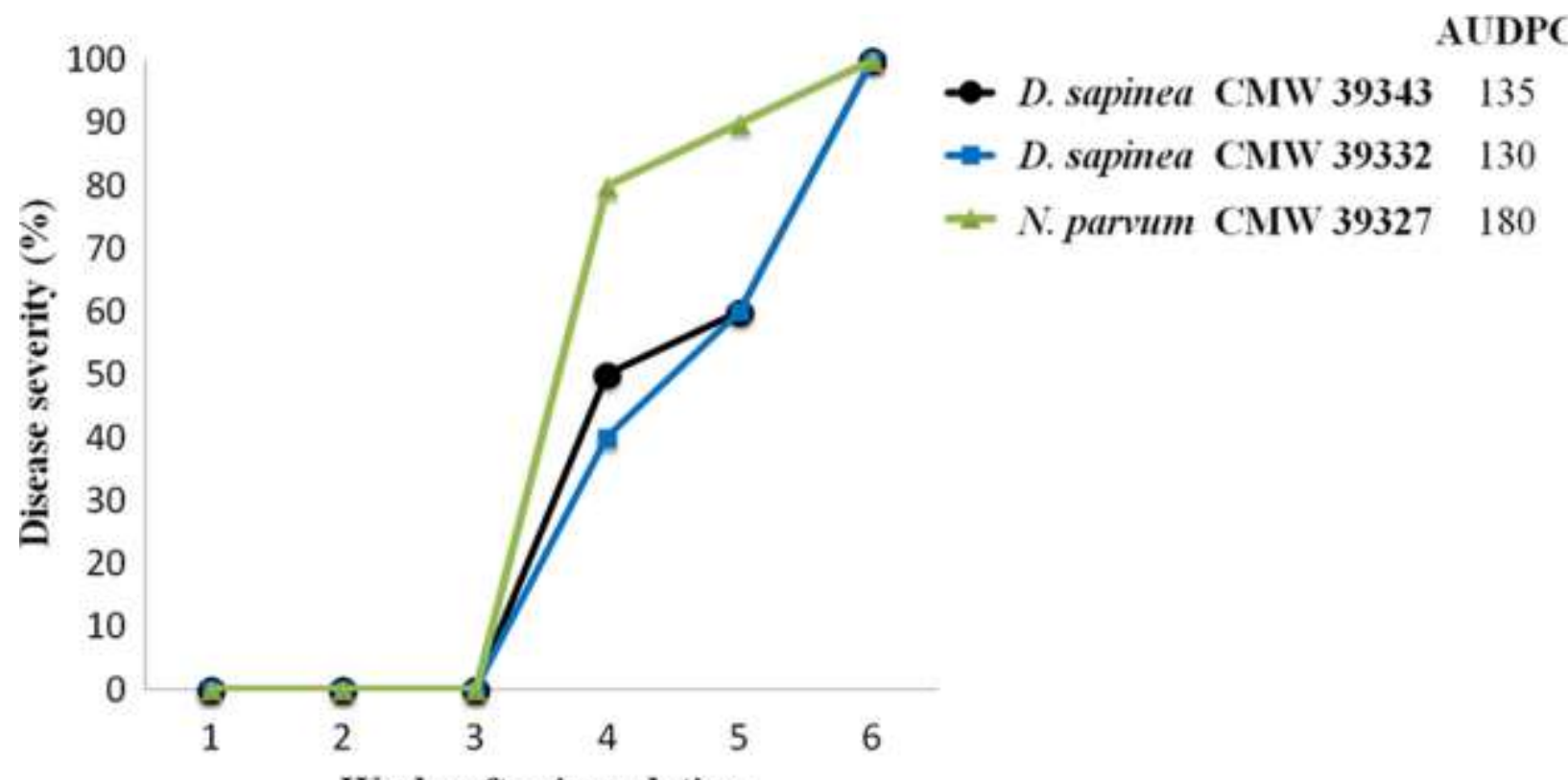

\section{Weeks after inoculation}

Figure 6. Disease progress curves and Area Under the Disease Progress Curve (AUDPC) of seedlings of Picea omorika inoculated with Diplodia sapinea and Neofusicoccum parvum. The t-test indicated that there were no significant differences in AUDPC values of seedlings of $P$. omorika at $\alpha=0.05$ level $(\mathrm{t}=-10.97, \mathrm{df}=1, \mathrm{p}=0.06)$. Data for Diplodia sapinea were retrieved from Zlatković et al. 2017 and serve for comparison with other Botryosphaeriaceae inoculated onto P. omorika. 
produce lesions on seedlings of F. europaea; D. seriata, Do. sarmentorum and N. parvum did not produce lesions on Q. rubra; B. dothidea did not produce lesions on P. acerifolia and T. baccata, and D. seriata did not produce lesions on $P$. cerasus. $N$. parvum produced dark brown elongated lesions on stems of $P$. tobira. Isolates of $D$. mutila and control plants displayed no lesions. N. parvum and D. mutila isolated from C. sempervirens produced reddish-brown elliptical cankers with cracks inside the canker and along the canker margin on stems of P. laurocerasus seedlings. In contrast, P. laurocerasus seedelings inoculated with $D$. mutila isolated from $T$. plicata showed only dark brown lesions visible after the outer bark was removed and these lesions were not significantly larger from those produced on the controls.

Leaves of $P$. laurocerasus showed necrotic lesions five days after inoculation. N. parvum isolated from $E$. globulus was the most aggressive fungus. No lesions appeared on leaves of the control plants and plants inoculated with D. mutila isolated from T. plicata (Zlatković et al. 2016b; Tables 1, S3, S8; Fig. S22). Botryosphaeriaceae were re-isolated and identified from symptomatic tissues of all inoculated stems and leaves of seedlings. Exceptions were resinous lesions formed on C. lawsoniana and C. atlantica, brown lesions fomed on P. laurocerasus after inoculation with D. mutila isolate from T. plicata, seedlings which were inoculated with Botryosphaeriaceae isolates but did not show lesions, and controls (Tables4, S3, S8, S15; Figs. S14-S182).

\subsection{Inoculations of cut branches and leaves of cut branches}

Botryosphaeria dothidea, D. mutila isolated from C. sempervirens, Do. sarmentorum isolated from C. lawsoniana and $N$. parvum were the most aggressive species when inoculated onto A. hippocastanum branches. Do. sarmentorum isolate from $T$. occidentalis was the least aggressive. B. dothidea produced brown, girdling lesions when inoculated onto P. tremula branches and brown, elongated lesions when inoculated onto Q. cerris branches. Control branches produced no lesions. D. seriata isolated from C. pisifera produced brown, elliptical lesions with pycnidia formed in lesions when inoculated onto F. excelsior branches. Control branches, branches inoculated with D. seriata from Q. robur and with Do. omnivora showed no lesions. V. album shrubs showed necrotic lesions on branches and leaves five days after inoculation. Two weeks post inoculation, branches and leaves appeared chlorotic; branches were girdled and S. visci pycnidia were found embedded in the dead tissues. Control branches and leaves showed only minimal discoloration around the wounds (Tables1, S3, S8, S15; Figs. S19-S21). Re- 
isolations from fungal pycnidia and discoloured tissues were successful and Koch's postulates were fulfilled in both pathogenicity tests conducted on cut branches and leaves of cut branches.

\subsection{Inoculations of stems of seedlings in the greenhouse}

B. dothidea was less aggressive compared to N. parvum when inoculated onto P. patula. N. parvum isolated from $E$. globulus was the most aggressive and the $B$. dothidea from CR was the least aggressive when inoculated onto $E$. grandis. In contrast, seedlings of $E$. grandis inoculated with $B$. dothidea isolate from MR showed lesions that did not differ obviously from those produced on the controls. Lesions formed on control seedlings were significantly smaller compared to those produced by Botryosphaeriaceae species (Tables4, S3; S8, S15, Figs. S23-24). Botryosphaeriaceae were successfully re-isolated and identified from all seedlings other than from the controls.

\section{Discussion}

In this study, six Botryosphaeriaceae species (B. dothidea, N. parvum, D. mutila, D. seriata, Do. sarmentorum, Do. omnivora,) were identified from 30 tree species and five shrubby species growing in urban areas, forests and ornamental nurseries. An additional four Botryosphaeriaceae species (D. sapinea, Dothiorella sp., P. cupressi and $S$. visci) were obtained in previous studies (Zlatković et al., 2016a, b, 2017), giving a total of ten Botryosphaeriaceae isolated from 47 tree and shrubby species in urban areas, forest plantations, forests and ornamental nurseries in the Western Balkans region. P. cupressi and S. visci occurred on only a single host, but Dothiorella sp. was found on two hosts and the remaining Botryosphaeriaceae were associated with more than four hosts. Botryosphaeriaceae were mostly pathogenic to the hosts from which they were isolated, but were also able to infect other tree species. The results of this study, based on a high number of hosts and the ability of Botryosphaeriaceae to infect both host and non-host species, illustrate the generalist nature of most of the species.

Very few Botryosphaeriaceae species appear to be host specific. The association of $S$. visci with only hemiparasitic V. album shrubs could be interpreted as host specificity. Other than this study, S. visci has been isolated only from V. album (Phillips et al., 2013; Zlatković et al., 2016a). Furthermore, Varga et al. (2011) showed that $S$. visci causes disease in V. album. P. cupressi was found only on C. sempervirens in this study, but has previously also been isolated from J. scopulorum, both of which are Cupressaceae (Phillips et al., 2013). In our inoculation experiments, $P$. cupressi was able to infect $C$. lawsoniana, and it gave rise to large lesions. In contrast, $P$. cupressi 
did not cause lesions on inoculated $C$. sempervirens. This is possibly because $P$. cupressi was isolated as an endophyte from healthy tissues of $C$. sempervirens in the current study and previously by Abdollahzadeh et al. (2009).. Dothiorella sp. was also isolated from a limited number of hosts in this study, namely from $T$. plicata and C. atlantica. This fungus appears to display some patterns of host preference as it was not able to cause lesions on $C$. lawsoniana despite its having been found on $C$. atlantica, on which it occurs as an endophyte.

Botryosphaeria dothidea and N. parvum are known to have a broad host range (Sakalidis et al., 2013; Marsberg et al., 2017). In the present study, B. dothidea occurred on the greatest number (22) of hosts and was shown to cause lesions on many of them. Isolations and inoculation experiments showed that this fungus is a significant pathogen of ornamental trees and shrubs. Apart from producing cankers on the inoculated seedlings and lesions on the inoculated branches, the pathogen was able to kill S. giganteum, T. occidentalis, A. concolor, P. abies plants and to girdle branches of A. hippocastanum. B. dothidea was also able to infect P. patula and E. grandis from which it was not isolated and lesions produced on $P$. patula were significanly smaller than those caused by $N$. parvum. Similarly, in a study by Pavlic et al. (2007), B. dothidea isolated from native Syzigium cordatum produced lesions on E. grandis from which it has not been isolated and it was less aggressive compared to N. parvum. Neofusicoccum parvum is an important pathogen of Eucalyptus spp. (Slippers et al., 2009) and its aggressiveness on this tree in the present study is thus not surprising. N. parvum is also a pathogen of ornamental trees and shrubs (e.g. Begoude et al., 2010; Varela et al., 2011) and in the present study was shown to infect eight ornamental tree species. N. parvum was isolated from 16 hosts and these included ten gymnosperms and six angiosperms. Similarly, Sakalidis et al. (2013) showed a lack of host specifity for this fungus and argued that the ability of N. parvum to exist as an endophyte in asymptomatic plants and to colonize a wide range of hosts could explain its wide distribution in many countries and continents. This is also consistent with the view that the endophytic nature of fungi such as the Botryosphaeriaceae implies that they are easily overlooked by quarantine systems (Wingfiled et al., 2015; Burgess and Wingfield, 2017; Crous et al., 2016).

The majority of the Botryosphaeriaceae species (seven of 10) from the Western Balkans identified in this and in previous studies (Zlatković et al. 2016a, b, 2017) were isolated from multiple tree species and numerous new host associations have been established. This is not surprising for Botryosphaeriaceae species such as the previously mentioned B. dothidea and $N$. parvum, which are known to occur on a large number of different tree species (Sakalidis et al., 2013; Marsberg et al., 2017). However, the previous study showed that the host range of the pine 
pathogen D. sapinea was unexpectedly broad and the species was isolated from 16 tree and shrub species (Zlatković et al. 2017).

In this study, Botryosphaeriaceae species were shown to infect tree species having important ecological and cultural value. This adds to the threat many of these trees face already. For example, it was shown that $B$. dothidea, D. seriata and D. mutila contribute to the die-back of $C$. sempervirens, a valuable ornamental tree that is regarded as key element of the Mediterranean scenery (Xenopoulos et al., 1990). The "cypress canker" disease caused by Seiridium spp. is known as one of the most serious threats to the survival of C. sempervirens (Graniti, 1998; Danti et al., 2014) and this study adds to the understanding that there are other fungi involved in the die-back of this tree. Similarly, $N$. parvum wasable to infect and kill $P$. omorika, an endemic tree that is in danger of extinction due to its limited population distribution, loss of genetic diversity and the effects of climate change (Alberto et al., 2013). Likewise, multiple Botryosphaeriaceae species were shown to infect A. hippocastanum, an endemic tree threatened by the leaf-mining moth Cameraria ohridella (Stojanović and Marković, 2004; Valade et al., 2009).

Various Botryosphaeriaceae found in this study were able to kill tree species that are economically valuable. For example, D. seriata was able to infect and eventually kill $Q$. robur, which is an economically valuable tree that is threatened by a change of flood regime and climate in northern Serbia (Stojanović et al., 2015). $D$. seriata was able to produce lesions on $F$. excelsior branches. $F$. excelsior has been devastated by the fungal pathogen Hymenoscyphus fraxineus in many parts of Europe, including parts of the Western Balkans (Pautasso et al., 2013; Stanivuković et al., 2014; Keča et al., 2017; Milenković et al., 2017) and this study shows that $D$. seriata might be also contributing to the impact of ash die-back disease.

The results from this study showed that an individual isolate of the Botryosphaeriaceae species has the potential for a wide range of aggressiveness to various often phylogenetically unrelated hosts. However, inoculations were carried out under partially controlled conditions on plants in the field and on cut branches; the level of plant stress was not measured. Botryosphaeriaceae are known as opportunistic pathogens capable of causing disease in a stressed host (Slippers and Wingfield 2007). Thus the aggressiveness of these fungi might have been higher than it would have been under completely controlled conditions or using living plants instead of plant parts. Moreover, a large amount of inoculum supplied with nutrients in the agar plug was placed on a wound, and in contact with vascular tissues. Although this method has been considered to represent the natural mode of infection 
of these fungi, it would be likely that under such conditions even an opportunistic pathogen could cause the disease (Manawashinge et al. 2016) .

Multiple Botryosphaeriaceae species were commonly isolated from the same host species, trees or even the same lesions. Similarly, in a study by Pavlic et al. (2008) eight Botryosphaeriaceae were isolated from asymptomatic tissues of the native S. cordatum plants and many species were obtained from the same plant. Luchi et al. (2013) reported a complex process of colonization of eight conifer species in Italy, where eleven Botryosphaeriaceae were found in symptomatic and asymptomatic tissues. Likewise, Jami et al. (2014) found no evidence that Botryosphaeriaceae species were tissue specific. Results of the pathogenicity tests in the present study showed that Botryosphaeriaceae isolated from the same host might play different roles in the process of tree die-back. For example, seven species were isolated from C. atlantica and C. lawsoniana, but of these only a single strain of $N$. parvum and $B$. dothidea was able to cause disease symptoms on these hosts. However, given the opportunistic nature of Botryosphaeriaceae species and predicted more frequent extreme weather events in the Western Balkans (www.hidmet.gov.rs, accessed October 2017) the possibility of currently non-pathogenic Botryospaheriaceae becoming pathogenic to the particular host should not be neglected.

The results of this study confirm that the distribution of Botryosphaeriaceae is influenced by the host (Burgess et al., 2005; Slippers and Wingfield, 2007; Fabre et al., 2011; Jami et al., 2014). Host factors might have influenced the distribution of $S$. visci because shrubs of V. album grow only in the CR. In contrast, Do. sarmentorum and Dothiorella sp. were not isolated from the MR even though its hosts, C. lawsoniana and C. atlantica, are widely planted in both areas. Similarly, Burgess et al. (2006) showed that N. australe is prevalent in Western Australia, but can rarely be found in Eastern Australia, even though its Eucalyptus host is present in both areas. P. cupressi was found only in the MR where its host, $C$. sempervirens is native although this tree is also occasionally planted in the CR. Differences in host genetics and presence of both native and introduced trees could explain the different Botryosphaeriaceae community structures on this tree.

Diversity analyses from this study showed no significant differences in the Botryosphaeriaceae species diversity in the CR compared to the MR. This was surprising as previous studies showed that Botryosphaeriaceae species diversity and occurrences are also influenced by the environment in which the given host occurs (Slippers and Wingfield, 2007; Fabre et al., 2011). However, no general conclusions can be made based on the current data 
regarding the differences in Botryosphaeriaceae species distributions because the number of samples from the MR was unduly limited.

The die-back of trees sampled in this study could be associated with some form of stress to trees linked to either recent extreme weather patterns, a "heat island effect", other stresses affecting trees in the cities, or planting of species on suboptimal sites (Allen et al., 2010; Zlatković et al., 2016a, 2017). P. abies sampled in this study also occur at the edge of its southern range, which might imply stress symptoms. Furthermore, the shallow-rooted $P$. abies is vulnerable to drought, which is already causing mortality of this tree in Central and Northern Europe. Similarly, $C$. atlantica is experiencing mass mortality in its native range in North Africa linked to climate change (Allen et al., 2010). In addition, a number of forest management practices might have contributed stress on these trees. For example, ornamental trees in Serbia are frequently propagated from locally collected seeds in urban areas of unknown provenance (www.minpolj.gov.rs), and that have not been adequately tested for planting in given environments. Also, P. laurocerasus is a shade demanding species, but in the cities of Serbia these shrubs are frequently planted on open spaces.

In urban areas, exotic tree species are planted close to native species that could provide a source of inoculum for cross infection to occur. The results of the inoculation tests confirmed that Botryosphaeriaceae isolated from introduced trees can infect native trees and vice versa. It also shows that Botryosphaeriaceae can move from ornamental to forest trees and vice versa. For example, isolates of $B$. dothidea from C. lawsoniana were able to infect seedlings of native P. abies. Similarly, close proximity of native and exotic species was hypothesized to be the reason for the occurrence of $N$. eucalyptorum, a pathogen of Eucalyptus spp. on native myrtaceous hosts in Uruguay (Perez et al., 2010) and for the infection of Eucalyptus plantations established close to the native vegetation in South Africa (Burgess and Wingfield, 2001; Pavlic et al., 2007). D. seriata is a well-known pathogen of fruit trees (Slippers et al., 2007), however, in this study, isolates of D. seriata from C. pisifera and Q. robur were not able to produce lesions on $P$. cerasus, but could produce lesions or infect and eventually kill four ornamental and two forest tree species. Population genetic analyses are needed to test the gene flow between populations of $D$. seriata on fruit, ornamental and forest trees as has recently been shown by Mehl et al. (2017).

The Botryosphaeriaceae were most diverse on gymnosperms in this study. With the exception of $A$. hippocastanum and S. caprea, which harbored four and three Botryosphaeriaceae respectively, all other angiosperms harbored one or two species. This is surprising and in contrast to the results of most previous studies. For example, 
previous authors (De Wet et al., 2008; Sakalidis et al., 2013; Slippers et al., 2013), the Botryosphaeriaceae are most common and diverse on angiosperms. In contrast, Alves et al. (2013) reported great diversity of these species associated with conifers in Portugal, but conifers were the only trees sampled in the study and no comparison with the diversity on angiosperms was made. It is difficult to explain these patterns because sampling, host diversity, climate and other factors are not consistent across these studies. Overall, however, the results show that both gymnosperms and angiosperms can harbor substantial Botryosphaeriaceae diversity in different environments and circumstances.

This study has demonstrated that various trees and shrubs in the Western Balkans harbor a wide diversity of Botryosphaeriaceae, and with the exception of $S$. visci on V. album, most have broad host ranges. However, some Botryosphaeriaceae species appeared to occur predominantly on certain hosts and this suggests that those tree species posses some characteristics favorable for these fungi. The fact that some Botryosphaeriaceae were able to cross-infect taxonomically unrelated trees and eventually kill the plants emphasizes the importance of this fungal group. There is clearly a need for further research considering the pathways of introduction and spread of these fungi (Slippers et al., 2017) as well as methods (Crous et al., 2016) to understand and manage the diseases with which they are associated.

\section{Acknowledgements}

We thank members of Tree Protection Co-operative Programme (TPCP), the University of Pretoria, South Africa and the Ministry of Education, Science and Technological Development of the Republic of Serbia (TR37008 and III43007) for the financial support that made this study possible. The first author also wishes to acknowledge partial financial support from European Cooperation in Science and Technology (COST) Actions Pathway Evaluation in Pest Risk Management In Transport (PERMIT FP1002), ALIEN Challenge (TD1209) and A global network of nurseries as early warning system against alien tree pests (Global Warning FP1401). Nursery of the Faculty of Forestry (University of Belgrade) is acknowledged for providing some of the seedlings used in the pathogenicity trials. Dr. Jelena Lazarević is thanked for help with sampling in Montenegro and Profs. Nenad Keča and Dragan Karadžić and Dr. Slobodan Milanović for providing some of the samples used in this study. 


\section{References}

Abdollahzadeh, J., Goltapeh, E.M., Javadi, A., Shams-Bakhsh, M., Zare, R.; Phillips, A.J.L. (2009). Barriopsis iraniana and Phaeobotryon cupressi: two new species of the Botryosphaeriaceae from trees in Iran. Persoonia, 23, 1-8.

Allen, C. D., Macalady, A. K., Chenchouni, H., Bachelet, D., McDowel, N., Vennetier, M., Kitzberger, T., Rigling, A., Breshears, D.D., Hogg, E.H. (2010). A global overview of drought and heat-induced tree mortality reveals emerging climate change risks for forests. Forest Ecology and Management, 259, 660-684.

Alves, A., Barradas, C., Phillips, A.J.L., Correia, A. (2013). Diversity of Botryosphaeriaceae species associated with conifers in Portugal. European Journal of Plant Pathology, 135, 791-804.

Alves, A., Linaldeddu, B.T., Deidda, A., Scanu, B., Phillips, A.J.L. (2014). The complex of Diplodia species associated with Fraxinus and some other woody hosts in Italy and Portugal. Fungal Diversity, 67, $143-156$.

Begoude, B.A.D., Slippers B., Wingfield M.J., Roux J. (2010). Botryosphaeriaceae associated with Terminalia catappa in Cameroon, South Africa and Madagascar. Mycological Progress, 9, 101-123.

Burgess, T. I., Barber, P. A., Hardy, G. S. J. (2005). Botryosphaeria spp. associated with eucalypts in Western Australia, including the description of Fusicoccum macroclavatum sp. nov. Australasian Plant Pathology, $34,557-567$.

Burgess, T. I., Wingfield, M. J. (2017). Pathogens on the Move: A 100-year global experiment with planted Eucalypts. BioScience, 67, 14-25.

Carbone, I., Kohn, L. M. (1999). A method for designing primer sets for speciation studies in filamentous ascomycetes. Mycologia, 91, 553-556.

Crous, P. W., Groenewald, J. Z., Slippers, B., Wingfield, M. J. (2016). Global food and fibre security threatened by current inefficiencies in fungal identification. Philosophical Transactions of the Royal Society B: Biological Sciences, DOI: 10.1098/rstb.2016.0024.

Danti, R., Barberini, S., Pecchioli, A., Di Lonardo, V., Della Rocca, G. (2014). The Epidemic spread of Seiridium cardinale on leyland cypress severely limits its use in the Mediterranean. Plant Disease 98, 1081-1087.

De Wet, J., Slippers, B., Preisig, O., Wingfield, B.D., Wingfield, M.J. (2008). Phylogeny of the Botryosphaeriaceae reveals patterns of host association. Molecular Phylogenetics and Evolution, 46, 116-126. 
Fabre, B., Piou, D., Desprez-Loustau, M., Marcais, B. (2011). Can the emergence of pine Diplodia shoot blight in France be explained by changes in pathogen pressure linked to climate change? Global Change Biology, $17,3218-3227$

Felsenstein, J. (1985). Confidence intervals on phylogenetics: an approach using bootstrap. Evolution, 39, 783-791.

Gardes, M., Bruns, T.D. (1993). ITS primers with enhanced specificity for basidiomycetes-application to the identification of mycorrhizae and rusts. Molecular Ecology, 2, 113-118.

Glass, N.L., Donaldson, G.C. (1995). Development of primer sets designed for use with the PCR to amplify conserved genes from filamentous ascomycetes. Applied Environmental Microbiology, 61, 1323-1330.

Guindon, S., Dufayard, J.F., Lefort, V., Anisimova, M., Hordijk, W., Gascuel, O. (2010). New algorithms and methods to estimate Maximum-Likelihood phylogenies: Assessing the performance of PhyML 3.0. Systematic Biology, 59, 307-321.

Graniti, A. (1998). Cypress canker: a pandemic in progress. Annual Review of Phytopathology, 36, 91-114.

Inderbitzin, P., Bostock, R.M., Trouillas, F.P., Michailides, T.J. (2010). A six locus phylogeny reveals high species diversity in Botryosphaeriaceae from California almond. Mycologia, 102, 1350-1368.

Jacobs, K., Bergdahl, D. R., Wingfield, M. J., Halik, S., Seifert, K. A., Bright, D. E., Wingfield, B. D. (2004). Leptographium wingfieldii introduced into North America and found associated with exotic Tomicus piniperda and native bark beetles. Mycological Research, 108, 411-418.

Jami, F., Slippers, B., Wingfield, M.J., Gryzenhout, M. (2014). Botryosphaeriaceae species overlap on four unrelated, native South African hosts. Fungal Biology, 118, 168-179.

Jami, F., Slippers, B., Wingfield, M. J., Loots, M. T., Gryzenhout, M. (2015). Temporal and spatial variation of Botryosphaeriaceae associated with Acacia karroo in South Africa. Fungal Ecology, 15, 51-62.

Jankovský, L., Palovćiková, D. (2003). Dieback of Austrian pine - the epidemic occurrence of Sphaeropsis sapinea in southern Moravia. Journal of Forest Science, 49, 389-394.

Kaliterna, J., Milicevic, T., Bencic, D., Duralija, B. (2013). First Report of Neofusicoccum parvum associated with grapevine trunk diseases in Croatia. Plant Disease, 97, 1656.

Kaliterna, J., Milicevic, T., Ivic, D., Bencic, D., Mesic, A. (2012). First report of Diplodia seriata as causal agent of olive dieback in Croatia. Plant Disease, 96, 290. 
Karadžić, D., Milijašević, T. (2008). The most important parasitic and saprophytic fungi in Austrian pine and Scots pine plantations in Serbia. Bulletin of the Faculty of Forestry, 97, 147-170 (in Serbian with English summary).

Keča, N., Kirisits, T, Audrious M. (2017). First report of the invasive ash dieback pathogen Hymenoscyphus fraxineus on Fraxinus excelsior and F. angustifolia in Serbia. Baltic Forestry, 23, 56-59.

Köppen, W. (1936). Das geographisca system der klimate. In W. Köppen \& G. Geiger (Eds.), Handbuch der klimatologie. Berlin: Gebrüder Borntraeger. p. 44.

Kumar, D.S.S., Hyde, K.D. (2004). Biodiversity and tissue-recurrence of endophytic fungi in Tripterygium wilfordii. Fungal Diversity, 17, 69-90.

Latinović, J., Mazzaglia, A., Latinović, N., Ivanović, M., Gleason, M.L. (2013). Resistance of olive cultivars to Botryosphaeria dothidea, causal agent of olive fruit rot in Montenegro. Crop Protection, 48, 35-40.

Linaldeddu, B.T., Scanu, B., Maddau, L., Franceschini, A. (2014). Diplodia corticola and Phytophthora cinnamomi: the main pathogens involved in holm oak decline on Caprera Island (Italy). Forest Pathology, 44, 191-200.

Luchi, N., Longa, O., Danti, R., Capretti, P., Maresi, G. (2014). Diplodia sapinea: the main fungal species involved in the colonization of pine shoots in Italy. Forest Pathology, 44, 372-381.

Madden, L. V., Hughes, G., van den Bosch, F. (2007). The Study of Plant Disease Epidemics, St. Paul, MN: APS Press.

Manawasinghe, I. S., Phillips, A. J. L., Hyde, K. D., Chethana, K. W. T., Zhang, W., Zhao, W. S., Yan J.Y., Li, X. H. (2016). Mycosphere Essays 14: Assessing the aggressiveness of plant pathogenic Botryosphaeriaceae. Mycosphere, 7, 883-892.

Marsberg, A., Kemler, M., Jami, F., Nagel, J. H., Postma-Smidt, A., Naidoo, S., Wingfield, M. J., Crous, P. W., Spatafora, J. W., Hesse, C. N., Robbertse, B., Slippers, B. (2017). Botryosphaeria dothidea: a latent pathogen of global importance to woody plant health. Molecular Plant Pathology 18: 477-488.

Mehl, J.W.M., Slippers, B., Roux, J., Wingfield, M.J. (2013). Cankers and other diseases caused by Botryosphaeriaceae. In P. Gonthier \& G. Nicolotti (ed). Infectious forest diseases, CAB International, pp. 298-317.

Mehl, J.W.M, Slippers, B., Roux, J., Wingfield, M. J. (2017). Overlap of latent pathogens in the Botryosphaeriaceae on a native and agricultural host. Fungal Biology, 121, 405-419. 
Milenković, I., Jung, T., Stanivuković, Z., Karadžić, D. (2017). First report of Hymenoscyphus fraxineus on Fraxinus excelsior in Montenegro. Forest Pathology, DOI: 10.1111/efp.12359, in press.

Möller, E. M., Bahnweg, G., Sandermann, H., Geiger, H. H. (1992). A simple and efficient protocol for isolation of high molecular weight DNA from filamentous fungi, fruit bodies, and infected plant tissues. Nucleic Acids Research, 20, 6115-6116.

Oksanen, J., Blanchet, F.G., Kindt, R., Legendre, P., Minchin, P.R., O'Hara, R.B., Simpson, G.L., Solymos, P., Henry, M., Stevens, H., Wagner, H. (2015). Vegan: Community Ecology Package. R package version 2.21. http://CRAN.R-project.org/package=vegan.

Pautasso, M., Aas, G., Queloz, V., Holdenrieder, O. (2013). European ash (Fraxinus excelsior) dieback-A conservation biology challenge. Biological Conservation, 158, 37-49.

Pavlic, D., Slippers, B., Coutinho, T. A., Wingfield, M. J. (2007). Botryosphaeriaceae occurring on native Syzygium cordatum in South Africa and their potential threat to Eucalyptus. Plant Pathology, 56, 624-636.

Pavlic, D., Wingfield, M.J., Barber, P., Slippers, B., Hardy, G.E.StJ., Burgess, T.I. (2008). Seven new species of the Botryosphaeriaceae from baobab and other native trees in Western Australia. Mycologia, 100, 851-866.

Pérez, C. A., Wingfield, M. J., Slippers, B., Altier, N. A., Blanchette, R. A. (2010). Endophytic and cankerassociated Botryosphaeriaceae occurring on non-native Eucalyptus and native Myrtaceae trees in Uruguay. Fungal Diversity, 41, 53-69.

Phillips, A.J.L., Alves, A., Abdollahzadeh, J., Slippers, B., Wingfield, M.J., Groenewald, J.Z., Crous, P.W. (2013). The Botryosphaeriaceae: genera and species known from culture. Studies in Mycology, 76, 51-167.

Pillay, K., Slippers, B., Wingfield, M.J., Gryzenhout, M. (2013). Diversity and distribution of co-infecting Botryosphaeriaceae from Eucalyptus grandis and Syzygium cordatum in South Africa. South African Journal of Botany, 84, 38-43.

Piškur, B., Pavlic, D., Slippers, B., Ogris, N., Maresi, G., Wingfield, M.J., Jurc. D. (2011). Diversity and pathogenicity of Botryosphaeriaceae on declining Ostrya carpinifolia in Slovenia and Italy following extreme weather conditions. European Journal of Forest Research, 130, 235-249.

Posada, D. (2008). jModelTest: phylogenetic model averaging. Molecular Biology and Evolution, 25, 1253-1256.

Quaglia, M., Moretti, C., Buonaurio, R. (2014). Molecular characterization of Diplodia seriata, a new pathogen of Prunus laurocerasus in Italy. Phytoparasitica, 42, 189-197. 
R Core Team (2015). R: A language and environment for statistical computing. R Foundation for Statistical Computing,Vienna, Austria. URL http://www.R-project.org/.

Rodas, C. A., Slippers, B., Gryzenhout, M., Wingfield, M. J. (2009). Botryosphaeriaceae associated with Eucalyptus canker diseases in Colombia. Forest Pathology, 39, 110-123.

Sakaladis, M. (2004). Resolving the Botryosphaeria ribis - B. parva species complex; a molecular and phenotypic investigation, Honors thesis. School of Biological Sciences and Biotechnology, Murdoch University, Western Australia.

Sakalidis, M. L., Slippers, B., Wingfield, B. D., Hardy, G. S. J., Burgess, T. I. (2013). The challenge of understanding the origin, pathways and extent of fungal invasions: global populations of the Neofusicoccum parvum-N. ribis species complex. Diversity and Distributions, 19, 873-883.

Sakalidis, M.L., Hardy, G.E.S.J., Burgess, T.I. (2011). Endophytes as potential pathogens of the baobab species Adansonia gregorii: a focus on the Botryosphaeriaceae. Fungal Ecology, 4, 1-14.

Shannon, C.E., Weaver, W. (1949). The mathematical theory of communication. University of Illinois Press, Urbana, $144 \mathrm{p}$.

Shochat, E., Warren, P. S., Faeth, S. H., McIntyre, N. E., Hope, D. (2006). From patterns to emerging processes in mechanistic urban ecology. Trends in Ecology and Evolution, 21, 186-191.

Slippers, B., Boissin, E., Phillips, A.J.L., Groenewald, J.Z., Lombard, L., Wingfield, M.J., Postma, A., Burgess, T., Crous, P.W. (2013). Phylogenetic lineages in the Botryosphaeriales: a systematic and evolutionary framework. Studies in Mycology, 76, 31-49.

Slippers, B., Burgess, T., Pavlic, D., Ahumada, R., Maleme, H., Mohali, S., Wingfield, M.J. (2009). A diverse assemblage of Botryosphaeriaceae infect Eucalyptus in native and non-native environments. Southern Forests, 71, 101-110.

Slippers, B., Wingfield, M.J. (2007). The Botryosphaeriaceae as endophytes and latent pathogens of woody plants: diversity, ecology and impact. Fungal Biology Reviews, 21, 90-106.

Slippers, B., Crous, P. W., Jami, F., Groenewald, J. Z., Wingfield, M. J. (2017). Diversity in the Botryosphaeriales: Looking back, looking forward. Fungal Biology, 121, 307-321.

Stojanović, A., Marković, C. (2004). Parasitoid complex of Cameraria ohridella (Lepidoptera: Gracillariidae) in Serbia. Phytoparasitica, 32, 132-140. 
Stojanović, D. B., Levanič, T., Matović, B., Orlović, S. (2015). Growth decrease and mortality of oak floodplain forests as a response to change of water regime and climate. European Journal of Forest Research, 134, $555-567$.

Stanivuković, Z., Karadžić, D., Milenković, I (2014). The first record of the parasitic fungus Hymenoscyphus fraxineus (T. Kowalski) Baral, Queloz, Hosoya on the common ash in Bosnia and Herzegovina (in Serbian with English summary). Šumarstvo, 3-4, 19-32.

Swofford, D.L. (2003). PAUP*: phylogenetic analyses using parsimony (*and other methods). Version 4. Sunderland, Massauchusetts: Sinauer Associates.

Taylor, K., Barber, P.A., Hardy, G.E.S.J., Burgess, T.I. (2009). Botryosphaeriaceae from tuart (Eucalyptus gomphocephala) woodland, including descriptions of four new species. Mycological Research, 113, 337353.

Valade, R., Kenis, M., Hernandez-Lopez, A., Augustin, S., Mari Mena, N., Magnoux, E., Rougerie, R., Lakatos, F., Roques, A., Lopez-Vaamonde, C. (2009). Mitochondrial and microsatellite DNA markers reveal a Balkan origin for the highly invasive horse-chestnut leaf miner Cameraria ohridella (Lepidoptera, Gracillariidae). Molecular Ecology, 18, 3458-3470.

Varela, P.C., Redondo Fernández, V., Mansilla Vázquez, J.P., Aguín Casal, O. (2011). First report of dieback on hybrid Rhododendrons caused by Neofusicoccum luteum and N. parvum in Spain. Plant Disease, 95, 221.

Varga, I., Taller, J., Baltazár, T., Hyvönen, J., Poczai, P. (2012). Leaf-spot disease on European mistletoe (Viscum album) caused by Phaeobotryosphaeria visci: a potential candidate for biological control. Biotechnology Letters, 34, 1059-1065.

Vasić, M., Duduk, N., Vico, I., Ivanović, M.S. (2013). First Report of Botryosphaeria dothidea causing white rot of apple fruit in Serbia. Plant Disease, 97, 1659.

White, T. J., Bruns, T., Lee, S., Taylor, J., Innis, M. A., Gelfand, D. H., Sninsky, J. J, White, T. J. (1990). Amplification and direct sequencing of fungal ribosomal RNA genes for phylogenetics. In M.A. Innis, D.H. Gelfand, J.J. Sninsky, T.J. White (Eds.), PCR protocols: a guide to methods and applications, New York, Academic Press, pp. 315-322.

Wingfield, M. J., Brockerhoff, E. G., Wingfield, B. D., Slippers, B. (2015). Planted forest health: the need for a global strategy.Science, 349, pp. 832-836. 
Xenopoulos, S., Andréoli, C., Panconesi, A., Pinto Ganhao, J., Tusset, J. J. (1990). In J. Ponchet (Ed.) Importance of cypress. In Progress in EEC Research on Cypress Diseases. Report EUR 12493. Brussels, Luxembourg: Commission of the European Communities, pp. 1-13.

Zlatković, M., Keča, N., Wingfield, M.J., Jami, F., Slippers, B. (2016a). Botryosphaeriaceae associated with the dieback of ornamental trees in the Western Balkans. Antonie van Leeuwenhoek Journal of Microbiology, 109, 546-564

Zlatković, M., Keča, N., Wingfield, M.J., Jami, F., Slippers, B. (2016b). Shot hole disease on Prunus laurocerasus caused by Neofusicoccum parvum in Serbia. Forest Pathology, 46, 666-669.

Zlatković, M., Keča, N., Wingfield, M.J., Jami, F., Slippers, B. (2017). New and unexpected host associations of Diplodia sapinea in the Western Balkans. Forest Pathology, 47, 1-11. 


\section{Supplementary material}

Figure S1. A diagram outlining the materials and methods used in this study.

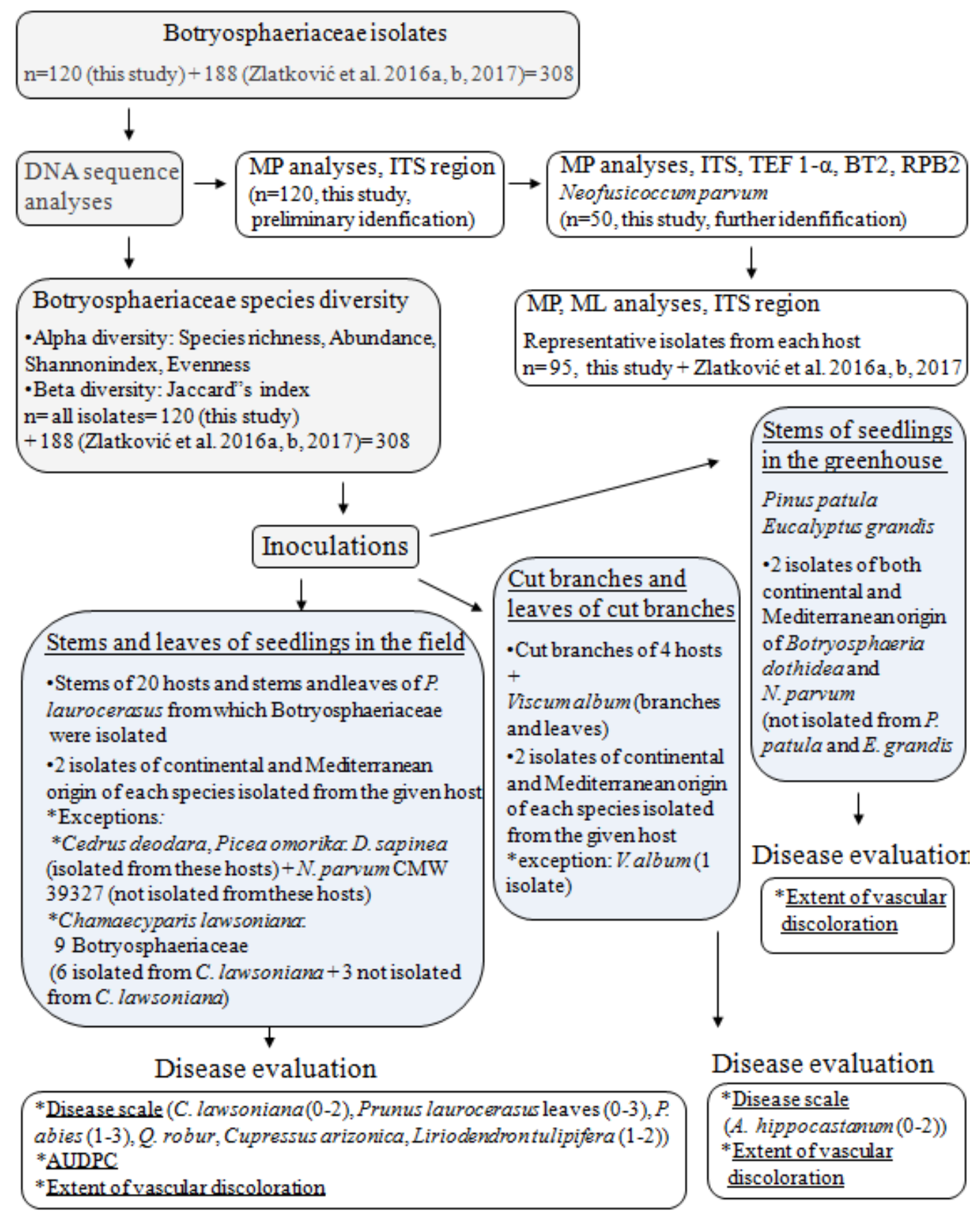


Figure S2. Botryosphaeriaceae species associated with: a- gymnosperms, b- angiosperms. Data refer to the whole set of Botryosphaeriaceae isolates from the Western Balkans, including isolates from this and from previous studies (Zlatković et al. 2016a, b, 2017).

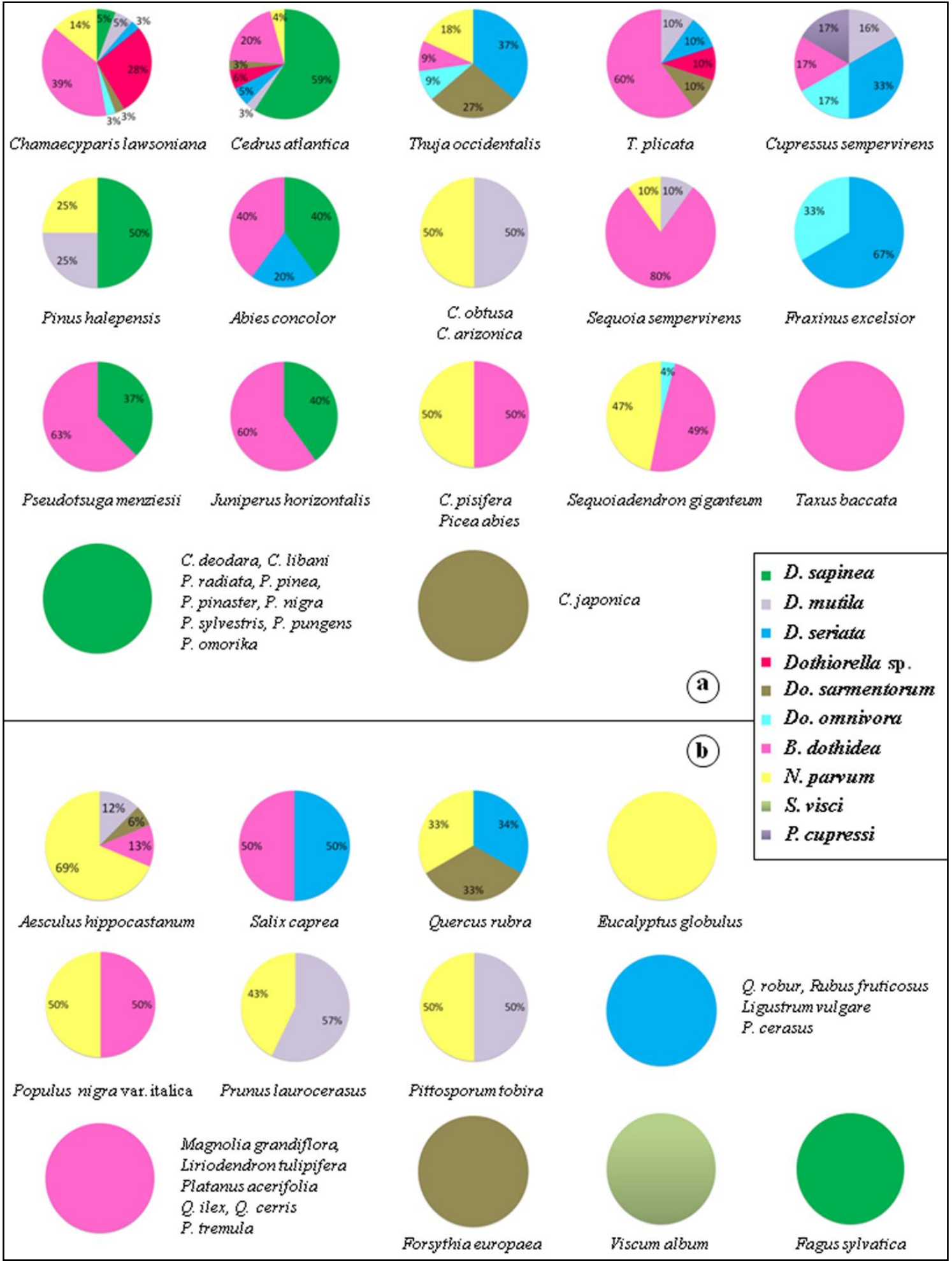


Figure S3. Botryosphaeriaceae species isolated from hosts from the Mediterranean and Continental climate-type regions. Data refer to the whole set of Botryosphaeriaceae isolates from the Western Balkans, including isolates from this and from previous studies (Zlatković et al. 2016a, b, 2017).

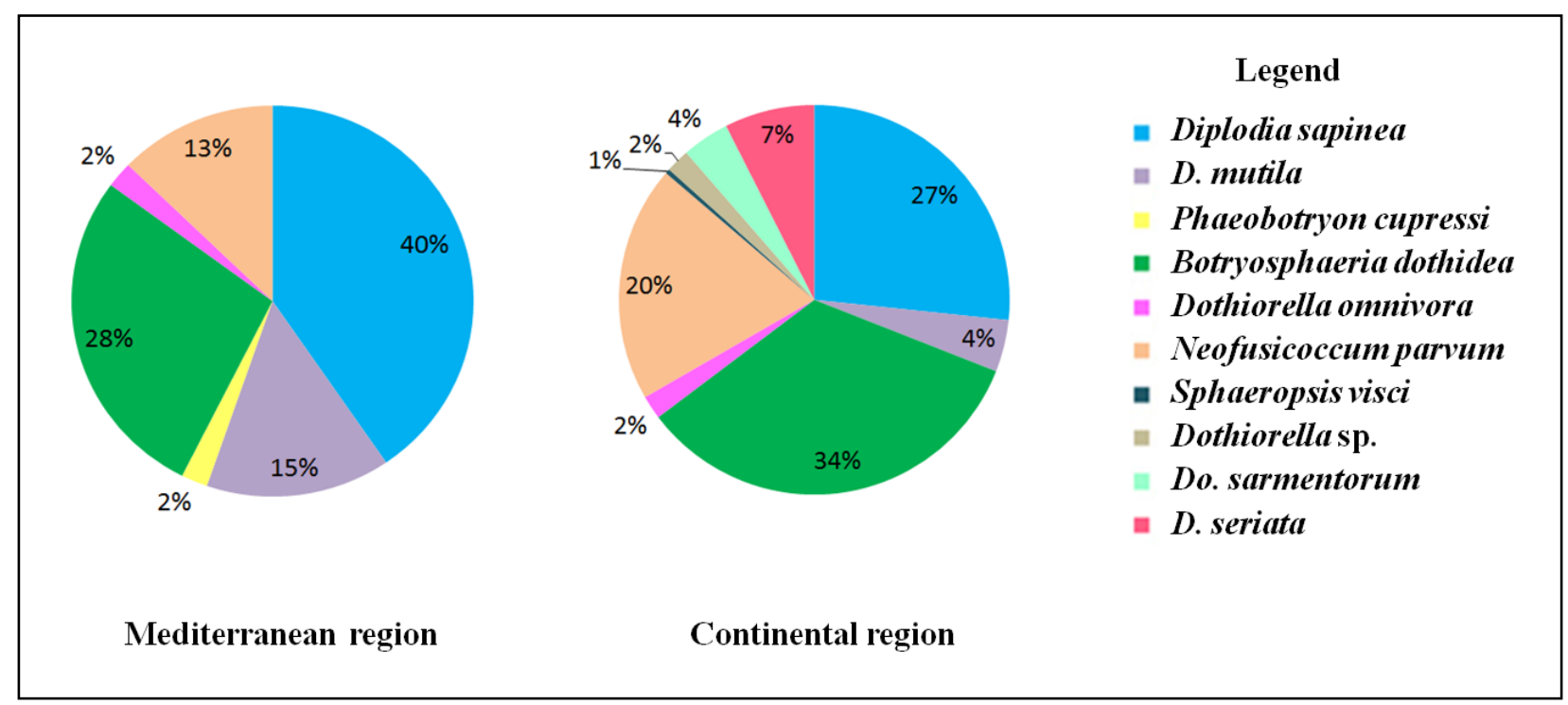


Figure S4. Signs and symptoms associated with Phaeobotryon cupressi and Botryosphaeria dothidea on inoculated Chamaecyparis lawsoniana seedlings. a. Browning of the leaves from the inoculation point upwards and downwards; b. Elongated, girdling, sunken cankers with cracks along the canker margin and inside the canker formed after inoculation with P. cupressi; c. Elliptical canker formed after inoculation with B. dothidea CMW 39315 (c); d, e. Pycnidia of $P$. cupressi formed in the dead stem tissue; $\mathrm{f}$, g. Control seedling inoculated with sterile WA plug showing no disease symptoms. Bars: $\mathrm{d}=1 \mathrm{~cm}, \mathrm{e}=0.5 \mathrm{~cm}$.

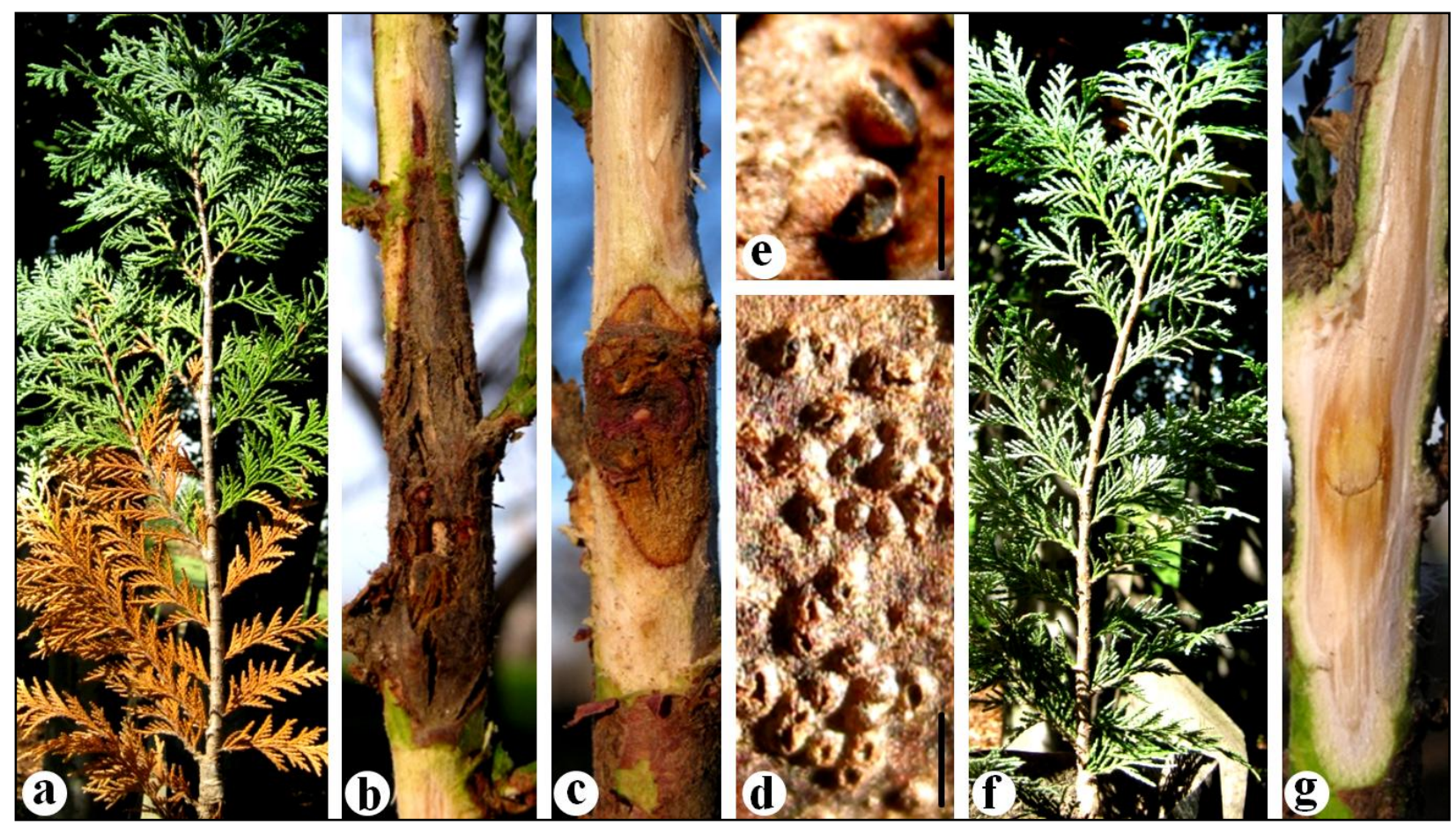


Figure S5. Elongated, girdling cankers with $D$. seriata pycnidia produced on canker surfaces of Quercus robur seedlings after inoculation with D. seriata: CMW 39382 (a, b), CMW 39376 (c-e). Bars: a, c-e= 1 $\mathrm{cm}, \mathrm{b}=0.5 \mathrm{~cm}$.

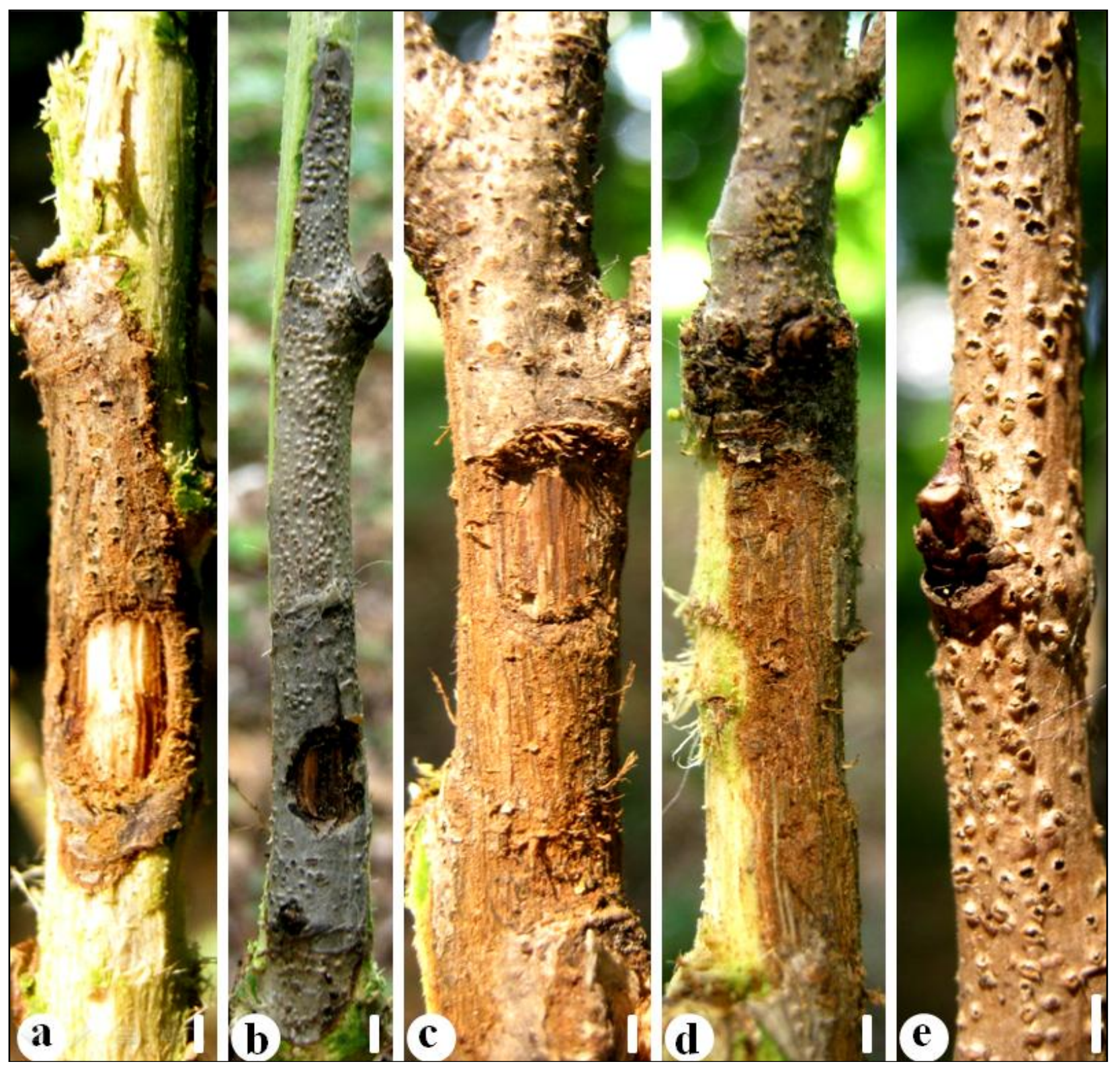


Figure S6. Signs and symptoms associated with Diplodia sapinea, Neofusicoccum parvum and Botryosphaeria dothidea on inoculated Picea abies seedlings. a-c. Elongated, girdling, resin-soaked necrotic lesions formed after inoculation with: B. dothidea CMW 39301 (a), CMW 39315 (b), N. parvum CMW 39317 (c). d. Wilting of shoots and needle cast of seedlings inoculated with N. parvum CMW 39317. e. Control plant inoculated with sterile WA plug showing no disease symptoms.

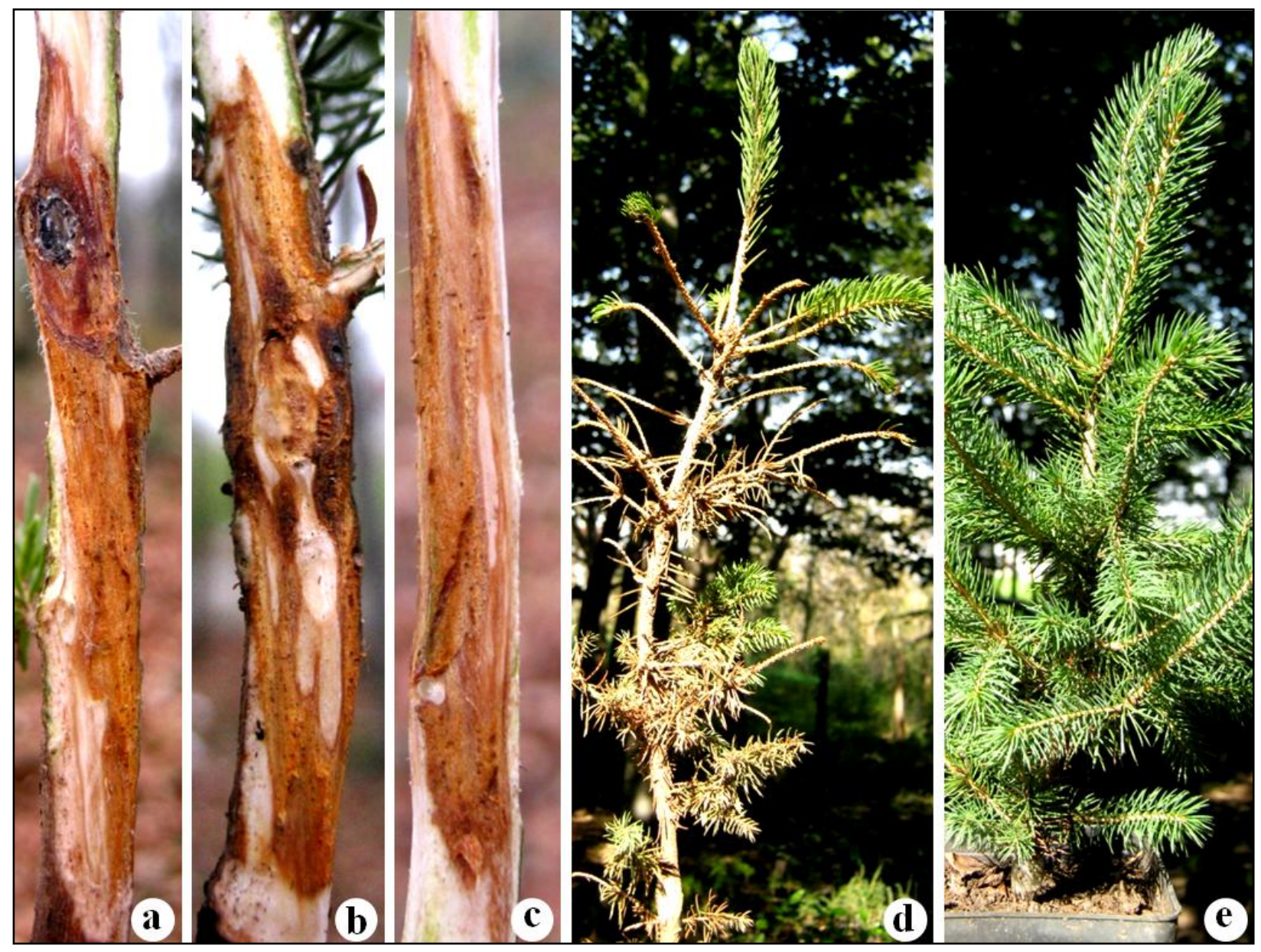


Figure S7. Signs and symptoms associated with Botryosphaeria dothidea and Diplodia mutila on inoculated Cupressus arizonica seedlings. a, b. Elliptical necrotic lesions formed after inoculation with $D$. mutila CMW 39348. c-f. Elongated, girdling, sunken cankers with vertical cracks within the canker and along the canker margins formed after inoculation with B. dothidea CMW 39315. g. Pycnidia of $B$. dothidea formed in the cankered tissue after inoculation with B. dothidea CMW 39315.

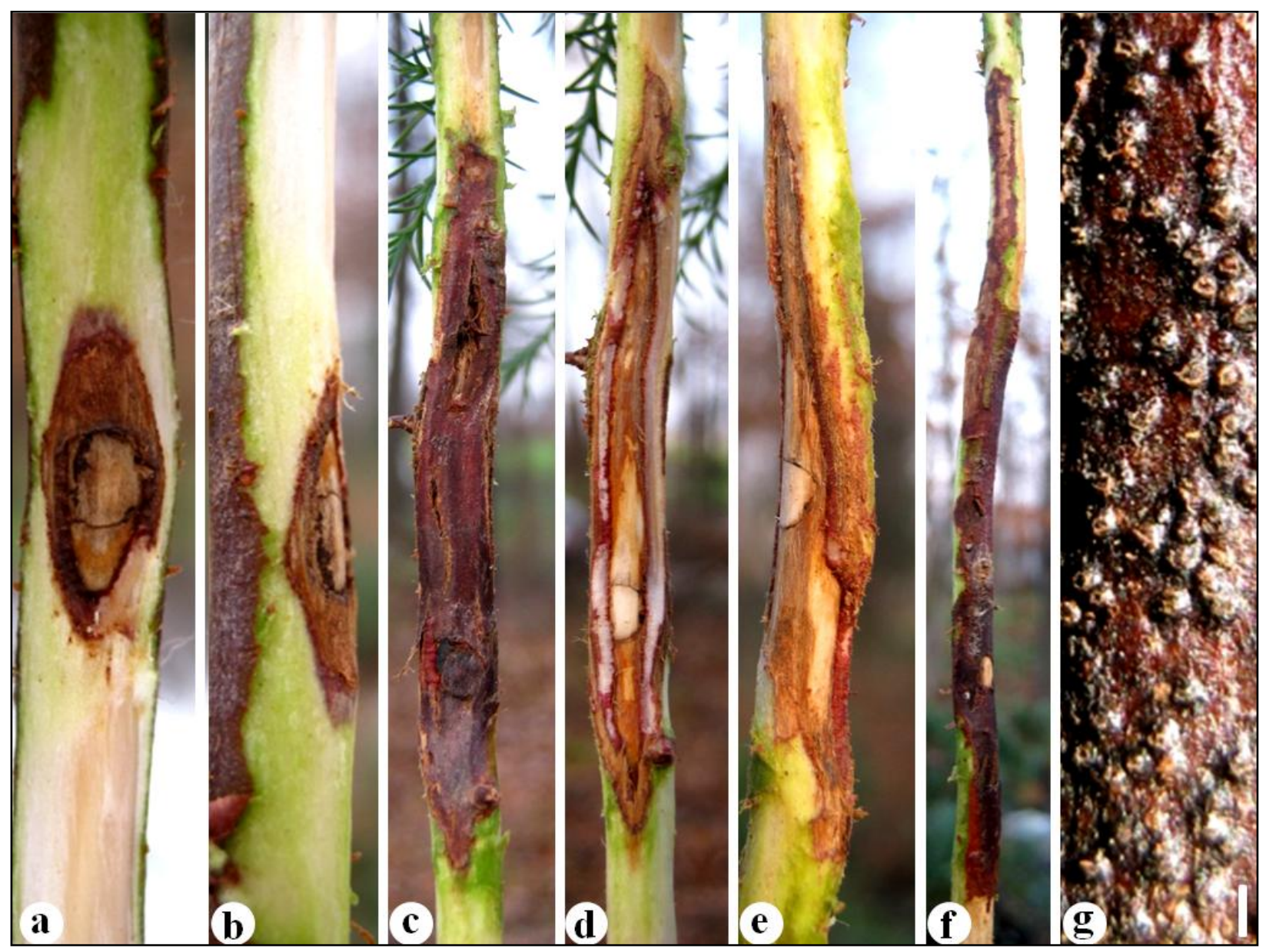


Figure S8. Signs and symptoms associated with Neofusicoccum parvum on inoculated Populus nigra var. italica seedlings. a. Necrotic lesion formed after inoculation with N. parvum CMW 39317. b-e. Girdling, sunken cankers with cracks within the canker and $N$. parvum pycnidia produced after inoculation with $N$. parvum CMW 39327. f. Control seedling inoculated with sterile WA plug showing no disease symptoms. Bars: $\mathrm{c}-\mathrm{e}=1 \mathrm{~cm}$.

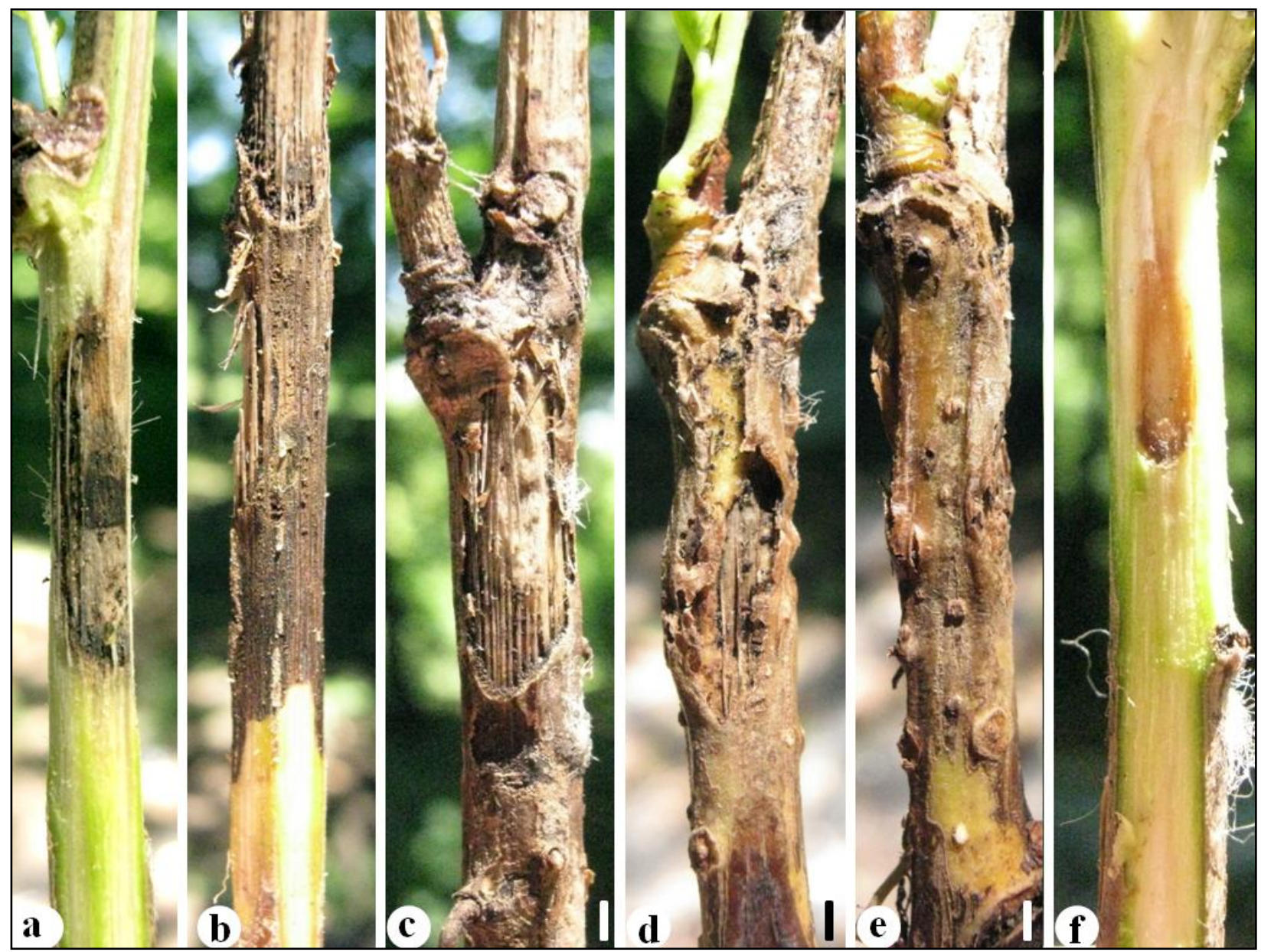


Figure S9. Signs and symptoms associated with Botryosphaeria dothidea, Neofusicoccum parvum and Dothiorella omnivora on inoculated Sequoiadendron giganteum seedlings. a. Shoot die-back from the inoculation point upwards; b. Girdling stem lesions; c. Control seedling inoculated with sterile WA plug showing no disease symptoms.

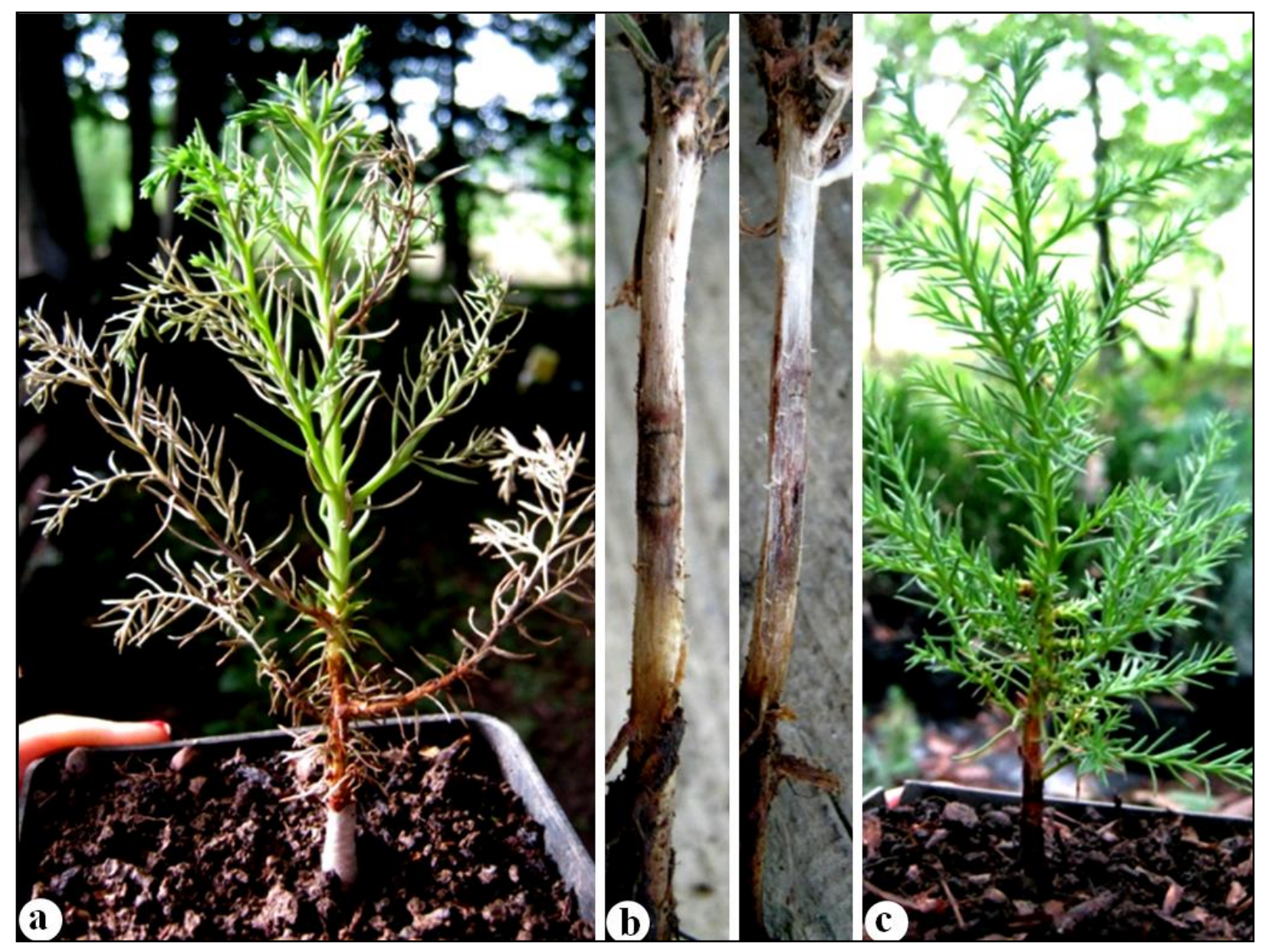


Figure S10. Signs and symptoms associated with Diplodia seriata and Botryosphaeria dothidea on inoculated Abies concolor seedlings. a. Stem die-back; b. Pycnidia of D. seriata formed on the dead bark after inoculation with D. seriata CMW 39376; c. Control seedling inoculated with sterile WA plug showing no disease symptoms. Bar: $b=0.5 \mathrm{~cm}$.

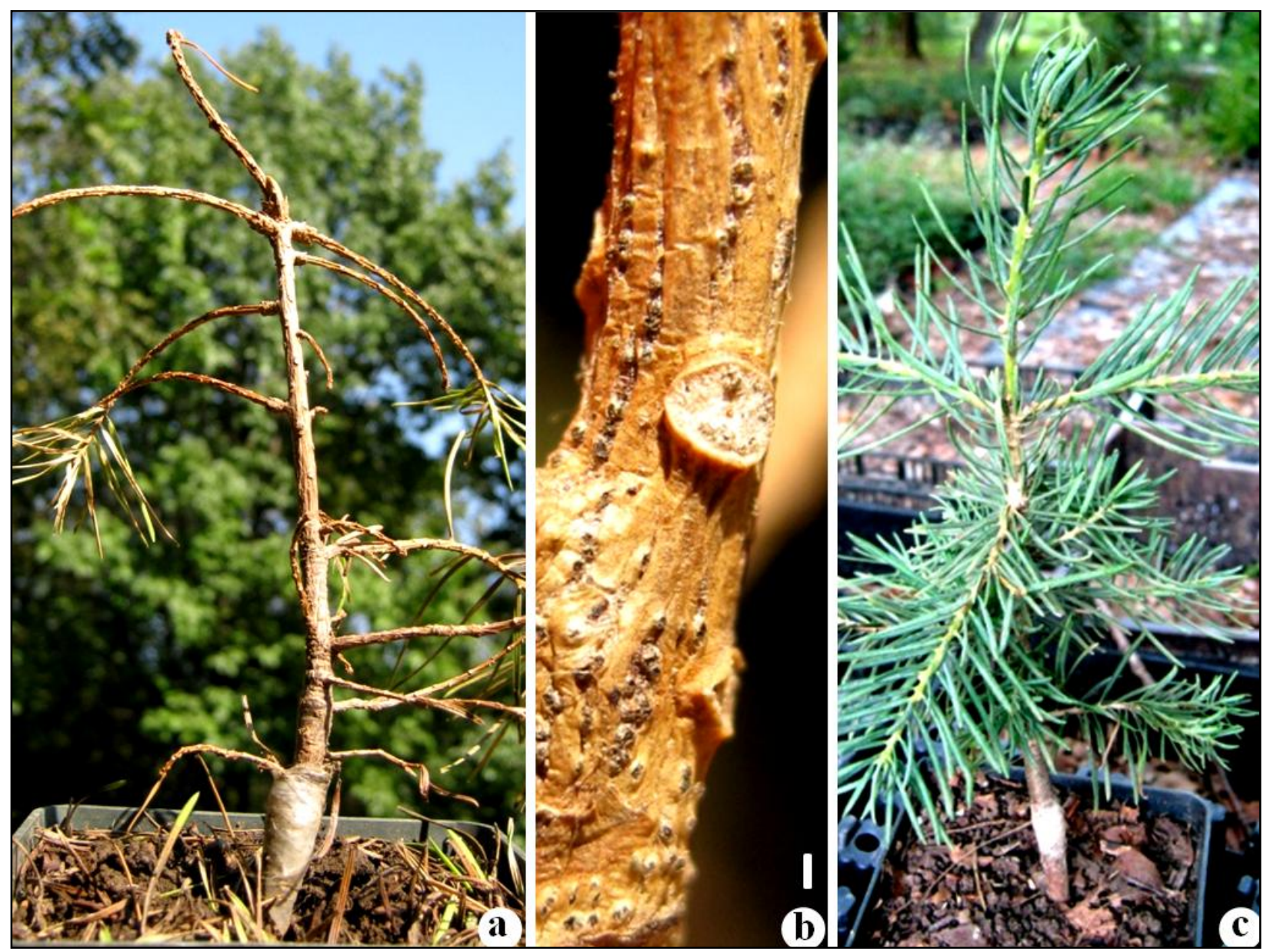


Figure S11. Signs and symptoms associated with Diplodia seriata, Neofusicoccum parvum and Botryosphaeria dothidea on inoculated Thuja occidentalis seedlings. a. Yellowing, browning and reddening of the leaves; b. Black and necrotic leaves; c. Dry leaves; d. Control seedling inoculated with sterile WA plug showing no no disease symptoms.

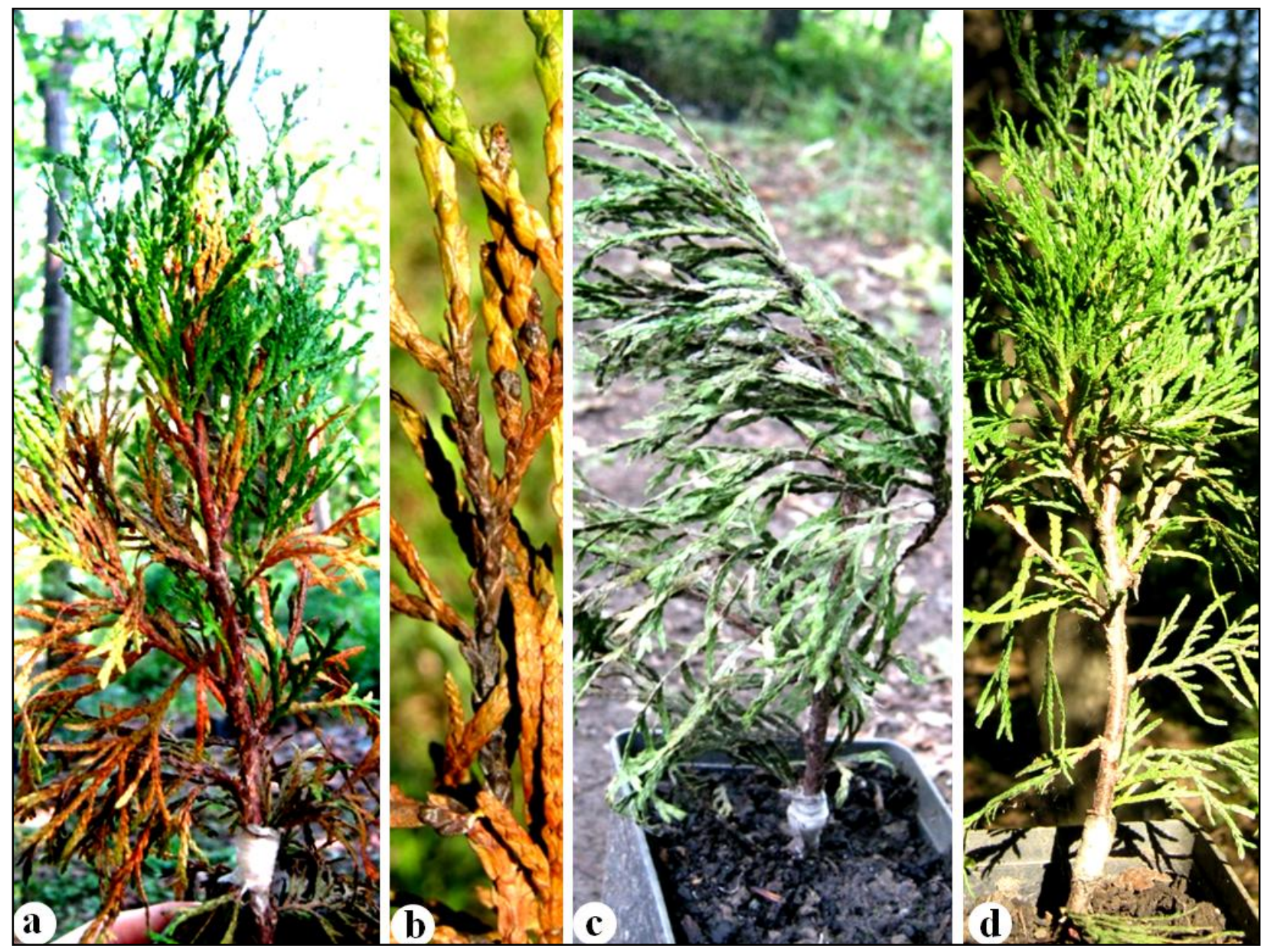


Figure S12. Signs and symptoms associated with Diplodia mutila, D. seriata and Botryosphaeria dothidea on inoculated Cupressus sempervirens seedlings. a. Yellowing of the needles and shoot die-back from the inoculation point upwards; b. Pycnidia of $D$. seriata produced in the dead stem tissue; c. Control seedling inoculated with sterile WA plug showing no disease symptoms. Bar: $b=0.5 \mathrm{~cm}$.

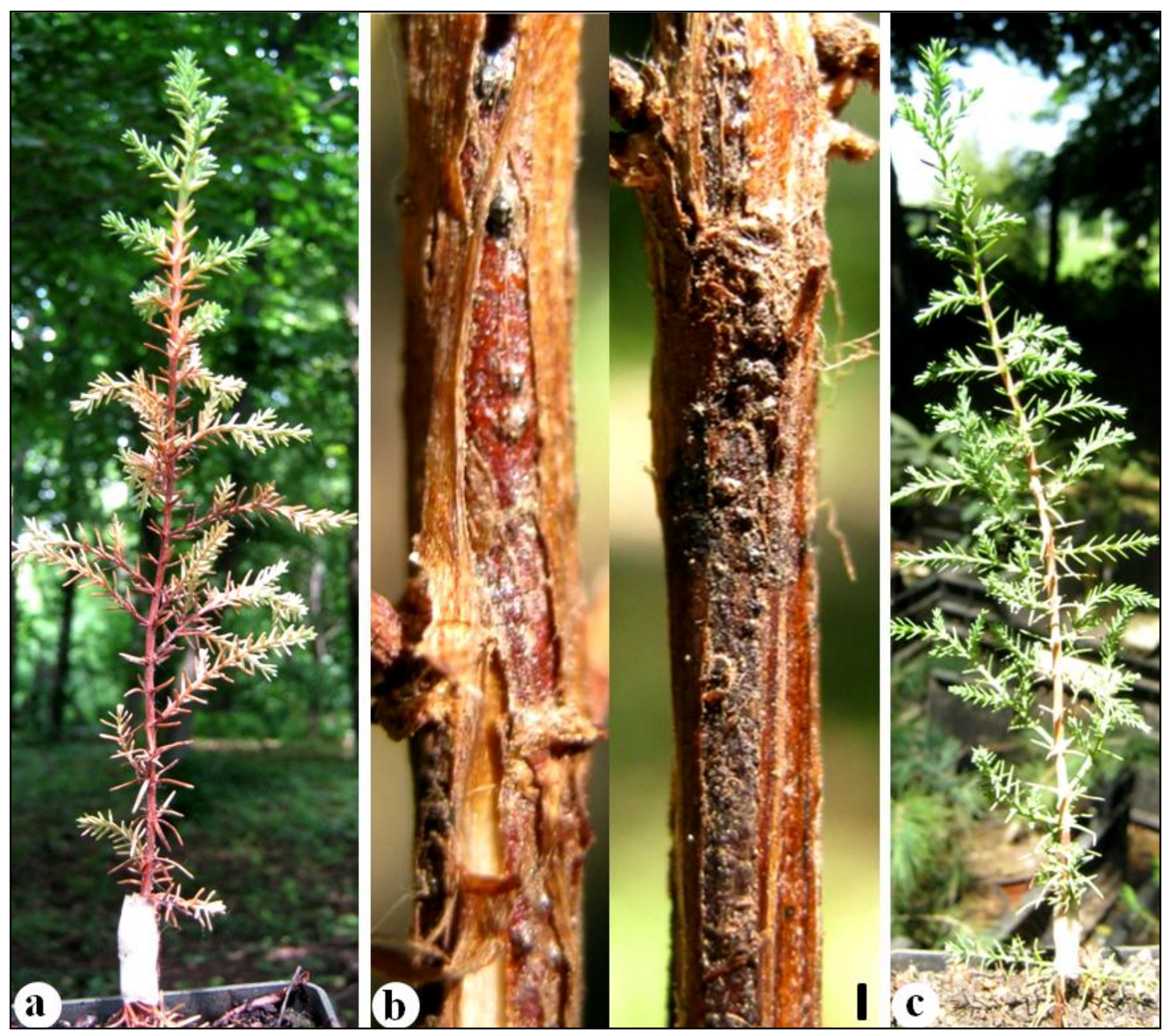


Figure S13. Signs and symptoms associated with Diplodia sapinea and Neofusicoccum parvum on inoculated Picea omorika seedlings. a.Wilting of shoots and needle cast; b. Girdling stem lesions; c. Pycnidia produced in the dead stem tissue. d. Control seedling inoculated with sterile WA plug showing no disease symptoms. Bar: c=0.5cm. Data for D. sapinea were retreived from Zlatković et al. 2017.

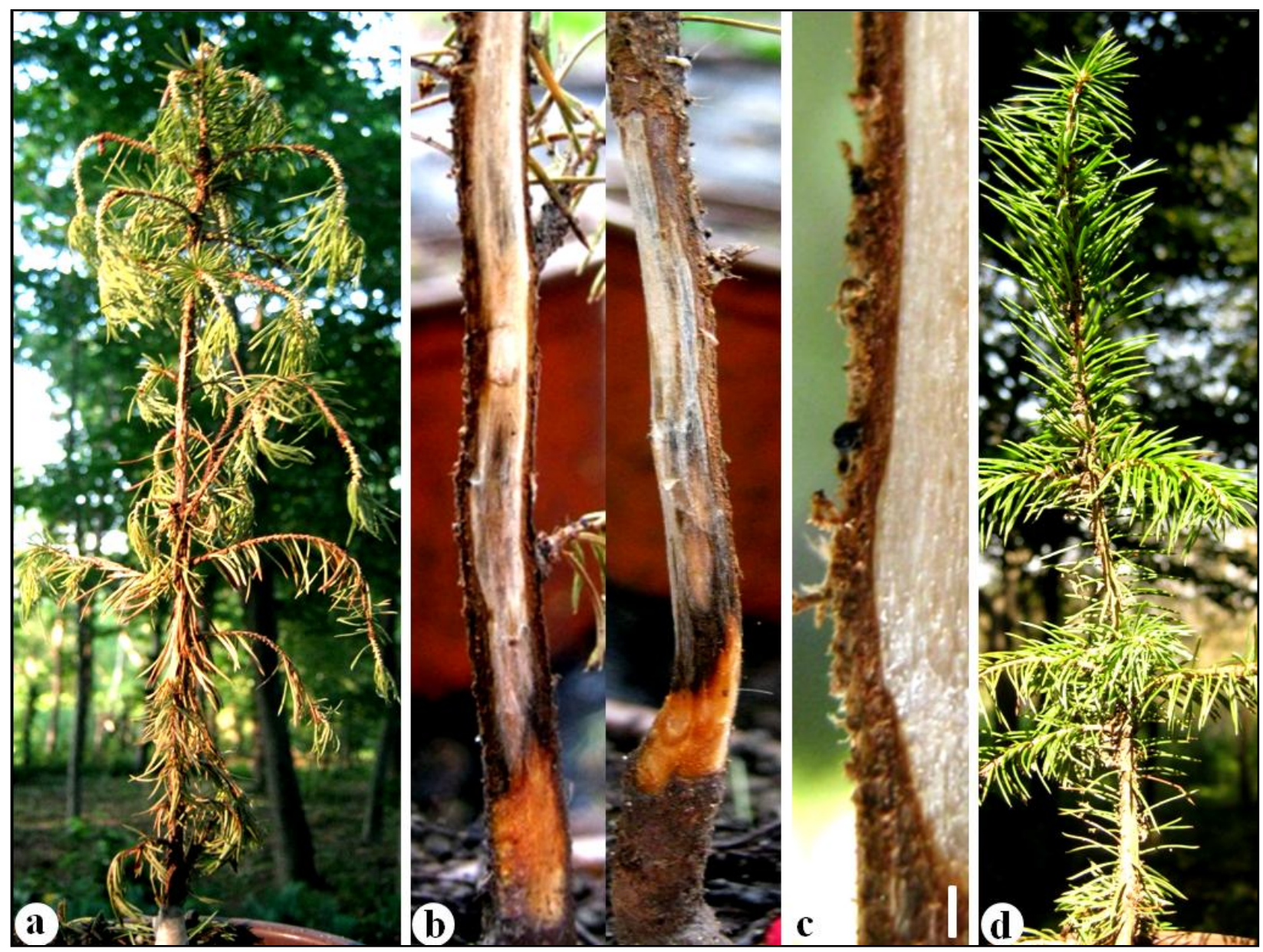


Figure S14. Signs and symptoms associated with Diplodia seriata and Botryosphaeria dothidea on inoculated Ligustrum vulgare and Magnolia grandifolia seedlings. a.Vascular discoloration of L. vulgare seedling inoculated with D. seriata CMW 39382; b. Control L. vulgare seedling inoculated with sterile WA plug showing no disease symptoms;c. Vascular discoloration of $M$. grandifolia seedling inoculated with $B$. dothidea CMW 39315; d. Pycnidia of B. dothidea produced on M. grandifolia seedling inoculated with $B$. dothidea CMW 39301. Control M. grandifolia seedling inoculated with sterile WA plug. Bar: $\mathrm{d}=0.5 \mathrm{~cm}$.

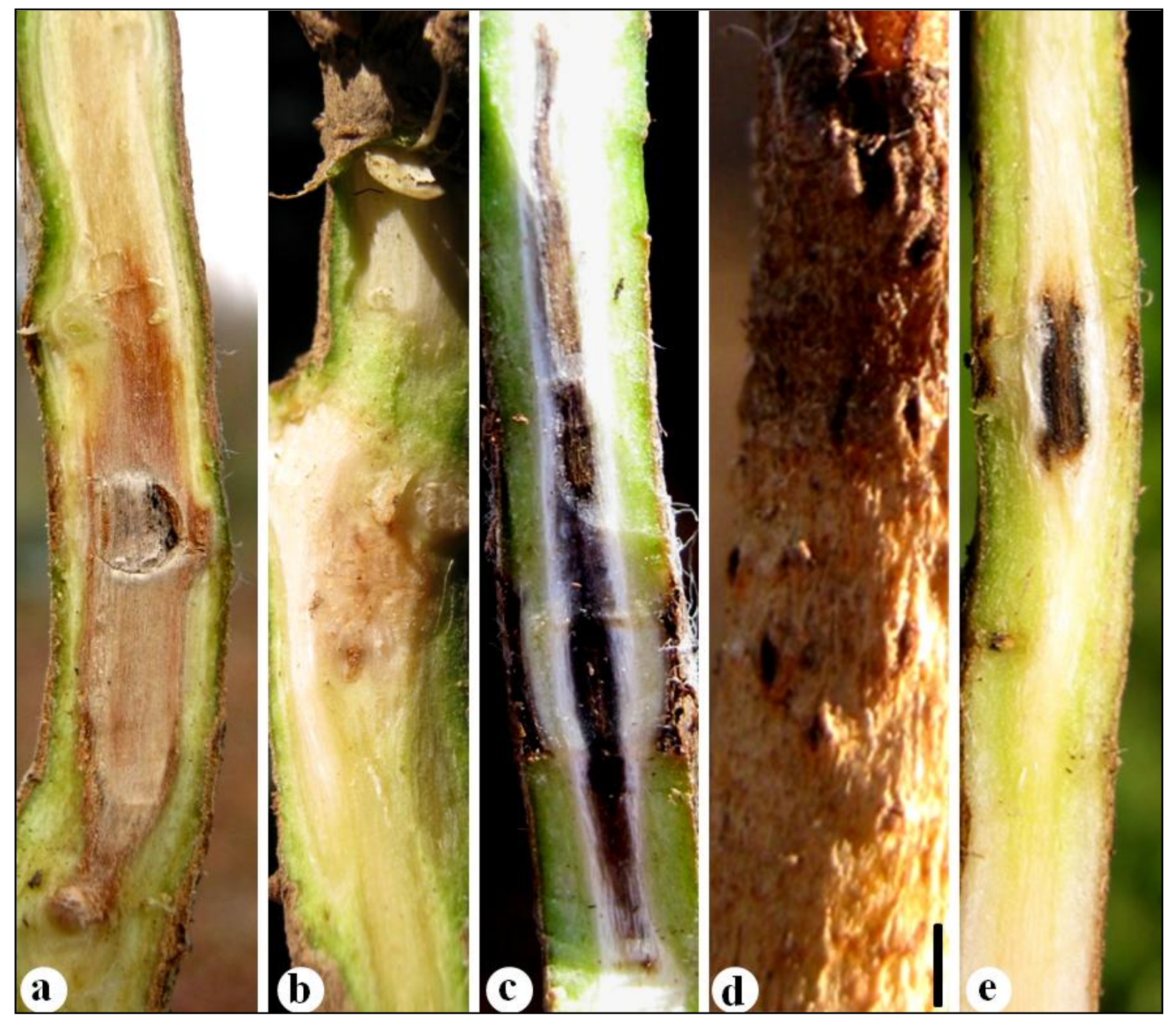


Figure S15. Signs and symptoms associated with Botryosphaeria dothidea on inoculated Liriodendron tulipifera seedlings. a. Lesion associated with B. dothidea CMW 39315; b. Stem die-back of seedling inoculated with B. dothidea CMW 39301; c, d. Pycnidia of B. dothidea produced in the dead stem tissue of seedlings inoculated with $B$. dothidea CMW 39301. e. Control seedling inoculated with sterile WA plug. Bars: $\mathrm{c}, \mathrm{d}=0.5 \mathrm{~cm}$.

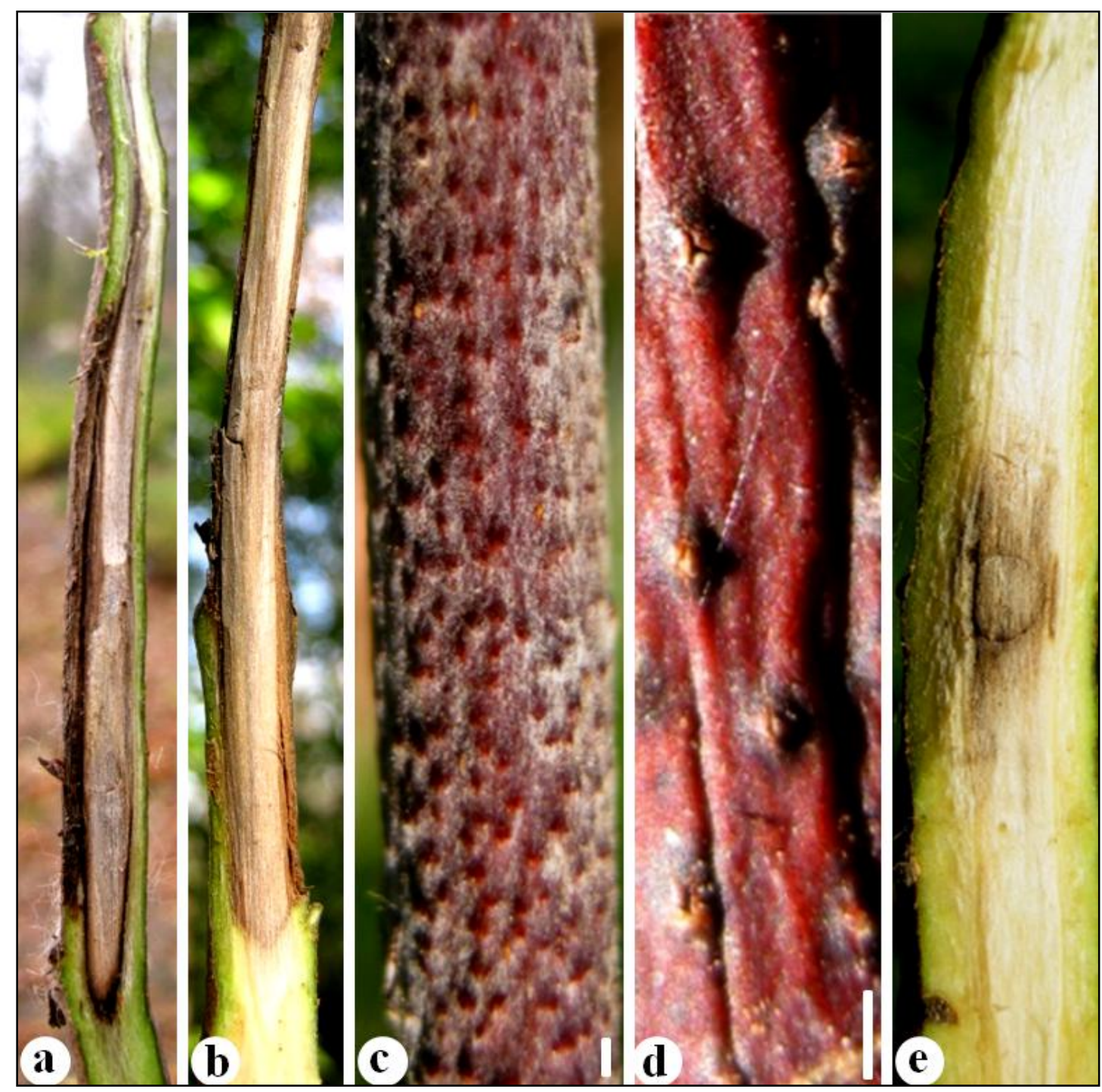


Figure S16. Signs and symptoms associated with Diplodia sapinea and Botryosphaeria dothidea on inoculated Pseudotsuga menziesii seedlings. a. Wilting of shoots, yellowing of the needles and needle desiccation of seedling inoculated with $D$. sapinea; b. Pycnidia of D. sapinea produced in the dead stem tissue of seedling inoculated with $D$. sapinea CMW 39329; c. Resinous lesion formed after inoculation with B. dothidea CMW 39301. d, e. Control seedling inoculated with sterile WA plug showing no disease symptoms. Bars: $b=0.5 \mathrm{~cm}$. Data for D. sapinea were retreived from Zlatković et al. 2017 and serve for comparison with inoculations conducted with $B$. dothidea.

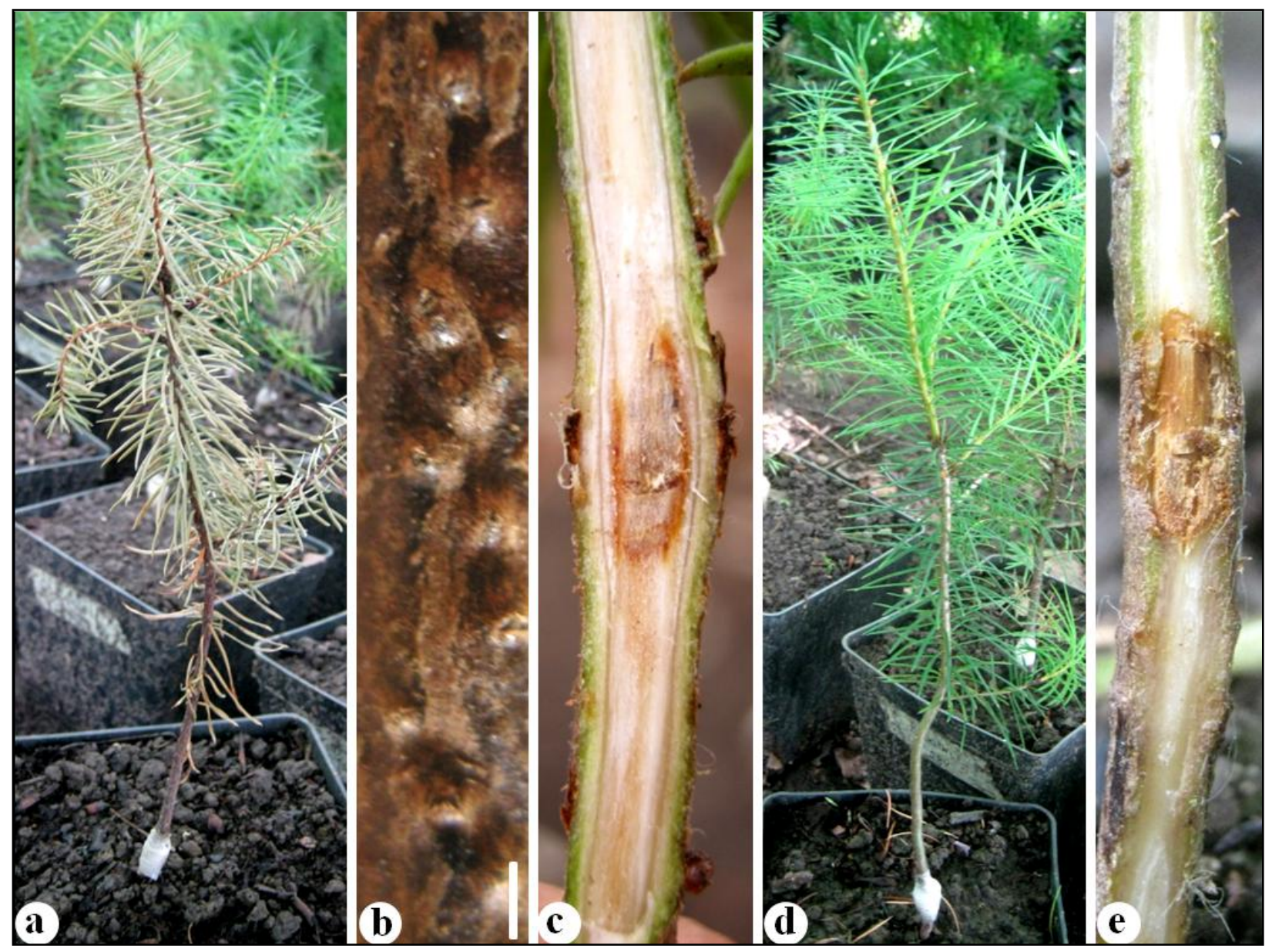


Figure S17. Signs and symptoms associated with Neofusicoccum parvum, Diplodia sapinea and Botryosphaeria dothidea on inoculated Cedrus atlantica and Juniperus horizontalis seedlings. a.Girdling lesions formed on $C$. atlantica after inoculation with N. parvum CMW 39327; b. Control C. atlantica seedling inoculated with sterile WA plug; c. Necrotic lesion formed on J. horizontalis after inoculation with B. dothidea CMW 39315. d. Necrotic lesion formed on J. horizontalis after inoculation with D. sapinea CMW 39329. e. Control J. horizontalis seedling inoculated with sterile WA plug. Data for D. sapinea were retreived from Zlatković et al. 2017.

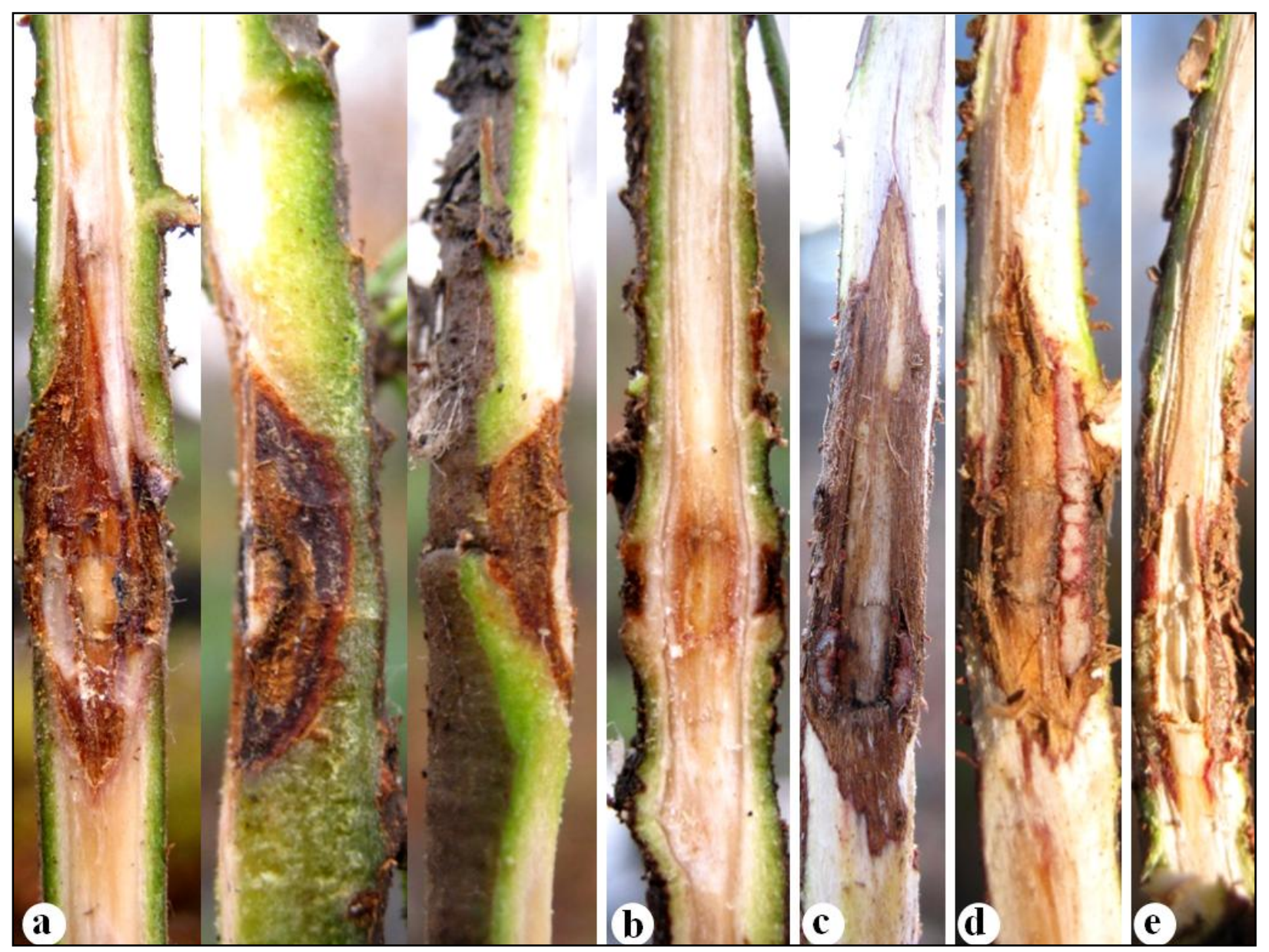


Figure S18. Signs and symptoms associated with Neofusicoccum parvum and Diplodia mutila on inoculated Pittosporum tobira and Prunus laurocerasus seedlings. a.Elongated necrotic lesion formed on P. tobira after inoculation with N. parvum CMW 39327; b. Control P. tobira seedling inoculated with sterile WA plug; c. Reddish-brown elliptical cankers with cracks inside the canker and along the canker margin formed on $P$. laurocerasus after inoculation with N. parvum CMW 39327; d. Dark brown lesions formed on $P$. laurocerasus after inoculation with $D$. mutila CMW 39348; e Dark brown lesions formed on a control $P$. laurocerasus seedling after inoculation with sterile WA.
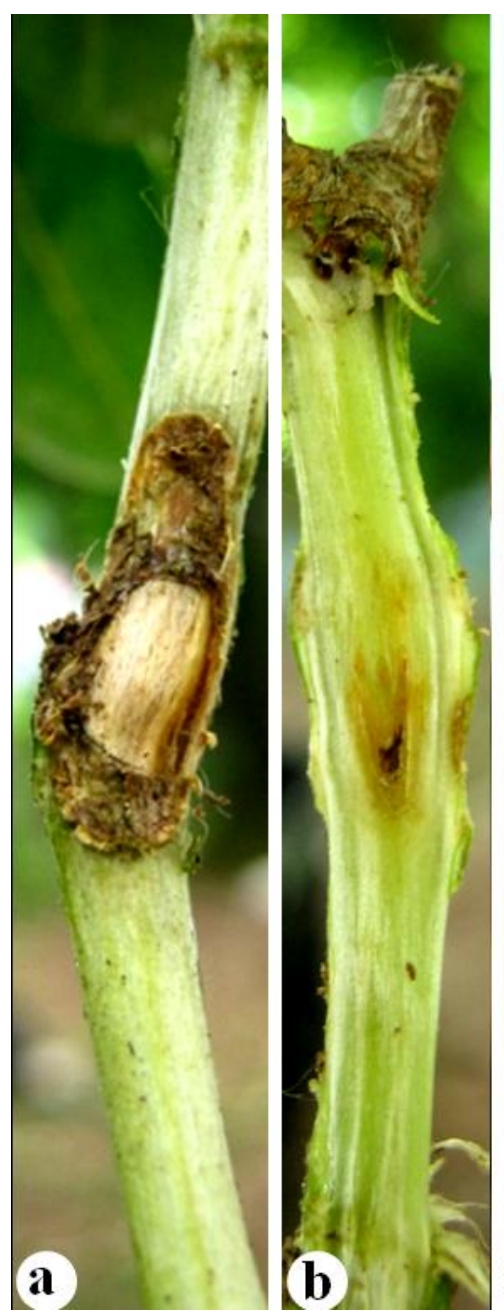
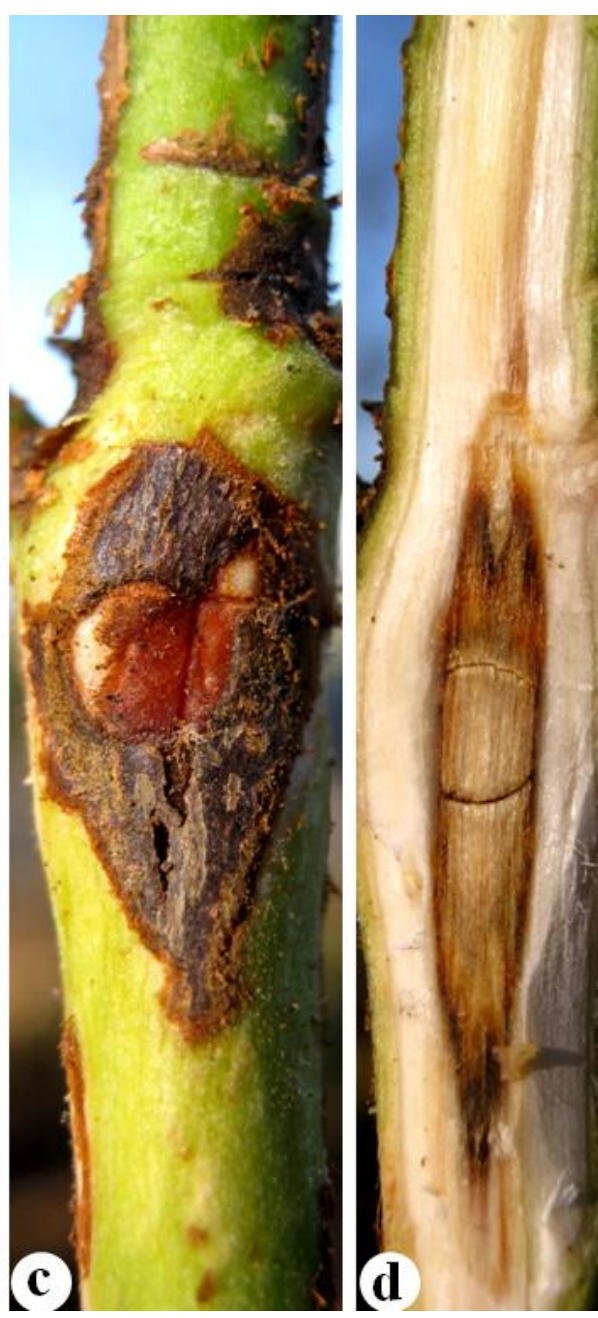

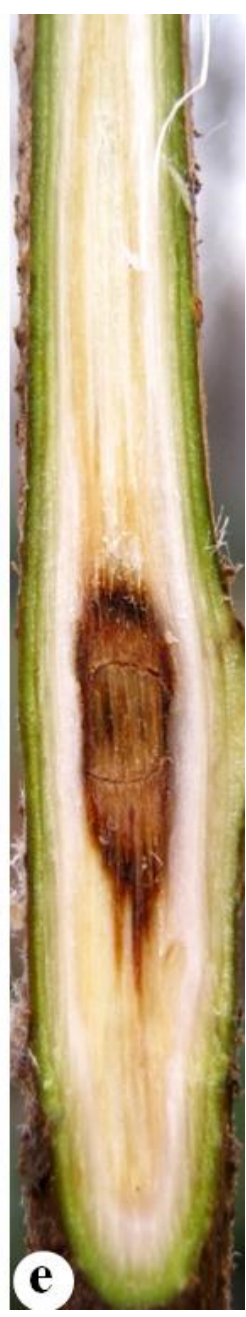


Figure S19. Signs and symptoms associated with Botryosphaeria dothidea, Neofusicoccum parvum, Diplodia mutila and Dothiorella sarmentorum on inoculated Aesculus hippocastanum branches. a, b. Pycnidia of Neofusicoccum parvum formed in the dead branch tissue after inoculation with N. parvum CMW 39327; c. Darkening of the vascular tissue associated with B. dothidea CMW 39301; Girdling lesion formed after inoculation with Do. sarmentorum CMW 39365.

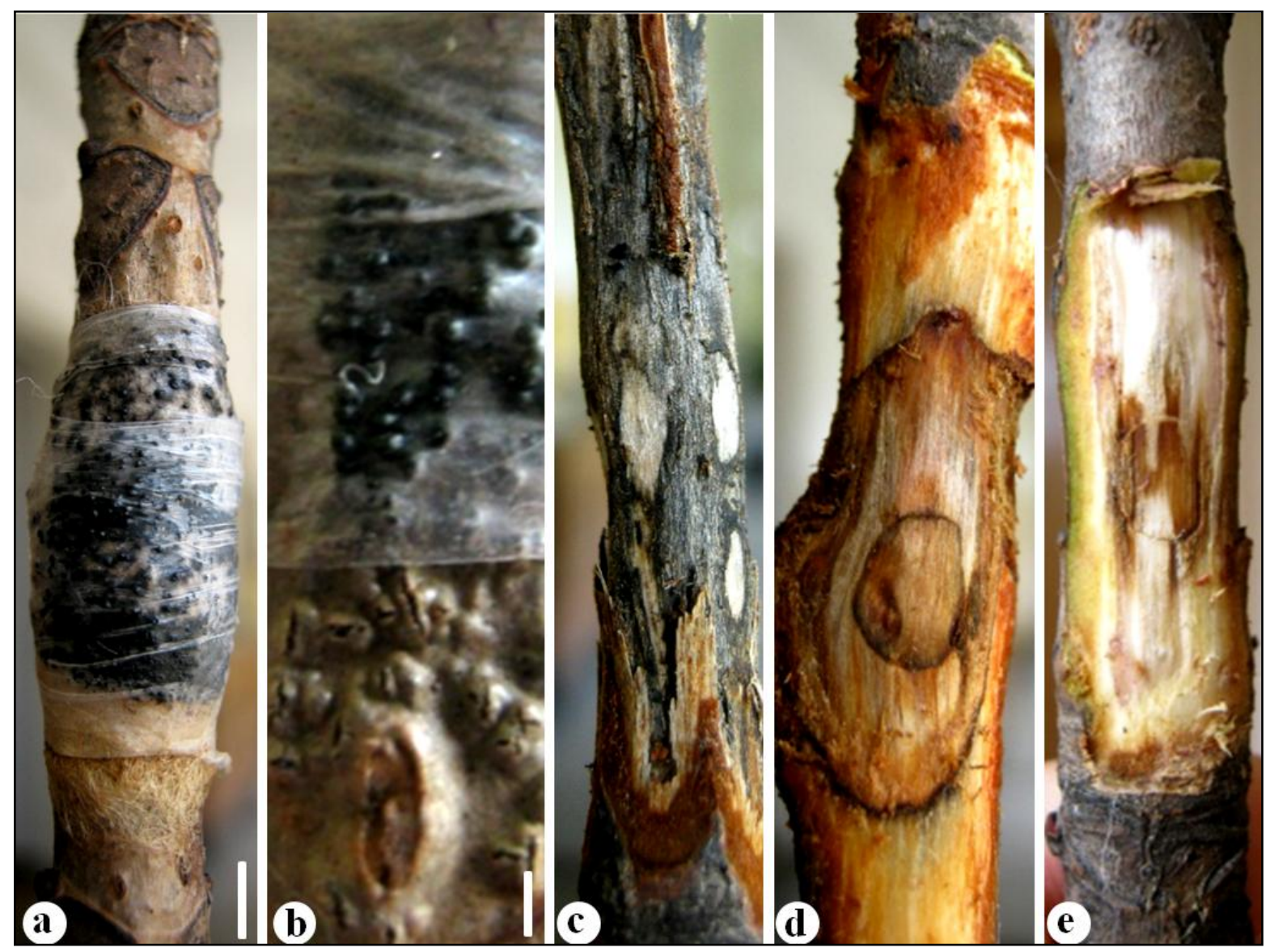


Figure S20. Signs and symptoms associated with Botryosphaeria dothidea and Diplodia seriata on inoculated Populus tremula, Quercus cerris and Fraxinus excelsior branches. a. Lesion associated with $B$. dothidea CMW 39315 on inoculated P. tremula branch; b. Girdling lesion associated with B. dothidea CMW 39301 on inoculated P. tremula branch; c. Control P. tremula branch inoculated with sterile WA plug; d. Lesion associated with B. dothidea CMW 39315 on inoculated Q. cerris branch; e. Control Q. cerris branch inoculated with sterile WA plug; f. Lesion associated with D. seriata CMW 39376 on inoculated F. excelsior branch; g. Pycnidia of $D$. seriata produced on $F$. excelsior branch after inoculation with $D$. seriata CMW 39376; h. Control F. excelsior branch inoculated with sterile WA plug.

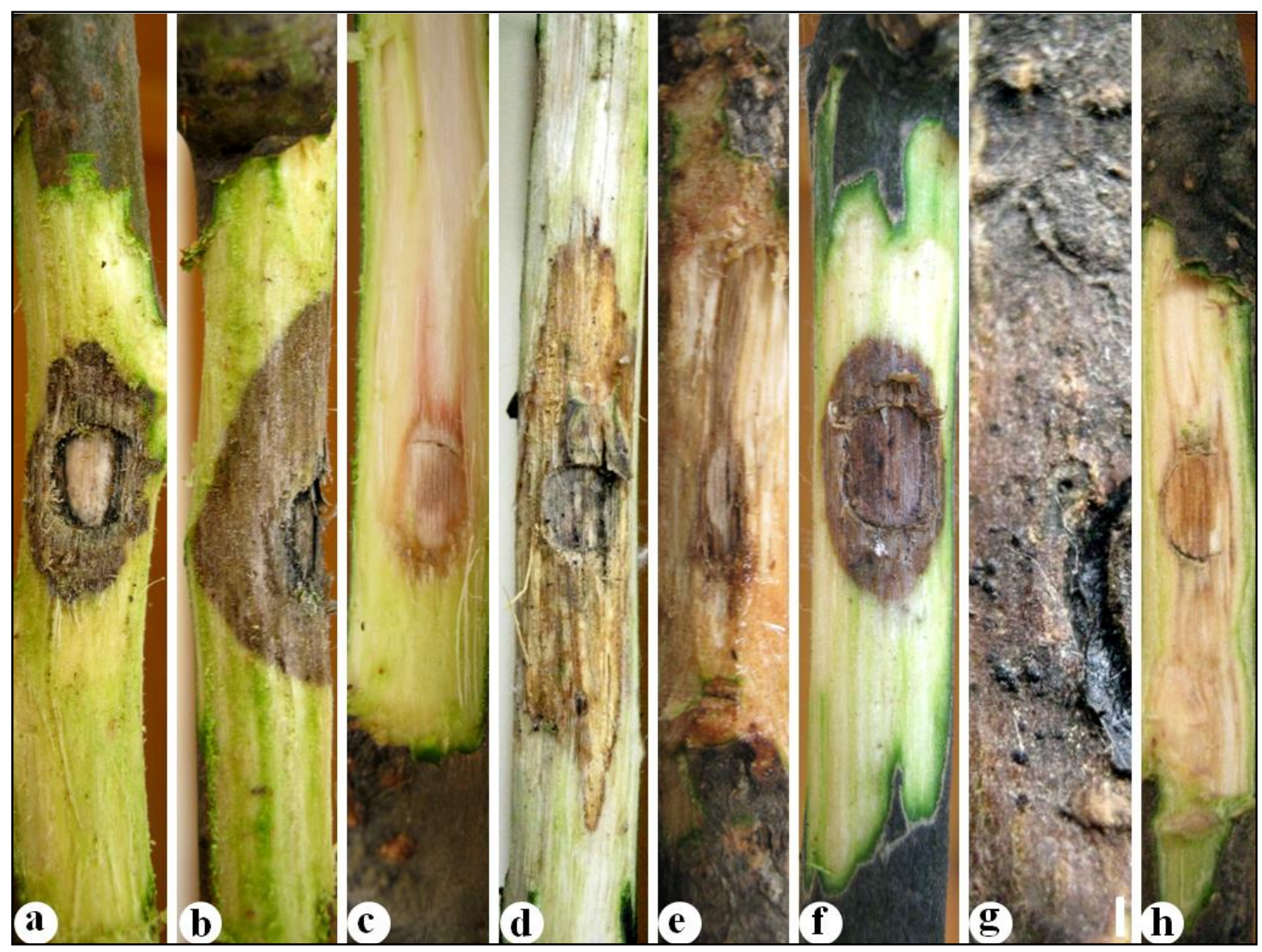


Figure S21. Signs and symptoms associated with Sphaeropsis visci on inoculated Viscum album branches. a. Necrotic lesion ; b. Pycnidia of S. visci formed in the dead branch tissue, exuding spores in white cirrhi; c. Pycnidia of $S$. visci formed in the dead leaf tissue; Control leaf inoculated with sterile WA plug; e. Control branch inoculated with sterile WA plug. Bars: $b=0.5 \mathrm{~cm}, \mathrm{c}=1 \mathrm{~cm}$.

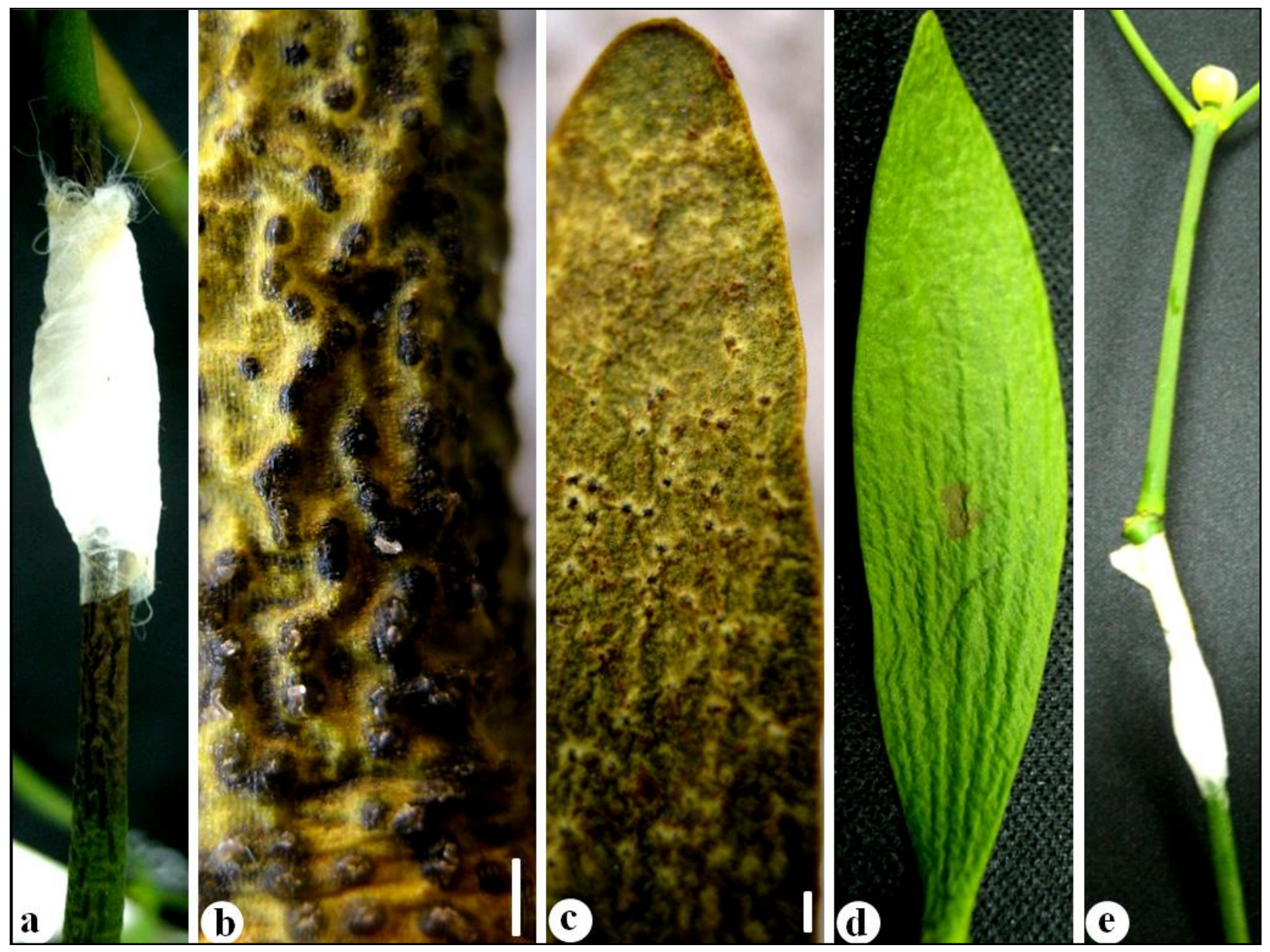


Figure S22. Signs and symptoms associated with Neofusicoccum parvum CMW 39317 on inoculated Prunus laurocerasus leaves.a. A hole in the leaf and necrotic lesion extending to cells beyond the hole, b. Necrotic lesion progressing from the inoculation point upwards and downwards, c. Necrotic lesion showing concentric rings and $N$. parvum pycnidia embedded within the lesion; d. Necrotic leaf with $N$. parvum pycnidia in the dead leaf tissue; e. Shoot die-back; f. Pycnidia of N. parvum produced in the dead shoot tissue. Bars: c, d, e= $1 \mathrm{~cm}$.

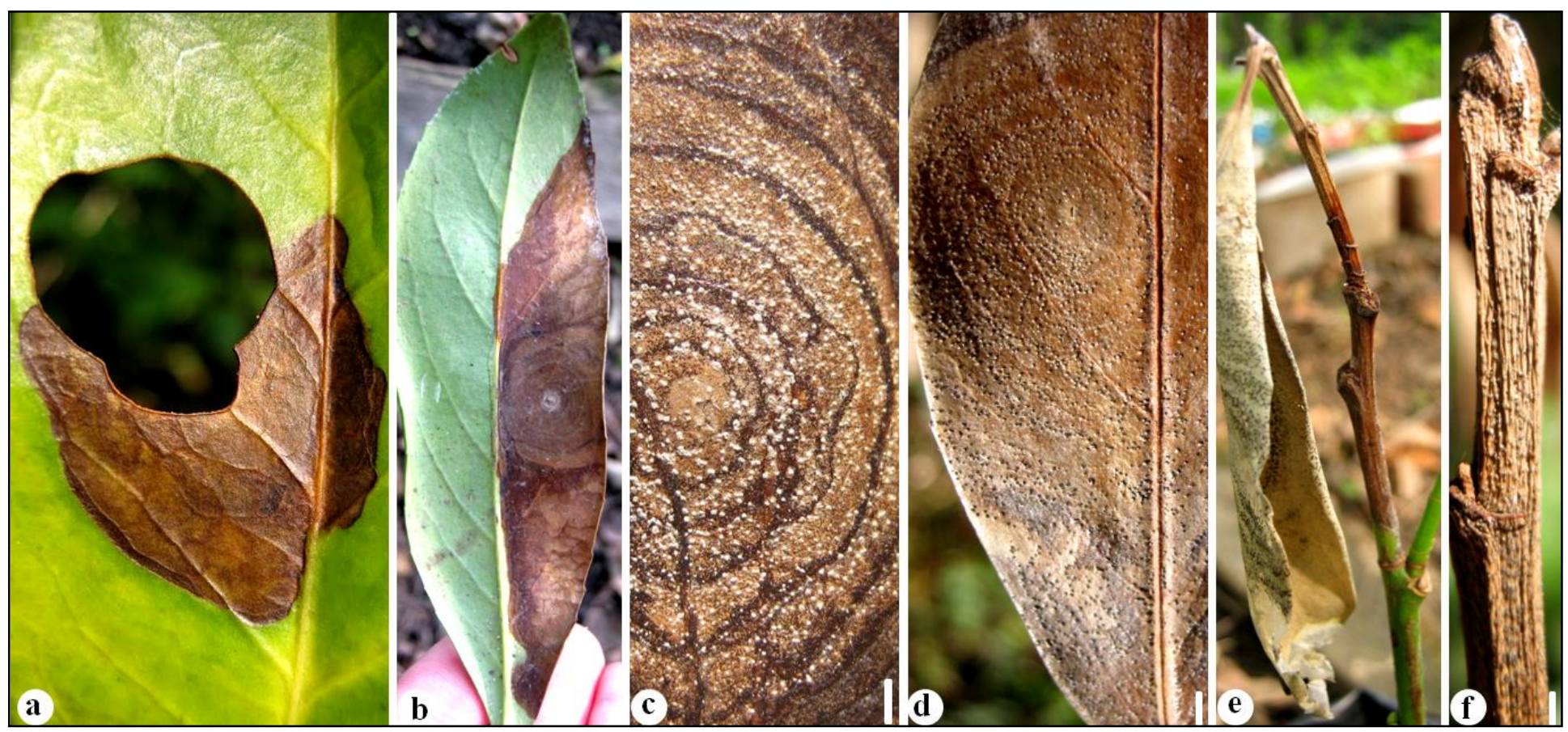


Figure S23. Signs and symptoms associated with Diplodia sapinea, Neofusicoccum parvum and Botryosphaeria dothidea on inoculated Pinus patula seedlings.a. Resin-soaked lesion associated with D. sapinea CMW 39329; b. resin bleeding associated with $D$. sapinea CMW 39329; c. Resinous lesion associated with N. parvum CMW 39317; d. Pycnidia of N. parvum produced after inoculation of P. patula with N. parvum CMW 39317; e. Resinous lesion associated with B. dothidea CMW 39301; f. Control seedling inoculated with sterile WA plug.

Bar: $\mathrm{d}=1 \mathrm{~cm}$. Data for D. sapinea were retreived from Zlatković et al. 2017 and serve for comparison with inoculations conducted with $N$. parvum and B. dothidea.

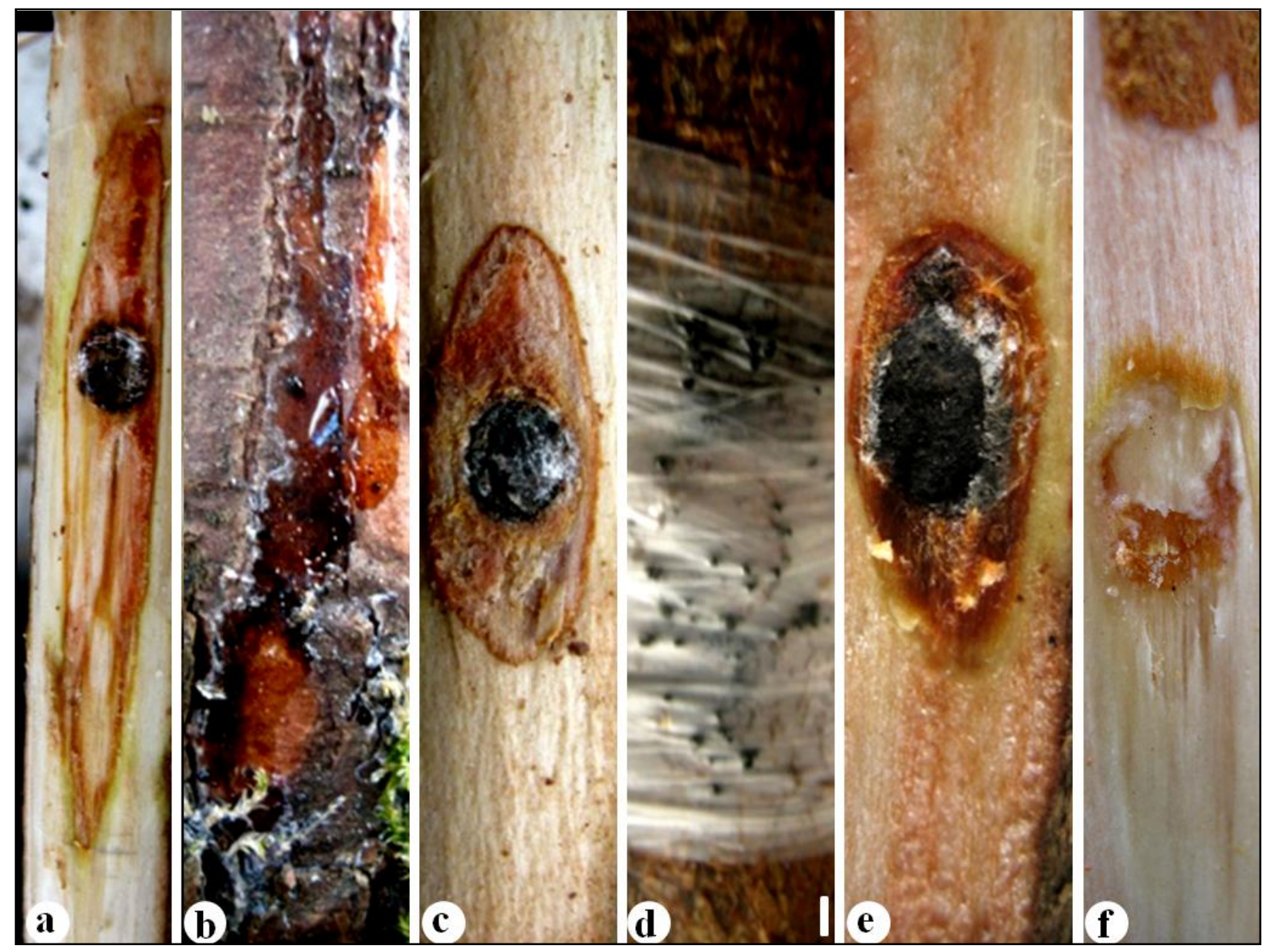


Figure S24. Signs and symptoms associated with Diplodia sapinea, Neofusicoccum parvum and Botryosphaeria dothidea on inoculated Eucalyptus grandis seedlings. a. Lesions associated with: a. N. parvum CMW 39317; b. N. parvum CMW 39327; c. B. dothidea CMW 39315; d. B. dothidea CMW 39301; e. D. sapinea CMW 39337; f. D. sapinea CMW 39329. c. Control seedling inoculated with sterile WA plug. Data for D. sapinea were retreived from Zlatković et al. 2017 and serve for comparison with inoculations conducted with N. parvum and B. dothidea.

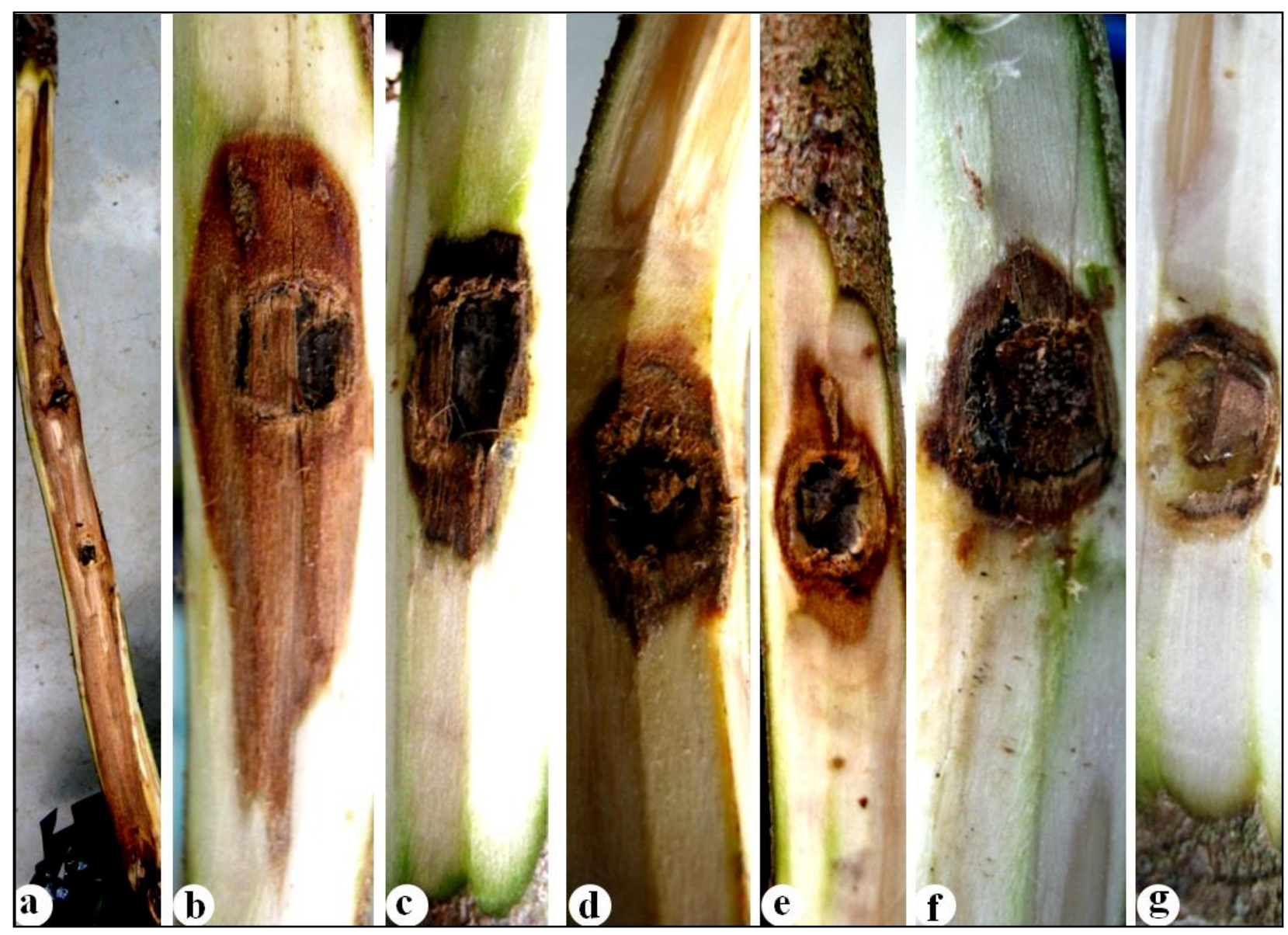


Table S1. Trees and shrubs from which Botryosphaeriaceae were isolated in this study. Shrubby species are given in bold.

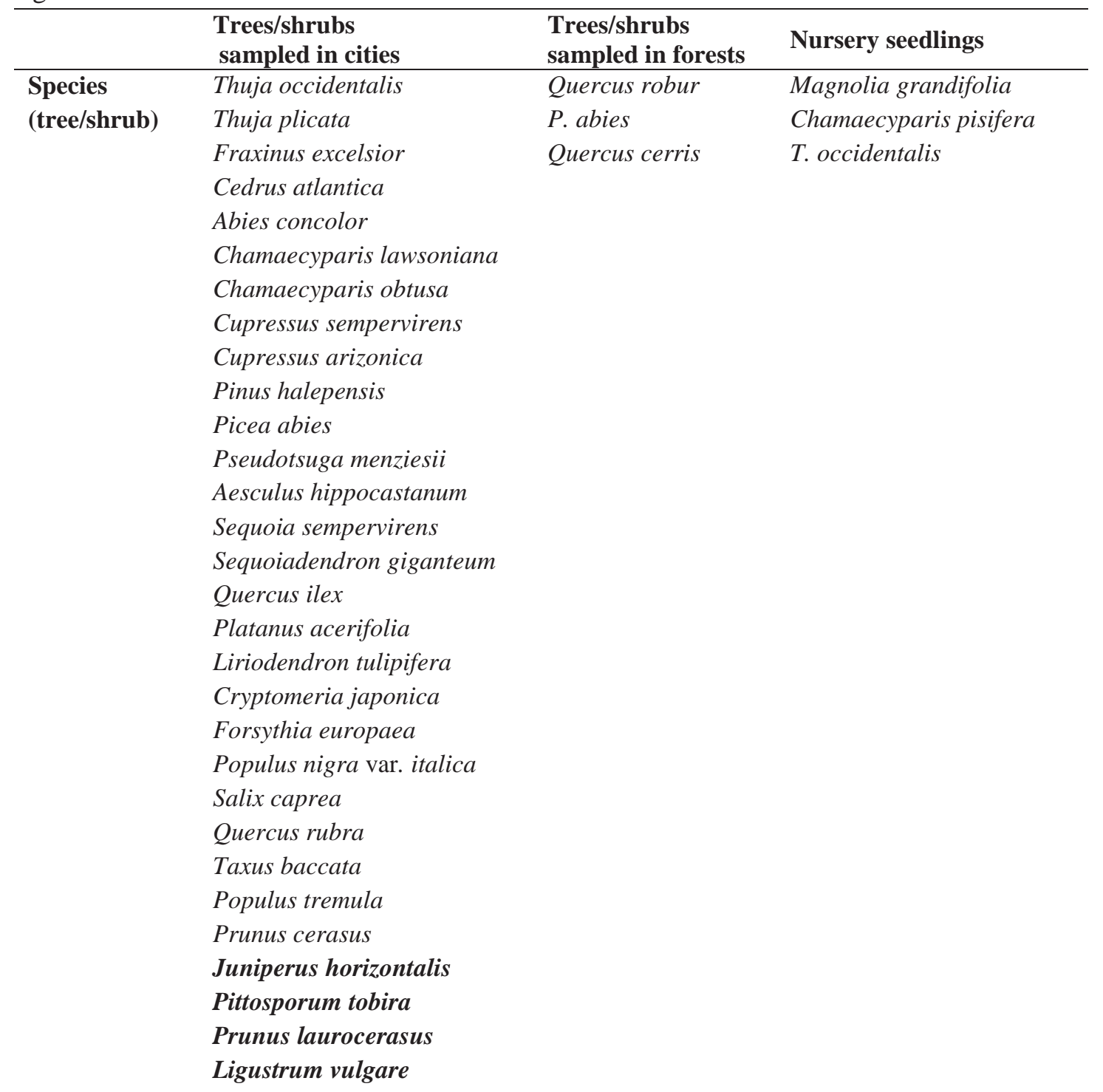

\begin{tabular}{|c|c|c|c|}
\hline $\begin{array}{l}\text { No. of } \\
\text { sampled } \\
\text { trees/shrubs }\end{array}$ & 85 & 4 & 4 \\
\hline
\end{tabular}


Table S2. Isolates used in the phylogenetic analyses.

\begin{tabular}{|c|c|c|c|c|c|c|c|c|}
\hline \multirow[b]{2}{*}{ Isolate } & \multirow[b]{2}{*}{ Identity } & \multirow[b]{2}{*}{ Host } & \multirow{2}{*}{ Location $^{1,2,3}$} & \multirow[b]{2}{*}{ Collector } & \multicolumn{4}{|c|}{ GenBank Accession } \\
\hline & & & & & ITS & EF1- $\alpha$ & $\beta$-tubulin & RPB2 \\
\hline CBS 112555 & Diplodia seriata & Vitis vinifera & Portugal & A. J. L. Phillips & AY259094 & AY573220 & DQ458856 & - \\
\hline CMW 39385 & D. seriata & Rubus fruticosus & Bosnia and Herzegovina ${ }^{1}$ & D. Karadžić & KF574991 & KF575023 & KF575087 & - \\
\hline CMW 39384 & D. seriata & Thuja occidentalis & Belgrade, Serbia & M. Zlatković & KF574992 & KF575024 & KF575088 & - \\
\hline CMW 39378 & D. seriata & Cedrus atlantica & Belgrade, Serbia & M. Zlatković & KF574994 & KF575031 & KF575090 & - \\
\hline CMW 39374 & D. seriata & Fraxinus excelsior & Bosnia and Herzegovina & D. Karadžić & KF574995 & KF575026 & KF575091 & - \\
\hline CMW 39376 & D. seriata & Chamaecyparis pisifera & Belgrade, Serbia ${ }^{2}$ & M. Zlatković & KF574996 & KF575027 & KF575092 & - \\
\hline CMW 39379 & D. seriata & Ligustrum vulgare & Belgrade, Serbia & M. Zlatković & KF574997 & KF575032 & KF575093 & - \\
\hline BOT 221 & D. seriata & C. atlantica & Belgrade, Serbia & M. Zlatković & KF729250 & - & - & - \\
\hline CMW 39380 & D. seriata & Abies concolor & Pirot, Serbia & M. Zlatković & KF729251 & КT987409 & - & - \\
\hline CMW 39381 & D. seriata & Chamaecyparis lawsoniana & Belgrade, Serbia & M. Zlatković & KF729252 & - & - & - \\
\hline BOT 247 & D. seriata & L. vulgare & Belgrade, Serbia & M. Zlatković & KF729253 & - & - & - \\
\hline BOT 158 & D. seriata & C. atlantica & Belgrade, Serbia & M. Zlatković & KF729254 & - & - & - \\
\hline BOT 231 & D. seriata & C. atlantica & Belgrade, Serbia & M. Zlatković & KF729255 & - & - & - \\
\hline CMW 39382 & D. seriata & Quercus robur & Morović, Serbia ${ }^{1}$ & M. Zlatković & KF729256 & KT987410 & - & - \\
\hline CMW 39383 & D. seriata & Thuja pilcata & Belgrade, Serbia & M. Zlatković & KF729257 & KT987411 & - & - \\
\hline ВOT 252 & D. seriata & T. occidentalis & Pirot, Serbia & M. Zlatković & KF729258 & - & - & - \\
\hline CMW 39375 & D. seriata & Cupressus sempervirens & Bijeljina, Bosnia and Herzegovina & D. Karadžić & KF729259 & KT987412 & - & - \\
\hline ВОT 193 & D. seriata & F. excelsior & Bosnia and Herzegovina & D. Karadžić & KF729260 & - & - & - \\
\hline BOT 219 & D. seriata & T. occidentalis & Belgrade, Serbia & M. Zlatković & KF729261 & - & - & - \\
\hline CMW 45092 & D. seriata & Salix caprea & Pirot, Serbia & M. Zlatković & KT964308 & - & - & - \\
\hline BOT 284 & D. seriata & S. caprea & Pirot, Serbia & M. Zlatković & KT964309 & - & - & - \\
\hline CMW 45094 & D. seriata & Quercus rubra & Belgrade, Serbia & M. Zlatković & KT964311 & - & - & - \\
\hline CMW 45099 & D. seriata & Prunus cerasus & Pirot, Serbia & M. Zlatković & KT964310 & - & - & - \\
\hline ВOT 304 & D. seriata & C. sempervirens & Belgrade, Serbia & M. Zlatković & KT964312 & - & - & - \\
\hline CBS 119049 & D. seriata & Vitis sp. & Italy & L. Mugnai & DQ458889 & DQ458874 & DQ458857 & - \\
\hline CBS 393.84 & Diplodia sapinea & Pinus nigra & Netherlands & H. A. van der Aa & DQ458895 & DQ458880 & DQ458863 & - \\
\hline CMW 39341 & D. sapinea & Cedrus deodara & Podgorica, Montenegro & M. Zlatković & KF574998 & KF575028 & KF575094 & - \\
\hline CMW 39346 & D. sapinea & Picea omorika & Belgrade, Serbia & M. Zlatković & KF575000 & KF575030 & KF575096 & - \\
\hline CMW 39338 & D. sapinea & C. atlantica & Belgrade, Serbia & M. Zlatković & KF574999 & KF575029 & KF575095 & - \\
\hline CMW 39336 & D. sapinea & Fagus sylvatica & Mt. Rudnik, Serbia ${ }^{1}$ & N. Keča & KF729247 & KF729481 & - & - \\
\hline CMW 39335 & D. sapinea & Pinus halepensis & Belgrade, Serbia & M. Zlatković & KF729170 & KF729404 & - & - \\
\hline CMW 39330 & D. sapinea & Juniperus horizontalis & Belgrade, Serbia & M. Zlatković & KF729173 & KF729407 & - & - \\
\hline CMW 39343 & D. sapinea & P. sylvestris & Niš, Serbia & M. Zlatković & KF729195 & KF729429 & - & - \\
\hline CMW 39345 & D. sapinea & Pinus pinea & Budva, Montenegro & M. Zlatković & KF729188 & KF729422 & - & - \\
\hline CMW 39344 & D. sapinea & Picea pungens & Niš, Serbia & M. Zlatković & KF729190 & KF729424 & - & - \\
\hline CMW 39342 & D. sapinea & A. concolor & Belgrade, Serbia & M. Zlatković & KF729199 & KF729433 & - & - \\
\hline CMW 39339 & D. sapinea & Pinus pinaster & Miločer, Montenegro & M. Zlatković & KF729205 & KF729439 & - & - \\
\hline
\end{tabular}




\begin{tabular}{|c|c|c|c|c|c|c|c|c|}
\hline \multirow{2}{*}{ Isolate } & \multirow{2}{*}{ Identity } & \multirow[b]{2}{*}{ Host } & \multirow{2}{*}{ Location $^{1,2,3}$} & \multirow[b]{2}{*}{ Collector } & \multicolumn{4}{|c|}{ GenBank Accession } \\
\hline & & & & & ITS & EF1- $\alpha$ & $\beta$-tubulin & RPB2 \\
\hline$\overline{\mathrm{CMW}} 39334$ & D. sapinea & Pseudotsuga menziesii & Belgrade, Serbia & M. Zlatković & KF729233 & KF729467 & - & - \\
\hline CMW 39332 & D. sapinea & P. nigra & Pirot, Serbia & M. Zlatković & KF729235 & KF729469 & - & - \\
\hline CMW 39331 & D. sapinea & Cedrus libani & Podgorica, Montenegro & M. Zlatković & KF729236 & KF729470 & - & - \\
\hline CMW 39333 & D. sapinea & C. lawsoniana & Herceg Novi, Montenegro & M. Zlatković & KF729239 & KF729473 & - & - \\
\hline CMW 39347 & D. sapinea & Pinus radiata & Mt. Athos, Greece ${ }^{3}$ & D. Karadžić & KT749856 & KT749858 & - & - \\
\hline CBS 109725 & D. sapinea & Pinus patula & South Africa & M. J. Wingfield & DQ458896 & DQ458881 & DQ458864 & - \\
\hline CBS 112556 & Diplodia intermedia & Malus domestica & Aveiro, Portugal & A. Alves & GQ923857 & GQ923850 & - & - \\
\hline CBS 124462 & D. intermedia & Malus sylvestris & Portugal & A. J. L. Phillips & GQ923858 & GQ923826 & - & - \\
\hline CBS 118110 & Diplodia scrobiculata & Pinus banksiana & USA & M. A. Palmer & KF766160 & AY624258 & AY624258 & - \\
\hline CBS 113423 & D. scrobiculata & Pinus greggii & Mexico & M. J. Wingfield & DQ458900 & DQ458885 & DQ458868 & - \\
\hline CBS 136014 & Diplodia mutila & Populus alba & Portugal & A. Alves & KJ361837 & KJ361829 & - & - \\
\hline CMW 39356 & D. mutila & Aesculus hippocastanum & Obrenovac, Serbia & D. Karadžić & KF575001 & KF575033 & KF575097 & - \\
\hline CMW 39354 & D. mutila & P. halepensis & Herceg Novi, Montenegro & M. Zlatković & KF575002 & KF575034 & KF575098 & - \\
\hline CMW 39353 & D. mutila & Cupressus arizonica & Herceg Novi, Montenegro & M. Zlatković & KF575003 & KF575035 & KF575099 & - \\
\hline CMW 39349 & D. mutila & Pittosporum tobira & Herceg Novi, Montenegro & M. Zlatković & KF729262 & - & - & - \\
\hline CMW 39351 & D. mutila & Chamaecyparis obtusa & Kanjiža, Serbia & N. Keča & KF729263 & - & - & - \\
\hline CMW 39357 & D. mutila & Sequoia sempervirens & Belgrade, Serbia & M. Zlatković & KF729264 & - & - & - \\
\hline BOT 129 & D. mutila & C. arizonica & Belgrade, Serbia & M. Zlatković & KF729265 & - & - & - \\
\hline BOT 105 & D. mutila & Prunus laurocerasus & Budva, Montenegro & M. Zlatković & KF729266 & - & - & - \\
\hline CMW 39352 & D. mutila & P. laurocerasus & Belgrade, Serbia & M. Zlatković & KF729267 & - & - & - \\
\hline CMW 39350 & D. mutila & C. lawsoniana & Belgrade, Serbia & M. Zlatković & KF729268 & - & - & - \\
\hline BOT 116 & D. mutila & P. laurocerasus & Belgrade, Serbia & M. Zlatković & KF729269 & - & - & - \\
\hline BOT 161 & D. mutila & C. lawsoniana & Herceg Novi, Montenegro & M. Zlatković & KF729270 & - & - & - \\
\hline CMW 39355 & D. mutila & C. atlantica & Belgrade, Serbia & M. Zlatković & KF729271 & - & - & - \\
\hline BOT 151 & D. mutila & P. laurocerasus & Belgrade, Serbia & M. Zlatković & KF729272 & - & - & - \\
\hline CMW 39358 & D. mutila & T. plicata & Belgrade, Serbia & M. Zlatković & KF729273 & - & - & - \\
\hline CMW 39348 & D. mutila & C. sempervirens & Herceg Novi, Montenegro & M. Zlatković & KF729274 & - & - & - \\
\hline BOT 218 & D. mutila & A. hippocastanum & Obrenovac, Serbia & D. Karadžić & KF729275 & - & - & - \\
\hline BOT 217 & D. mutila & C. atlantica & Herceg Novi, Montenegro & M. Zlatković & KF729276 & - & - & - \\
\hline CBS 112553 & D. mutila & V. vinifera & Portugal & A. J. L. Phillips & AY259093 & AY573219 & DQ458850 & - \\
\hline CBS 124133 & Diplodia subglobosa & Lonicera nigra & Spain & J. Luque & GQ923856 & GQ923824 & - & - \\
\hline CBS 124132 & D. subglobosa & F. excelsior & Spain & J. Luque & DQ458887 & DQ458871 & - & - \\
\hline CBS 122527 & Sphaeropsis visci & Viscum album & Ukraine & Á. Akulov & EU673327 & - & - & - \\
\hline CMW 39386 & S. visci & V. album & Mt Goč, Serbia ${ }^{1}$ & N. Keča & KF575004 & KF575036 & KF575100 & - \\
\hline CBS 100163 & S. visci & V. album & Luxemburg & H.A. van der Aa & EU673324 & EU673292 & EU673127 & - \\
\hline CBS 110496 & Sphaeropsis porosa & V. vinifera & South Africa & J. M. van Niekerk & AY343378 & AY343339 & EU673130 & - \\
\hline CBS 110574 & S. porosa & $V$. vinifera & South Africa & J. M. van Niekerk & AY343378 & AY343339 & - & - \\
\hline
\end{tabular}




\begin{tabular}{|c|c|c|c|c|c|c|c|c|}
\hline \multirow[b]{2}{*}{ Isolate } & \multirow[b]{2}{*}{ Identity } & \multirow[b]{2}{*}{ Host } & \multirow{2}{*}{ Location $^{1,2,3}$} & \multirow[b]{2}{*}{ Collector } & \multicolumn{4}{|c|}{ GenBank Accession } \\
\hline & & & & & ITS & EF1- $\alpha$ & $\beta$-tubulin & RPB2 \\
\hline IRAN 1458c & Phaeobotryon cupressi & Cupressus sempervirens & Gorgan, Iran & M. A. Aghajani & FJ919671 & FJ919660 & - & - \\
\hline CMW 39387 & P. cupressi & C. sempervirens & Podgorica, Montenegro & $\begin{array}{l}\text { M. Zlatković/ } \\
\text { J. Lazarević }\end{array}$ & KF575005 & KF575037 & KF575101 & - \\
\hline CBS 124700 & P. cupressi & C. sempervirens & Gorgan, Iran & M. A. Aghajani & FJ919672 & FJ919661 & - & - \\
\hline CBS 122980 & Phaeobotryon mamane & Sophora chrysophylla & Hawaii & W. Gams & EU673332 & EU673298 & EU673121 & - \\
\hline СРC 12445 & P. mamane & S. chrysophylla & Hawaii & W. Gams & EU673336 & EU673302 & EU673122 & - \\
\hline CMW 8000 & Botryosphaeria dothidea & Prunus sp. & Switzerland & B. Slippers & AY236949 & AY236898 & AY23692 & - \\
\hline CMW 39302 & B. dothidea & Pseudotsuga menziesii & Belgrade, Serbia & M. Zlatković & KF575006 & KF575038 & KF575102 & - \\
\hline CMW 39304 & B. dothidea & Sequoia sempervirens & Belgrade, Serbia & M. Zlatković & KF575007 & KF575039 & KF575103 & - \\
\hline CMW 39308 & B. dothidea & Sequoiadendron giganteum & Valjevo, Serbia & N. Keča & KF575008 & KF575040 & KF575104 & - \\
\hline BOT 45 & B. dothidea & C. atlantica & Belgrade, Serbia & M. Zlatković & KF729086 & - & - & - \\
\hline BOT 67 & B. dothidea & Quercus ilex & Podgorica, Montenegro & $\begin{array}{l}\text { J. Lazarević/ } \\
\text { M. Zlatković }\end{array}$ & KF729087 & - & - & - \\
\hline BOT 77 & B. dothidea & Q. ilex & Podgorica, Montenegro & $\begin{array}{l}\text { J. Lazarević/ } \\
\text { M. Zlatković }\end{array}$ & KF729088 & - & - & - \\
\hline BOT 48 & B. dothidea & Q. ilex & Podgorica, Montenegro & $\begin{array}{l}\text { J. Lazarević/ } \\
\text { M. Zlatković }\end{array}$ & KF729089 & - & - & - \\
\hline ВOT 19 & B. dothidea & C. lawsoniana & Belgrade, Serbia & $\begin{array}{l}\text { M. Zlatković/ } \\
\text { N. Keča }\end{array}$ & KF729090 & - & - & - \\
\hline BOT 46 & B. dothidea & T. plicata & Belgrade, Serbia & M. Zlatković & KF729091 & - & - & - \\
\hline ВОT 83 & B. dothidea & S. giganteum & Belgrade, Serbia & M. Zlatković & KF729092 & - & - & - \\
\hline CMW 39313 & B. dothidea & J. horizontalis & Budva, Montenegro & M. Zlatković & KF729093 & - & - & - \\
\hline BOT 278 & B. dothidea & S. giganteum & Belgrade, Serbia & M. Zlatković & KF729094 & - & - & - \\
\hline CMW 39310 & B. dothidea & Magnolia grandifolia & Belgrade, Serbia ${ }^{2}$ & N. Keča & KF729095 & - & - & - \\
\hline BOT 35 & B. dothidea & S. giganteum & Belgrade, Serbia & M. Zlatković & KF729096 & - & - & - \\
\hline ВОТ88 & B. dothidea & S. sempervirens & Belgrade, Serbia & M. Zlatković & KF729097 & - & - & - \\
\hline BOT 37 & B. dothidea & C. atlantica & Belgrade, Serbia & M. Zlatković & KF729098 & - & - & - \\
\hline CMW 39314 & B. dothidea & Picea abies & Mt. Goč, Serbia ${ }^{1}$ & D. Karadžić & KF729099 & - & - & - \\
\hline ВOT 74 & B. dothidea & P. menziesii & Belgrade, Serbia & M. Zlatković & KF729100 & - & - & - \\
\hline BOT 134 & B. dothidea & C. atlantica & Bar, Montenegro & M. Zlatković & KF729101 & - & - & - \\
\hline BOT 4 & B. dothidea & S. giganteum & Valjevo, Serbia & N. Keča & KF729102 & - & - & - \\
\hline BOT 24 & B. dothidea & Platanus acerifolia & Bosnia and Herzegovina & D. Karadžić & KF729103 & - & - & - \\
\hline BOT 21 & B. dothidea & S. sempervirens & Belgrade, Serbia & M. Zlatković & KF729104 & - & - & - \\
\hline CMW 39311 & B. dothidea & T. occidentalis & Belgrade, Serbia & M. Zlatković & KF729105 & - & - & - \\
\hline BOT 34 & B. dothidea & S. giganteum & Belgrade, Serbia & $\begin{array}{l}\text { M. Zlatković/ } \\
\text { I. Milenković }\end{array}$ & KF729106 & - & - & - \\
\hline BOT 18 & B. dothidea & C. atlantica & Belgrade, Serbia & M. Zlatković & KF729107 & - & - & - \\
\hline ВOT 86 & B. dothidea & S. giganteum & Valjevo, Serbia & N. Keča & KF729108 & - & - & - \\
\hline BOT 40 & B. dothidea & S. giganteum & Valjevo, Serbia & N. Keča & KF729109 & - & - & - \\
\hline
\end{tabular}




\begin{tabular}{|c|c|c|c|c|c|c|c|c|}
\hline \multirow{2}{*}{ Isolate } & \multirow{2}{*}{ Identity } & \multirow{2}{*}{ Host } & \multirow{2}{*}{ Location $^{1,2,3}$} & \multirow{2}{*}{ Collector } & \multicolumn{4}{|c|}{ GenBank Accession } \\
\hline & & & & & ITS & EF1- $\alpha$ & $\beta$-tubulin & RPB2 \\
\hline$\overline{\text { BOT } 85}$ & B. dothidea & S. giganteum & Valjevo, Serbia & N. Keča & KF729110 & - & - & - \\
\hline CMW 39312 & B. dothidea & P. acerifolia & Bosnia and Herzegovina & D. Karadžić & KF729111 & - & - & - \\
\hline ВOT 32 & B. dothidea & S. giganteum & Belgrade, Serbia & M. Zlatković & KF729485 & - & - & - \\
\hline BOT 52 & B. dothidea & C. lawsoniana & Belgrade, Serbia & N. Keča & KF729112 & - & - & - \\
\hline BOT 124 & B. dothidea & C. lawsoniana & Belgrade, Serbia & N. Keča & KF729113 & - & - & - \\
\hline BOT 58 & B. dothidea & C. atlantica & Belgrade, Serbia & M. Zlatković & KF729114 & - & - & - \\
\hline BOT 61 & B. dothidea & C. lawsoniana & Belgrade, Serbia & N. Keča & KF729115 & - & - & - \\
\hline BOT 224 & B. dothidea & T. plicata & Belgrade, Serbia & M. Zlatković & KF729116 & - & - & - \\
\hline BOT 120 & B. dothidea & S. giganteum & Belgrade, Serbia & M. Zlatković & KF729117 & - & - & - \\
\hline CMW 39309 & B. dothidea & A. concolor & Belgrade, Serbia & M. Zlatković & KF729118 & - & - & - \\
\hline ВОТ 80 & B. dothidea & T. plicata & Belgrade, Serbia & M. Zlatković & KF729119 & - & - & - \\
\hline CMW 39305 & B. dothidea & Q. ilex & Podgorica, Montenegro & $\begin{array}{l}\text { J. Lazarević/ } \\
\text { M. Zlatković }\end{array}$ & KF729120 & - & - & - \\
\hline BOT 91 & B. dothidea & S. giganteum & Belgrade, Serbia & M. Zlatković & KF729121 & - & - & - \\
\hline BOT 168 & B. dothidea & S. giganteum & Belgrade, Serbia & M. Zlatković & KF729122 & - & - & - \\
\hline ВОТ 99 & B. dothidea & S. giganteum & Belgrade, Serbia & M. Zlatković & KF729123 & - & - & - \\
\hline BOT 122 & B. dothidea & C. atlantica & Belgrade, Serbia & M. Zlatković & KF729124 & - & - & - \\
\hline ВOT 156 & B. dothidea & P. menziesii & Belgrade, Serbia & M. Zlatković & KF729125 & - & - & - \\
\hline CMW 39307 & B. dothidea & T. plicata & Belgrade, Serbia & $\begin{array}{l}\text { M. Zlatković/ } \\
\text { I. Milenković }\end{array}$ & KF729126 & - & - & - \\
\hline BOT 178 & B. dothidea & S. giganteum & Belgrade, Serbia & M. Zlatković & KF729127 & - & - & - \\
\hline BOT 2 & B. dothidea & C. atlantica & Belgrade, Serbia & M. Zlatković & KF729128 & - & - & - \\
\hline CMW 39315 & B. dothidea & C. lawsoniana & Bar, Montenegro & M. Zlatković & KF729129 & - & - & - \\
\hline ВOT 110 & B. dothidea & S. giganteum & Valjevo, Serbia & N. Keča & KF729130 & - & - & - \\
\hline BOT 66 & B. dothidea & C. lawsoniana & Belgrade, Serbia & N. Keča & KF729131 & - & - & - \\
\hline BOT 176 & B. dothidea & C. lawsoniana & Morović, Serbia & M. Zlatković & KF729132 & - & - & - \\
\hline BOT 68 & B. dothidea & S. sempervirens & Belgrade, Serbia & M. Zlatković & KF729133 & - & - & - \\
\hline BOT 81 & B. dothidea & T. plicata & Belgrade, Serbia & M. Zlatković & KF729134 & - & - & - \\
\hline BOT 175 & B. dothidea & T. plicata & Belgrade, Serbia & M. Zlatković & KF729135 & - & - & - \\
\hline BOT 190 & B. dothidea & S. giganteum & Belgrade, Serbia & M. Zlatković & KF729136 & - & - & - \\
\hline BOT 44 & B. dothidea & A. hippocastanum & Obrenovac, Serbia & D. Karadžić & KF729137 & - & - & - \\
\hline BOT 70 & B. dothidea & S. giganteum & Belgrade, Serbia & M. Zlatković & KF729138 & - & - & - \\
\hline ВOT 121 & B. dothidea & Q. ilex & Podgorica, Montenegro & $\begin{array}{l}\text { J. Lazarević/ } \\
\text { M. Zlatković }\end{array}$ & KF729139 & - & - & - \\
\hline
\end{tabular}




\begin{tabular}{|c|c|c|c|c|c|c|c|c|}
\hline \multirow{2}{*}{ Isolate } & \multirow{2}{*}{ Identity } & \multirow{2}{*}{ Host } & \multirow{2}{*}{ Location $^{1,2,3}$} & \multirow{2}{*}{ Collector } & \multicolumn{4}{|c|}{ GenBank Accession } \\
\hline & & & & & ITS & EF1- $\alpha$ & $\beta$-tubulin & RPB2 \\
\hline$\overline{\text { BOT } 118}$ & B. dothidea & C. atlantica & Belgrade, Serbia & $\begin{array}{l}\text { N. Keča/ } \\
\text { M. Zlatković }\end{array}$ & KF729140 & - & - & - \\
\hline BOT 106 & B. dothidea & S. giganteum & Belgrade, Serbia & M. Zlatković & KF729141 & - & - & - \\
\hline ВOT 92 & B. dothidea & S. giganteum & Belgrade, Serbia & M. Zlatković & KF729142 & - & - & - \\
\hline BOT 108 & B. dothidea & C. atlantica & Belgrade, Serbia & M. Zlatković & KF729143 & - & - & - \\
\hline BOT 111 & B. dothidea & C. lawsoniana & Belgrade, Serbia & N. Keča & KF729144 & - & - & - \\
\hline BOT 263 & B. dothidea & S. sempervirens & Belgrade, Serbia & M. Zlatković & KF729145 & - & - & - \\
\hline BOT 53 & B. dothidea & A. concolor & Belgrade, Serbia & M. Zlatković & KF729146 & - & - & - \\
\hline CMW 39301 & B. dothidea & C. lawsoniana & Belgrade, Serbia & M. Zlatković & KF729147 & - & - & - \\
\hline ВOT 213 & B. dothidea & C. lawsoniana & Belgrade, Serbia & N. Keča & KF729148 & - & - & - \\
\hline BOT 73 & B. dothidea & P. menziesii & Belgrade, Serbia & M. Zlatković & KF729149 & - & - & - \\
\hline BOT 41 & B. dothidea & C. atlantica & Belgrade, Serbia & M. Zlatković & KF729150 & - & - & - \\
\hline BOT 72 & B. dothidea & P. menziesii & Belgrade, Serbia & M. Zlatković & KF729151 & - & - & - \\
\hline BOT 47 & B. dothidea & S. giganteum & Valjevo, Serbia & N. Keča & KF729152 & - & - & - \\
\hline ВOT 93 & B. dothidea & S. sempervirens & Belgrade, Serbia & M. Zlatković & KF729153 & - & - & - \\
\hline BOT 75 & B. dothidea & Q. ilex & Podgorica, Montenegro & $\begin{array}{l}\text { J. Lazarević/ } \\
\text { M. Zlatković }\end{array}$ & KF729154 & - & - & - \\
\hline CMW 39306 & B. dothidea & Liriodendron tulipifera & Belgrade, Serbia & $\begin{array}{l}\text { D. Karadžić/ } \\
\text { I. Milenković }\end{array}$ & KF729155 & - & - & - \\
\hline BOT 78 & B. dothidea & C. lawsoniana & Belgrade, Serbia & M. Zlatković & KF729156 & - & - & - \\
\hline CMW 39298 & B. dothidea & C. atlantica & Belgrade, Serbia & M. Zlatković & KF729157 & - & - & - \\
\hline BOT 215 & B. dothidea & C. atlantica & Bar, Montenegro & M. Zlatković & KF729158 & - & - & - \\
\hline BOT 181 & B. dothidea & S. giganteum & Valjevo, Serbia & N. Keča & KF729159 & - & - & - \\
\hline BOT 94 & B. dothidea & C. lawsoniana & Belgrade, Serbia & M. Zlatković & KF729160 & - & - & - \\
\hline CMW 39300 & B. dothidea & C. sempervirens & Podgorica, Montenegro & $\begin{array}{l}\text { M. Zlatković/ } \\
\text { J. Lazarević }\end{array}$ & KF729161 & - & - & - \\
\hline BOT 166 & B. dothidea & C. lawsoniana & Bar, Montenegro & M. Zlatković & KF729162 & - & - & - \\
\hline ВОТ 76 & B. dothidea & C. arizonica & Herceg Novi, Montenegro & M. Zlatković & KF729163 & - & - & - \\
\hline CMW 39303 & B. dothidea & C. arizonica & Belgrade, Serbia & M. Zlatković & KF729164 & - & - & - \\
\hline ВОT 216 & B. dothidea & C. atlantica & Belgrade, Serbia & M. Zlatković & KF729165 & - & - & - \\
\hline CMW 39299 & B. dothidea & A. hippocastanum & Obrenovac, Serbia & D. Karadžić & KF729166 & - & - & - \\
\hline BOT 165 & B. dothidea & C. atlantica & Belgrade, Serbia & M. Zlatković & KF729167 & - & - & - \\
\hline ВОТ 9 & B. dothidea & S. sempervirens & Belgrade, Serbia & M. Zlatković & KF729168 & - & - & - \\
\hline BOT 262 & B. dothidea & S. sempervirens & Belgrade, Serbia & M. Zlatković & KF729169 & - & - & - \\
\hline CMW 45089 & B. dothidea & Populus nigra var. italica & Vršac, Serbia & N. Keča & КТ964313 & - & - & - \\
\hline CMW 45091 & B. dothidea & Salix caprea & Pirot, Serbia & M. Zlatković & КT964320 & - & - & - \\
\hline BOT 283 & B. dothidea & S. caprea & Pirot, Serbia & M. Zlatković & КТ964314 & - & - & - \\
\hline CMW 45096 & B. dothidea & Taxus baccata & Belgrade, Serbia & M. Zlatković & КT964315 & - & - & - \\
\hline
\end{tabular}




\begin{tabular}{|c|c|c|c|c|c|c|c|c|}
\hline \multirow{2}{*}{ Isolate } & \multirow{2}{*}{ Identity } & \multirow[b]{2}{*}{ Host } & \multirow{2}{*}{ Location $1,2,3$} & \multirow[b]{2}{*}{ Collector } & \multicolumn{4}{|c|}{ GenBank Accession } \\
\hline & & & & & ITS & EF1- $\alpha$ & $\beta$-tubulin & RPB2 \\
\hline$\overline{C M W ~ 45097}$ & B. dothidea & Populus tremula & Belgrade, Serbia & M. Zlatković & KT964322 & - & - & - \\
\hline BOT 298 & B. dothidea & P. tremula & Belgrade, Serbia & M. Zlatković & KT964323 & - & - & - \\
\hline CMW 45098 & B. dothidea & Quercus cerris & Mt. Suva, Serbia ${ }^{1}$ & N. Keča & КT964316 & - & - & - \\
\hline BOT 300 & B. dothidea & Q. cerris & Mt. Suva, Serbia ${ }^{1}$ & N. Keča & КT964317 & - & - & - \\
\hline BOT 302 & B. dothidea & C. lawsoniana & Belgrade, Serbia & M. Zlatković & KT964318 & - & - & - \\
\hline BOT 305 & B. dothidea & J. horizontalis & Pirot, Serbia & M. Zlatković & KT964321 & - & - & - \\
\hline BOT 306 & B. dothidea & J. horizontalis & Pirot, Serbia & M. Zlatković & КT964319 & - & - & - \\
\hline MUCC 501 & B. dothidea & Eucalyptus marginata & Yalgorup, Australia & K. M. Taylor & EF591916 & EF591969 & EF591952 & - \\
\hline ATCC 22927 & Botryosphaeria corticis & Vaccinium sp. & USA & R. D. Millholland & DQ299247 & EU673291 & EU673108 & - \\
\hline CBS 119047 & B. corticis & Vaccinium corymbosum & New Jersey, USA & P. V. Oudemans & DQ299245 & EU017539 & EU673107 & - \\
\hline IMI 63581b & Dothiorella sarmentorum & Ulmus sp. & England & E. A. Ellis & AY573212 & AY573235 & EU673102 & - \\
\hline CMW 39366 & Do. sarmentorum & A. hippocastanum & Belgrade, Serbia & I. Milenković & KF575009 & KF575047 & KF575105 & - \\
\hline CMW 39364 & Do. sarmentorum & C. lawsoniana & Belgrade, Serbia & M. Zlatković & KF575010 & KF575048 & KF575106 & - \\
\hline CMW 39370 & Do. sarmentorum & C. atlantica & Belgrade, Serbia & M. Zlatković & KF575011 & KF575049 & KF575107 & - \\
\hline CMW 39369 & Do. sarmentorum & Cryptomeria japonica & Belgrade, Serbia & M. Zlatković & KF729075 & - & - & - \\
\hline CMW 39368 & Do. sarmentorum & Forsythia europaea & Belgrade, Serbia & M. Zlatković & KF729076 & - & - & - \\
\hline CMW 39367 & Do. sarmentorum & T. plicata & Belgrade, Serbia & M. Zlatković & KF729077 & - & - & - \\
\hline BOT 144 & Do. sarmentorum & T. occidentalis & Belgrade, Serbia & M. Zlatković & KF729078 & - & - & - \\
\hline BOT 195 & Do. sarmentorum & C. atlantica & Belgrade, Serbia & M. Zlatković & KF729080 & - & - & - \\
\hline BOT 173 & Do. sarmentorum & T. occidentalis & Pirot, Serbia & M. Zlatković & KF729081 & - & - & - \\
\hline CMW 39365 & Do. sarmentorum & T. occidentalis & Pirot, Serbia & M. Zlatković & KF729079 & - & - & - \\
\hline CMW 45095 & Do. sarmentorum & Q. rubra & Belgrade, Serbia & S. Milanović & & - & - & - \\
\hline CBS 115038 & Do. sarmentorum & Malus pumila & The Netherlands & A. J. L. Phillips & AY573206 & AY573223 & EU673101 & - \\
\hline CBS 128309 & Dothiorella americana & $V$. vinifera & Missouri, USA & $\begin{array}{l}\text { K. Striegler/ } \\
\text { G. M. Leavitt }\end{array}$ & HQ288218 & HQ288262 & HQ288297 & - \\
\hline CBS 128310 & Do. americana & V. vinifera & Missouri, USA & $\begin{array}{l}\text { K. Striegler/ } \\
\text { G. M. Leavitt }\end{array}$ & HQ288219 & HQ288263 & HQ288298 & - \\
\hline CBS 124716 & Dothiorella omnivora & Juglans regia & Iran & $\begin{array}{l}\text { J. Abdollahzadeh/ } \\
\text { A. Javadi }\end{array}$ & KC898232 & KC898215 & - & - \\
\hline CBS 124717 & Do. omnivora & J. regia & Iran & $\begin{array}{l}\text { J. Abdollahzadeh/ } \\
\text { A. Javadi }\end{array}$ & КС898233 & КС898216 & - & - \\
\hline CMW 39360 & Do. omnivora & Fraxinus excelsior & Bosnia and Herzegovina & D. Karadžić & KF575012 & KF575052 & KF575108 & - \\
\hline CMW 39361 & Do. omnivora & C. sempervirens & Podgorica, Montenegro & M. Zlatković & KF729083 & KT253576 & KT253570 & - \\
\hline CMW 39362 & Do. omnivora & Thuja occidentalis & Belgrade, Serbia & M. Zlatković & KF575013 & KF575053 & KF575109 & - \\
\hline CMW 39363 & Do. omnivora & C. lawsoniana & Belgrade, Serbia & M. Zlatković & KF575014 & KF575054 & KF575110 & - \\
\hline BOT 177 & Do. omnivora & S. giganteum & Belgrade, Serbia & M. Zlatković & KF729082 & - & - & - \\
\hline CMW 39359 & Do. omnivora & S. giganteum & Belgrade, Serbia & M. Zlatković & KF729084 & - & - & - \\
\hline
\end{tabular}




\begin{tabular}{|c|c|c|c|c|c|c|c|c|}
\hline \multirow[b]{2}{*}{ Isolate } & \multirow[b]{2}{*}{ Identity } & \multirow[b]{2}{*}{ Host } & \multirow{2}{*}{ Location ${ }^{1,2,3}$} & \multirow[b]{2}{*}{ Collector } & \multicolumn{4}{|c|}{ GenBank Accession } \\
\hline & & & & & ITS & EF1- $\alpha$ & $\beta$-tubulin & RPB2 \\
\hline CBS 135622 & Dothiorella sp. & C. atlantica & Belgrade, Serbia & M. Zlatković & KF261725 & KF261729 & KF261731 & - \\
\hline $\begin{array}{l}\text { MFLUCC13- } \\
0497\end{array}$ & Dothiorella sp. & Symphoricarpos sp. & Italy & Erio Camporesi & KJ742378 & KJ742381 & - & - \\
\hline $\begin{array}{l}\text { MFLUCC13- } \\
0498\end{array}$ & Dothiorella sp. & Symphoricarpos sp. & Italy & Erio Camporesi & KJ742379 & KJ742382 & - & - \\
\hline DAR 78992 & Dothiorella vidmadera & V. vinifera & Eden Valley, Australia & $\begin{array}{l}\text { W. M. Pitt/ } \\
\text { A. Loschiavo }\end{array}$ & EU768874 & EU768881 & HM800522 & - \\
\hline DAR 78993 & Do. vidmadera & V. vinifera & Loxton, Australia & $\begin{array}{l}\text { W. M. Pitt/ } \\
\text { A. Loschiavo }\end{array}$ & EU768876 & EU768882 & HM800523 & - \\
\hline CBS 115041 & Dothiorella iberica & Q. ilex & Aragón, Spain & J. Luque & AY573202 & AY573222 & EU673096 & - \\
\hline CBS 113188 & Do. iberica & Quercus suber & Andalucia, Spain & M. E. Sánchez & AY573198 & EU673278 & EU673097 & - \\
\hline JL 599 & Dothiorella parva & Corylus avelana & Spain & J. Luque & EU673314 & EU673281 & EU673099 & - \\
\hline CBS124720 & Do. parva & C. avelana & Iran, Ardabil & $\begin{array}{l}\text { J. Abdollahzadeh } \\
\text { / A. Javadi }\end{array}$ & KC898234 & KC898217 & - & - \\
\hline CBS 124719 & Dothiorella sempervirentis & C. sempervirens & Iran, Golestan & M. A. Aghajani & KC898237 & KC898220 & - & - \\
\hline CBS 124718 & Do. sempervirentis & C. sempervirens & Iran, Golestan & M. A. Aghajani & KC898236 & КС898219 & - & - \\
\hline MUCC 507 & Dothiorella moneti & Acacia rostellifera & Yalgorup, Australia & K. M. Taylor & EF591922 & EF591973 & EF591956 & - \\
\hline MUCC 505 & Do. moneti & A.rostellifera & Yalgorup, Australia & K. M. Taylor & EF591920 & EF591971 & EF591954 & - \\
\hline CMW 9081 & Neofusicoccum parvum & Populus nigra & New Zealand & G. J. Samuels & AY236943 & AY236888 & AY236917 & - \\
\hline CMW 39328 & N. parvum & Pittosporum tobira & Herceg Novi, Montenegro & M. Zlatković & KF575017 & KF575041 & KF575113 & KF729318 \\
\hline CMW 39321 & N. parvum & Prunus laurocerasus & Budva, Montenegro & M. Zlatković & KF575018 & KF575042 & KF575114 & KF729319 \\
\hline CMW 39326 & N. parvum & Eucalyptus globulus & Herceg Novi, Montenegro & M. Zlatković & KF575019 & KF575043 & KF575115 & KF729320 \\
\hline CMW 39325 & N. parvum & A. hippocastanum & Belgrade, Serbia & I. Milenković & KF575021 & KF575045 & KF575117 & KF729322 \\
\hline CMW 39318 & N. parvum & C. lawsoniana & Belgrade, Serbia & $\begin{array}{l}\text { N. Keča/ } \\
\text { M. Zlatković }\end{array}$ & KF575022 & KF575046 & KF575118 & KF729323 \\
\hline BOT 107 & N. parvum & S. giganteum & Belgrade, Serbia & M. Zlatković & KF729034 & KF729364 & KF729324 & KF729277 \\
\hline ВОт 3 & N. parvum & S. giganteum & Belgrade, Serbia & M. Zlatković & KF729035 & KF729365 & KF729325 & KF729278 \\
\hline BOT 15 & N. parvum & S. giganteum & Belgrade, Serbia & M. Zlatković & KF729036 & KF729366 & KF729326 & KF729279 \\
\hline ВОТ 49 & N. parvum & C. lawsoniana & Belgrade, Serbia & M. Zlatković & KF729037 & KF729367 & KF729327 & KF729280 \\
\hline ВOT 79 & N. parvum & C. atlantica & Belgrade, Serbia & M. Zlatković & KF729038 & KF729368 & KF729328 & KF729281 \\
\hline ВОт 6 & N. parvum & A. hippocastanum & Belgrade, Serbia & I. Milenković & KF729039 & KF729369 & KF729329 & KF729282 \\
\hline ВОT 275 & N. parvum & P. laurocerasus & Belgrade, Serbia & M. Zlatković & KF729040 & KF729370 & KF729330 & KF729283 \\
\hline CMW 39323 & N. parvum & C. obtusa & Kanjiža, Serbia & N. Keča & KF729041 & KF729371 & KF729331 & KF729284 \\
\hline BOT 267 & N. parvum & A. hippocastanum & Obrenovac, Serbia & D. Karadžić & KF729042 & KF729372 & KF729332 & KF729285 \\
\hline CMW 39320 & N. parvum & S. sempervirens & Belgrade, Serbia & M. Zlatković & KF729043 & KF729373 & KF729333 & KF729286 \\
\hline BOT 87 & N. parvum & S. giganteum & Belgrade, Serbia & M. Zlatković & KF729044 & KF729374 & KF729334 & KF729287 \\
\hline CMW 39324 & N. parvum & C. pisifera & Belgrade, Serbia ${ }^{2}$ & M. Zlatković & KF729045 & KF729375 & KF729335 & KF729288 \\
\hline ВОT 90 & N. parvum & C. lawsoniana & Belgrade, Serbia & M. Zlatković & KF729046 & KF729376 & KF729336 & KF729289 \\
\hline
\end{tabular}




\begin{tabular}{|c|c|c|c|c|c|c|c|c|}
\hline \multirow{2}{*}{ Isolate } & \multirow{2}{*}{ Identity } & \multirow{2}{*}{ Host } & \multirow{2}{*}{ Location $^{1,2,3}$} & \multirow{2}{*}{ Collector } & \multicolumn{4}{|c|}{ GenBank Accession } \\
\hline & & & & & ITS & EF1- $\alpha$ & $\beta$-tubulin & RPB2 \\
\hline$\overline{\text { CMW } 39322}$ & N. parvum & P. abies & Niš, Serbia & M. Zlatković & KF729047 & KF729377 & KF729337 & KF729290 \\
\hline BOT 43 & N. parvum & C. atlantica & Belgrade, Serbia & M. Zlatković & KF729048 & KF729378 & KF729338 & KF729291 \\
\hline ВОТ 82 & N. parvum & S. giganteum & Belgrade, Serbia & M. Zlatković & KF729049 & KF729379 & KF729339 & KF729292 \\
\hline CMW 39327 & N. parvum & S. giganteum & Belgrade, Serbia & M. Zlatković & KF729050 & KF729380 & KF729340 & KF729293 \\
\hline BOT 42 & N. parvum & T. occidentalis & Belgrade, Serbia ${ }^{2}$ & M. Zlatković & KF729051 & KF729381 & KF729341 & KF729294 \\
\hline BOT 59 & N. parvum & S. giganteum & Belgrade, Serbia & M. Zlatković & KF729052 & KF729382 & KF729342 & KF729295 \\
\hline BOT 136 & N. parvum & C. atlantica & Herceg Novi, Montenegro & M. Zlatković & KF729053 & KF729383 & KF729343 & KF729296 \\
\hline CMW 39319 & N. parvum & T. occidentalis & Belgrade, Serbia $^{2}$ & M. Zlatković & KF729054 & KF729384 & KF729344 & KF729297 \\
\hline BOT 281 & N. parvum & A. hippocastanum & Belgrade, Serbia & M. Zlatković & KF729055 & KF729385 & KF729345 & KF729298 \\
\hline BOT 64 & N. parvum & S. giganteum & Kumane, Serbia & N. Keča & KF729056 & KF729386 & KF729346 & KF729299 \\
\hline BOT 112 & N. parvum & S. giganteum & Valjevo, Serbia & N. Keča & KF729057 & KF729387 & KF729347 & KF729300 \\
\hline BOT 113 & N. parvum & S. giganteum & Valjevo, Serbia & N. Keča & KF729058 & KF729388 & KF729348 & KF729301 \\
\hline BOT 214 & N. parvum & S. giganteum & Belgrade, Serbia & M. Zlatković & KF729059 & KF729389 & KF729349 & KF729302 \\
\hline BOT 17 & N. parvum & S. giganteum & Belgrade, Serbia & M. Zlatković & KF729060 & KF729390 & KF729350 & KF729303 \\
\hline BOT 16 & N. parvum & S. giganteum & Belgrade, Serbia & M. Zlatković & KF729062 & KF729392 & KF729352 & KF729305 \\
\hline CMW 39316 & N. parvum & P. halepensis & Herceg Novi, Montenegro & M. Zlatković & KF729061 & KF729391 & KF729351 & KF729304 \\
\hline BOT 160 & N. parvum & S. giganteum & Belgrade, Serbia & M. Zlatković & KF729063 & KF729393 & KF729353 & KF729306 \\
\hline ВOT 26 & N. parvum & A. hippocastanum & Obrenovac, Serbia & D. Karadžić & KF729064 & KF729394 & KF729354 & KF729307 \\
\hline BOT 1 & N. parvum & S. giganteum & Kumane, Serbia & N. Keča & KF729065 & KF729395 & KF729355 & KF729308 \\
\hline ВОТ 39 & N. parvum & S. giganteum & Valjevo, Serbia & N. Keča & KF729066 & KF729396 & KF729356 & KF729309 \\
\hline BOT 27 & N. parvum & S. giganteum & Belgrade, Serbia & M. Zlatković & KF729067 & KF729397 & KF729357 & KF729310 \\
\hline BOT 131 & N. parvum & P. laurocerasus & Belgrade, Serbia & M. Zlatković & KF729068 & KF729398 & KF729358 & KF729311 \\
\hline BOT 13 & N. parvum & S. giganteum & Kumane, Serbia & N. Keča & KF729069 & KF767529 & KF729484 & KF729312 \\
\hline BOT 30 & N. parvum & S. giganteum & Belgrade, Serbia & M. Zlatković & KF729070 & KF729399 & KF729359 & KF729313 \\
\hline ВОT 8 & N. parvum & S. giganteum & Kumane, Serbia & N. Keča & KF729071 & KF729400 & KF729360 & KF729314 \\
\hline BOT 11 & N. parvum & S. giganteum & Valjevo, Serbia & N. Keča & KF729072 & KF729401 & KF729361 & KF729315 \\
\hline BOT 286 & N. parvum & C. lawsoniana & Belgrade, Serbia & M. Zlatković & KF729073 & KF729402 & KF729362 & KF729316 \\
\hline BOT 14 & N. parvum & S. giganteum & Kumane, Serbia & N. Keča & KF729074 & KF729403 & KF729363 & KF729317 \\
\hline CMW 45090 & N. parvum & P. nigra var. italica & Vršac, Serbia & N. Keča & KT964325 & - & - & - \\
\hline CMW 45093 & N. parvum & Q. rubra & Belgrade, Serbia & S. Milanović & КT964326 & - & - & - \\
\hline BOT 288 & N. parvum & A. hippocastanum & Belgrade, Serbia & M. Zlatković & KT964327 & - & - & - \\
\hline ВОТ 289 & N. parvum & A. hippocastanum & Belgrade, Serbia & M. Zlatković & KT964328 & - & - & - \\
\hline BOT 290 & N. parvum & A. hippocastanum & Belgrade, Serbia & M. Zlatković & KT964329 & - & - & - \\
\hline ВOT 291 & N. parvum & A. hippocastanum & Belgrade, Serbia & M. Zlatković & KT964332 & - & - & - \\
\hline ВОТ 292 & N. parvum & A. hippocastanum & Belgrade, Serbia & M. Zlatković & КT964330 & - & - & - \\
\hline ВОТ 293 & N. parvum & A. hippocastanum & Belgrade, Serbia & M. Zlatković & КT964333 & - & - & - \\
\hline BOT 301 & N. parvum & C. lawsoniana & Belgrade, Serbia & M. Zlatković & KT964331 & - & - & - \\
\hline
\end{tabular}




\begin{tabular}{|c|c|c|c|c|c|c|c|c|}
\hline \multirow{2}{*}{ Isolate } & \multirow{2}{*}{ Identity } & \multirow{2}{*}{ Host } & \multirow{2}{*}{ Location 1, 2, 3} & \multirow{2}{*}{ Collector } & \multicolumn{4}{|c|}{ GenBank Accession } \\
\hline & & & & & ITS & EF1- $\alpha$ & $\beta$-tubulin & RPB2 \\
\hline$\overline{\mathrm{CMW}} 9071$ & N. parvum & Ribes sp. & Australia & M. J. Wingfield & EU339552 & AY236880 & AY236909 & - \\
\hline CBS 123639 & $\begin{array}{l}\text { Neofusicoccum } \\
\text { kwambonambiense }\end{array}$ & S. cordatum & South Africa & D. Pavlic & EU821900 & EU821870 & EU821840 & - \\
\hline CBS 123641 & N. kwambonambiense & S. cordatum & South Africa & D. Pavlic & EU821919 & EU821889 & EU821859 & - \\
\hline CMW 14054 & Neofusicoccum cordaticola & S. cordatum & South Africa & D. Pavlic & EU821906 & EU821876 & EU821846 & - \\
\hline CMW 13992 & N. cordaticola & S. cordatum & South Africa & D. Pavlic & EU821898 & EU821868 & EU821838 & - \\
\hline CBS 117448 & Pseudofusicoccum stromaticum & Eucalyptus hybrid & Venezuela & S. Mohali & AY693974 & AY693975 & EU673094 & - \\
\hline CBS 117449 & P. stromaticum & Eucalyptus hybrid & Venezuela & S. Mohali & DQ436935 & DQ436936 & EU673093 & - \\
\hline
\end{tabular}

Culture collections: CMW: FABI, University of Pretoria, South Africa; CBS: Centraalbureau voor Schimmelcultures, Utrecht, The Netherlands; CPC: Collection of Pedro Crous housed at CBS; IRAN: Iranian Fungal Culture Collection, Iranian Research Institute of Plant Protection, Iran; ATCC, American Type Culture Collection; MUCC: Murdoch University Culture Collection; DAR: Plant Pathology Herbarium, Orange Agricultural Institute, DPI, Orange, NSW, Australia; IMI: CABI Genetic Resource Collection Bioscience, Egham, Surrey, United Kingdom; JL: J. Luque, IRTA, Barcelona, Spain; MFLUCC: Mae Fah Luang University Culture Collection, Chiang Rai, Thailand. Isolates sequenced in this study are given in bold. Other sequences were retrieved from GenBank. Isolate accession numbers in italics signify cultures linked morphologically to the type material. ${ }^{1}$ Forest stand, ${ }^{2}$ Nursery, ${ }^{3}$ Forest plantation. 
Table S3. Symptoms observed on various tree species and Botryosphaeriaceae species involved in the development of symptoms.

\begin{tabular}{|c|c|c|c|c|c|c|c|c|c|c|c|c|c|}
\hline \multirow[b]{2}{*}{ Host } & \multirow{2}{*}{$\begin{array}{l}\text { Resin } \\
\text { bleeding }\end{array}$} & \multicolumn{3}{|c|}{ Necrosis/Canker } & \multicolumn{2}{|c|}{ Die-back } & \multirow{2}{*}{$\begin{array}{c}\text { Bark } \\
\text { cracking }\end{array}$} & \multirow{2}{*}{$\begin{array}{c}\text { Wood } \\
\text { discoloration }\end{array}$} & \multicolumn{4}{|c|}{ Fruit bodies } & \multirow{2}{*}{$\begin{array}{l}\text { Botryosphaeriaceae } \\
\text { species }^{2}\end{array}$} \\
\hline & & $\begin{array}{l}\text { Needles } \\
\text { /Leaves }\end{array}$ & Branch & Stem & Shoot & Stem & & & Cone & Stem & Branch & $\begin{array}{l}\text { Needles/ } \\
\text { Leaves }\end{array}$ & \\
\hline Cedrus atlantica & + & + & + & + & + & + & + & & & & + & & N. parvum \\
\hline C. deodara ${ }^{1}$ & + & & & + & & + & + & & & & & & - (D. sapinea $)$ \\
\hline C. libani & + & & & + & & + & + & & & & & & l \\
\hline $\begin{array}{l}\text { Chamaecyparis } \\
\text { lawsoniana }\end{array}$ & + & + & + & + & + & + & + & + & + & + & + & & B. dothidea \\
\hline C. obtusa & & + & & & + & + & & & & & & & l \\
\hline C. pisifera & & + & & & & + & & & & & & & l \\
\hline Thuja occidentalis & + & + & + & + & + & + & + & + & & + & + & & $\begin{array}{l}\text { B. dothidea, N. parvum, } \\
\text { D. seriata, } \\
\text { Do. sarmentorum }\end{array}$ \\
\hline T. plicata & + & + & + & + & + & + & & + & & & + & & 1 \\
\hline $\begin{array}{l}\text { Sequoiadendron } \\
\text { giganteum }\end{array}$ & + & + & & & + & + & + & + & & & & & $\begin{array}{l}\text { B. dothidea, N. parvum, } \\
\text { Do. omnivora }\end{array}$ \\
\hline Sequoia sempervirens & & + & & & + & & & & & & & & / \\
\hline Pseudotsuga menziesii ${ }^{1}$ & + & + & + & + & & & + & & & & & & D. sapinea \\
\hline Pinus spp. ${ }^{1}$ & + & + & + & + & + & + & & + & + & & & + & D. sapinea \\
\hline Abies concolor ${ }^{1}$ & + & + & + & + & + & + & + & + & & & & & $\begin{array}{l}\text { B. dothidea, D. seriata, } \\
\text { D. sapinea }\end{array}$ \\
\hline Picea abies & + & + & + & & + & + & & & & & & & B. dothidea, N. parvum \\
\hline P. pungens ${ }^{1}$ & + & + & + & & + & + & & & & & & & D. sapinea \\
\hline P. omorika ${ }^{1}$ & + & + & + & & + & + & & + & & & & & D. sapinea \\
\hline C. sempervirens & + & + & + & + & + & + & + & + & + & & & & $\begin{array}{l}\text { B. dothidea, D. seriata, } \\
\text { D. mutila }\end{array}$ \\
\hline C. arizonica & + & + & + & & + & & + & + & & & & & B. dothidea, D. mutila \\
\hline Cryptomeria japonica & & + & & & + & & & & & & & & / \\
\hline Juniperus horizontalis $^{1}$ & & + & & & + & + & & & & & & & B. dothidea, D. sapinea \\
\hline
\end{tabular}




\begin{tabular}{|c|c|c|c|c|c|c|c|c|c|c|c|c|c|}
\hline \multirow[b]{2}{*}{ Host } & \multirow{2}{*}{$\begin{array}{l}\text { Resin } \\
\text { bleeding }\end{array}$} & \multicolumn{3}{|c|}{ Necrosis/Canker } & \multicolumn{2}{|c|}{ Die-back } & \multirow{2}{*}{$\begin{array}{l}\text { Bark } \\
\text { cracking }\end{array}$} & \multirow{2}{*}{$\begin{array}{c}\text { Wood } \\
\text { discoloration }\end{array}$} & \multicolumn{4}{|c|}{ Fruit bodies } & \multirow{2}{*}{$\begin{array}{l}\text { Botryosphaeriaceae } \\
\text { species }\end{array}$} \\
\hline & & $\begin{array}{c}\text { Needles/ } \\
\text { Leaves }\end{array}$ & Branch & Stem & Shoot & Stem & & & Cone & Stem & Branch & $\begin{array}{c}\text { Needles/ } \\
\text { Leaves }\end{array}$ & \\
\hline Prunus laurocerasus & $\begin{array}{l}\text { gum } \\
\text { exudation }\end{array}$ & + & + & + & + & + & + & + & & & + & + & D. mutila, N. parvum \\
\hline P. cerasus & $\begin{array}{l}\text { gum } \\
\text { exudation }\end{array}$ & & + & + & + & + & + & + & & & & & $-(D$. seriata $)$ \\
\hline Ligustrum vulgare & & & + & + & + & + & & & & + & + & & D. seriata \\
\hline Forsythia europaea & & & & & + & & & & & & & & / \\
\hline Magnolia grandiflora & & & & & + & + & & & & & & & B. dothidea \\
\hline Liriodendron tulipifera & & & & & + & + & & & & & & & B. dothidea \\
\hline Aesculus hippocastanum & $\begin{array}{l}\text { black sap } \\
\text { exudation }\end{array}$ & & + & + & & & & & & & & & $\begin{array}{l}\text { B. dothidea, } \\
\text { N. parvum, D. mutila, } \\
\text { Do. sarmentorum }\end{array}$ \\
\hline Platanus acerifolia & & & & + & & & & & & & & & - (B. dothidea) \\
\hline Quercus robur & & & & + & & & & & & & & & D. seriata \\
\hline Q. ilex & & & & & + & + & & & & + & + & & / \\
\hline Q. rubra & & & & & + & + & & & & & & & $\begin{array}{l}\text { - (N. parvum, D. } \\
\text { seriata, Do. } \\
\text { sarmentorum })\end{array}$ \\
\hline Q. cerris & & & & + & & & + & & & & & & B. dothidea \\
\hline Pittosporum tobira & & & & & + & + & & & & & & & N. parvum \\
\hline Rubus fruticosus & & & & & + & + & & & & & & & I \\
\hline Fagus sylvatica $^{1}$ & & & & + & & & & + & & & & & D. sapinea \\
\hline Viscum album & & & & & & & & & & + & & + & S. visci \\
\hline Populus nigra var. italica & & & & & + & & & & & & + & & N. parvum \\
\hline Salix caprea & & & & & + & + & & + & & + & + & & / \\
\hline Taxus baccata & & & + & & & & & & & & & & - (B. dothidea) \\
\hline Fraxinus excelsior & & & + & & & & & & & & & & D. seriata \\
\hline Eucalyptus globulus & $\begin{array}{l}\text { black kino } \\
\text { exudation }\end{array}$ & & & + & & & + & & & & & & / \\
\hline P. tremula & & & & + & & & + & & & & & & B. dothidea \\
\hline
\end{tabular}


${ }^{1}$ Data retreived from Zlatković et al. 2017, ${ }^{2}$ Botryosphaeriaceae species involved in the development of symptoms: / Pathogenicity tests were not conducted,

- Botryosphaeriaceae species produced lesions which were not significantly larger from those observed on control plants and thus it is assumed that Botryosphaeriaceae were not involved in the development of symptoms. Data refer to the whole set of Botryosphaeriaceae isolates from the Western Balkans region, including isolates from this and from previous studies (Zlatković et al. 2016a, b, 2017). 
Table S4. Average temperatures and precipitation in Belgrade during pathogenicity evaluation (www.hidmet.gov.rs).

\begin{tabular}{|c|c|c|}
\hline Month/Year & Average Temperature $\left({ }^{\circ} \mathbf{C}\right)$ & Average Precipitation (mm) \\
\hline April 2014 & $13.7^{2, *}$ & $85.3^{7, *}$ \\
\hline May 2014 & $17.2^{1, *}$ & $280.4^{8, *}$ \\
\hline June 2014 & $21.4^{2, *}$ & $60.3^{5, *}$ \\
\hline July 2014 & $23^{2, *}$ & $250.6^{8, *}$ \\
\hline August 2014 & $22.5^{2, *}$ & $63.5^{6, *}$ \\
\hline September 2014 & $18.3^{1, *}$ & $126^{8, *}$ \\
\hline October 2014 & $14.1^{2, *}$ & $61.2^{7, *}$ \\
\hline April 2015 & $13.5^{2, *}$ & $30.7^{4, *}$ \\
\hline May 2015 & $19^{2, *}$ & $80.7^{6, *}$ \\
\hline June 2015 & $21.9^{2, *}$ & $38.6^{5, *}$ \\
\hline April 2016 & $15.5^{3, \#}$ & $58.7^{6, \#}$ \\
\hline May 2016 & $17.5^{1, \#}$ & $82.9^{7, \#}$ \\
\hline June 2016 & $22.5^{2, \#}$ & $134.2^{7, \#}$ \\
\hline
\end{tabular}


Table S5. Tree species and Botryosphaeriaceae isolates used for seedling and branch inoculations.

\begin{tabular}{|c|c|c|c|c|c|c|c|c|c|c|c|c|c|c|c|c|}
\hline \multirow{2}{*}{$\begin{array}{l}\text { Inoculated } \\
\text { species }\end{array}$} & \multicolumn{2}{|c|}{ B. dothidea } & \multicolumn{2}{|c|}{ N. parvum } & \multicolumn{2}{|c|}{ D. mutila } & \multicolumn{2}{|c|}{ D. seriata } & \multicolumn{2}{|c|}{$\begin{array}{c}\text { Do. } \\
\text { sarmentorum }\end{array}$} & \multicolumn{2}{|c|}{ Dothiorella sp. } & \multicolumn{2}{|c|}{ Do. omnivora } & \multirow{2}{*}{$\begin{array}{l}\text { S. visci } \\
\text { CMW } \\
39386 \\
\end{array}$} & \multirow{2}{*}{$\begin{array}{c}\begin{array}{c}P . \\
\text { cupressi }\end{array} \\
\text { CMW } \\
39387 \\
\end{array}$} \\
\hline & $\begin{array}{l}\text { CMW } \\
39301 \\
\end{array}$ & $\begin{array}{l}\text { CMW } \\
39315 \\
\end{array}$ & $\begin{array}{l}\text { CMW } \\
39327 \\
\end{array}$ & $\begin{array}{l}\text { CMW } \\
39317 \\
\end{array}$ & $\begin{array}{l}\text { CMW } \\
39348 \\
\end{array}$ & $\begin{array}{l}\text { CMW } \\
39385 \\
\end{array}$ & $\begin{array}{l}\text { CMW } \\
39376 \\
\end{array}$ & $\begin{array}{l}\text { CMW } \\
39382 \\
\end{array}$ & $\begin{array}{l}\text { CMW } \\
39364 \\
\end{array}$ & $\begin{array}{l}\text { CMW } \\
39365 \\
\end{array}$ & $\begin{array}{l}\text { CBS } \\
135622\end{array}$ & $\begin{array}{l}\text { CBS } \\
135623\end{array}$ & $\begin{array}{l}\text { CMW } \\
39361 \\
\end{array}$ & $\begin{array}{l}\text { CMW } \\
39363 \\
\end{array}$ & & \\
\hline $\begin{array}{l}\text { Cedrus atlantica } \\
\text { Cedrus deodara }\end{array}$ & + & + & $\begin{array}{l}+ \\
+\end{array}$ & + & + & + & + & + & + & + & + & + & & & & \\
\hline $\begin{array}{l}\text { Cupressus } \\
\text { arizonica }\end{array}$ & + & + & & & + & + & & & & & & & & & & \\
\hline $\begin{array}{l}\text { Picea omorika } \\
\text { Picea abies }\end{array}$ & + & + & $\begin{array}{l}+ \\
+\end{array}$ & + & & & & & & & & & & & & \\
\hline Abies concolor & + & + & & & & & + & + & & & & & & & & \\
\hline $\begin{array}{l}\text { Pseudotsuga } \\
\text { menziesii }\end{array}$ & + & + & & & & & & & & & & & & & & \\
\hline $\begin{array}{l}\text { Liriodendron } \\
\text { tulipifera }\end{array}$ & + & + & & & & & & & & & & & & & & \\
\hline $\begin{array}{l}\text { Ligustrum } \\
\text { vulgare }\end{array}$ & & & & & & & + & + & & & & & & & & \\
\hline $\begin{array}{l}\text { Juniperus } \\
\text { horizontalis }\end{array}$ & + & + & & & & & & & & & & & & & & \\
\hline $\begin{array}{l}\text { Chamaecyparis } \\
\text { lawsoniana }\end{array}$ & + & + & + & + & + & + & + & + & + & + & + & + & + & + & + & + \\
\hline $\begin{array}{l}\text { Thuja } \\
\text { occidentalis }\end{array}$ & + & + & + & + & & & + & + & + & + & & & & & & \\
\hline $\begin{array}{l}\text { Prunus } \\
\text { laurocerasus }{ }^{1}\end{array}$ & & & + & + & + & + & & & & & & & & & & \\
\hline Quercus robur & & & & & & & + & + & & & & & & & & \\
\hline $\begin{array}{l}\text { Pittosporum } \\
\text { tobira }\end{array}$ & & & + & + & + & + & & & & & & & & & & \\
\hline $\begin{array}{l}\text { Sequoiadendron } \\
\text { giganteum }\end{array}$ & + & + & + & + & & & & & & & & & + & + & & \\
\hline $\begin{array}{l}\text { Magnolia } \\
\text { grandifolia }\end{array}$ & + & + & & & & & & & & & & & & & & \\
\hline $\begin{array}{l}\text { Cupressus } \\
\text { sempervirens }\end{array}$ & + & + & & & + & + & + & + & & & & & + & + & & + \\
\hline $\begin{array}{l}\text { Forsythia } \\
\text { europaea }\end{array}$ & & & & & & & & & + & + & & & & & & \\
\hline
\end{tabular}


Table S5. Continued.

\begin{tabular}{|c|c|c|c|c|c|c|c|c|c|c|c|c|c|c|c|c|}
\hline \multirow{2}{*}{$\begin{array}{l}\text { Inoculated } \\
\text { species }\end{array}$} & \multicolumn{2}{|c|}{ B. dothidea } & \multicolumn{2}{|c|}{ N. parvum } & \multicolumn{2}{|c|}{ D. mutila } & \multicolumn{2}{|c|}{ D. seriata } & \multicolumn{2}{|c|}{$\begin{array}{c}\text { Do. } \\
\text { sarmentorum }\end{array}$} & \multicolumn{2}{|c|}{ Dothiorella sp. } & \multicolumn{2}{|c|}{ Do. omnivora } & \multirow{2}{*}{$\begin{array}{l}\text { S.visci } \\
\text { CMW } \\
39386\end{array}$} & \multirow{2}{*}{\begin{tabular}{c}
\multicolumn{1}{c}{$P}$. \\
cupressi \\
CMW \\
39387
\end{tabular}} \\
\hline & $\begin{array}{l}\text { CMW } \\
39301\end{array}$ & $\begin{array}{l}\text { CMW } \\
39315\end{array}$ & $\begin{array}{l}\text { CMW } \\
39327\end{array}$ & $\begin{array}{l}\text { CMW } \\
39317\end{array}$ & $\begin{array}{l}\text { CMW } \\
39348\end{array}$ & $\begin{array}{l}\text { CMW } \\
39385\end{array}$ & $\begin{array}{l}\text { CMW } \\
39376\end{array}$ & $\begin{array}{l}\text { CMW } \\
39382\end{array}$ & $\begin{array}{l}\text { CMW } \\
39364\end{array}$ & $\begin{array}{l}\text { CMW } \\
39365\end{array}$ & $\begin{array}{l}\text { CBS } \\
135622\end{array}$ & $\begin{array}{l}\text { CBS } \\
135623\end{array}$ & $\begin{array}{l}\text { CMW } \\
39361\end{array}$ & $\begin{array}{l}\text { CMW } \\
39363\end{array}$ & & \\
\hline Taxus baccata & + & + & & & & & & & & & & & & & & \\
\hline Prunus cerasus & & & & & & & + & + & & & & & & & & \\
\hline Populus nigra & + & + & + & + & & & & & & & & & & & & \\
\hline Quercus rubra & & & + & + & & & + & + & + & + & & & & & & \\
\hline $\begin{array}{l}\text { Platanus } \\
\text { acerifolia }\end{array}$ & + & + & & & & & & & & & & & & & & \\
\hline Pinus patula ${ }^{2}$ & + & + & + & + & & & & & & & & & & & & \\
\hline $\begin{array}{l}\text { Eucalyptus }{ }^{2} \\
\text { grandis }\end{array}$ & + & + & + & + & & & & & & & & & & & & \\
\hline $\begin{array}{l}\text { Aesculus } \\
\text { hippocastanum }^{3}\end{array}$ & + & + & + & + & + & + & & & + & + & & & & & & \\
\hline Populus tremula ${ }^{3}$ & + & + & & & & & & & & & & & & & & \\
\hline Quercus cerris $^{3}$ & + & + & & & & & & & & & & & & & & \\
\hline $\begin{array}{l}\text { Fraxinus } \\
\text { excelsior }\end{array}$ & & & & & & & + & + & & & & & + & + & & \\
\hline Viscum album $^{3}$ & & & & & & & & & & & & & - & & + & \\
\hline
\end{tabular}


Table S6. Details of the tree species inoculated in the field trial and in the greenhouse.

\begin{tabular}{|c|c|c|c|c|}
\hline Species & $\begin{array}{c}\text { Age } \\
\text { (years) }\end{array}$ & $\begin{array}{l}\text { Mean stem diameter } \\
(\mathrm{cm})\end{array}$ & $\begin{array}{l}\text { Mean height } \\
(\mathrm{cm})\end{array}$ & $\begin{array}{l}\text { Cork borer } \\
(\mathrm{mm})^{2}\end{array}$ \\
\hline Cedrus atlantica & 2 & 0.9 & 17 & 3 \\
\hline Cedrus deodara & 2 & 0.9 & 17 & 3 \\
\hline Cupressus arizonica & 3 & 1.3 & 39 & 6 \\
\hline Picea omorika & 2 & 0.9 & 18 & 3 \\
\hline Picea abies & 3 & 1.4 & 29 & 6 \\
\hline Abies concolor & 2 & 1.2 & 20 & 6 \\
\hline Pseudotsuga menziesii & 2 & 0.9 & 18 & 3 \\
\hline Liriodendron tulipifera & 3 & 1.5 & 32 & 6 \\
\hline Ligustrum vulgare & 3 & 1.2 & 32 & 6 \\
\hline Juniperus horizontalis & 2 & 0.9 & 14 & 3 \\
\hline Chamaecyparis lawsoniana & 3 & 1.5 & 36 & 6 \\
\hline Thuja occidentalis & 3 & 1.5 & 35 & 6 \\
\hline Prunus laurocerasus & 2 & 1.3 & 22 & 6 \\
\hline Quercus robur & 3 & 1.2 & 29 & 6 \\
\hline Pittosporum tobira & 3 & 1.2 & 25 & 6 \\
\hline Sequoiadendron giganteum & 2 & 0.9 & 18 & 3 \\
\hline Magnolia grandifolia & 2 & 1.2 & 16 & 3 \\
\hline Cupressus sempervirens & 2 & 0.9 & 19 & 3 \\
\hline Forsythia europaea & 3 & 1.4 & 39 & 6 \\
\hline Taxus baccata & 2 & 1.3 & 29 & 6 \\
\hline Prunus cerasus & 2 & 1.5 & 40 & 6 \\
\hline Populus nigra var. italica & 2 & 1.2 & 18 & 3 \\
\hline Quercus rubra & 2 & 1.2 & 21 & 3 \\
\hline Platanus acerifolia & 2 & 1.2 & 20 & 3 \\
\hline Pinus patula ${ }^{1}$ & 5 & 2.3 & 190 & 9 \\
\hline Eucalyptus grandis ${ }^{1}$ & 3 & 1.9 & 170 & 9 \\
\hline
\end{tabular}

${ }^{1}$ Greenhouse trial, ${ }^{2}$ Diameter of cork borer used for seedling inoculation. 
Table S7. Isolates of Botryosphaeriaceae species used in inoculation trials.

\begin{tabular}{lllll}
\hline Isolate & Botryosphaeriaceae species & \multicolumn{1}{c}{ Host } & \multicolumn{1}{c}{ Location } & Substrate \\
\hline CMW 39301 & Botryosphaeria dothidea & Chamaecyparis lawsoniana & Belgrade, Serbia & Pycnidia on branch \\
CMW 39315 & B. dothidea & C. lawsoniana & Bar, Montenegro & Branch canker \\
CMW 39327 & Neofusicoccum parvum & Sequoiadendron giganteum & Belgrade, Serbia & Necrotic needles \\
CMW 39317 & N. parvum & Eucalyptus globulus & Bar, Montenegro & Stem canker \\
CMW 39348 & Diplodia mutila & Cupressus sempervirens & Herceg Novi, Montenegro & Resinous branch canker \\
CMW 39385 & D. mutila & Thuja plicata & Belgrade, Serbia & Pycnidia on shoot \\
CMW 39376 & Diplodia seriata & Chamaecyparis pisifera & Belgrade, Serbia & Necrotic needles \\
CMW 39382 & D. seriata & Quercus robur & Morović, Serbia & Necrotic stem lesion \\
CMW 39364 & Dothiorella sarmentorum & C. lawsoniana & Belgrade, Serbia & Resinous branch lesion \\
CMW 39365 & Do. sarmentorum & Thuja occidentalis & Pirot, Serbia & Pycnidia on branch \\
CBS 135622 & Dothiorella sp. & C. atlantica & Belgrade, Serbia & Resinous branch lesion \\
CBS 135623 & Dothiorella sp. & T. plicata & Belgrade, Serbia & Dead resinous needles \\
CMW 39361 & Dothiorella omnivora & Cupressus sempervirens & Podgorica, Montenegro & Pycnidia on branch \\
CMW 39363 & Do. omnivora & C. lawsoniana & Belgrade, Serbia & Blue stained wood \\
CMW 39386 & Sphaeropsis visci & Viscum album & Mt Goč, Serbia & Pycnidia on leaves \\
CMW 39387 & Phaeobotryon cupressi & C. sempervirens & Podgorica, Montenegro & Resinous branch lesion \\
\hline
\end{tabular}


Table S8. Lesion/canker lengths (lengths of the necrotic/ discolored/resinous area at the site of inoculation) of seedlings and shoots inoculated with Botryosphaeriaceae species.

\begin{tabular}{|c|c|c|c|c|c|c|c|c|c|c|}
\hline \multicolumn{11}{|c|}{ Botryosphaeriaceae species } \\
\hline Host & $\begin{array}{c}\text { Botryosphaeria } \\
\text { dothidea }\end{array}$ & $\begin{array}{c}\text { Neofusicoccum } \\
\text { parvum }\end{array}$ & $\begin{array}{c}\text { Diplodia } \\
\text { seriata } \\
\end{array}$ & D. mutila & $\begin{array}{c}\text { Dothiorella } \\
\text { sarmentorum } \\
\end{array}$ & $\begin{array}{c}\text { Do. } \\
\text { omnivora }\end{array}$ & $\begin{array}{c}\text { Dothiorella } \\
\text { sp. } \\
\end{array}$ & $\begin{array}{c}\text { Phaeobotryon } \\
\text { cupressi }\end{array}$ & $\begin{array}{c}\text { Sphaeropsis } \\
\text { visci }\end{array}$ & Control \\
\hline $\begin{array}{l}\text { Chamaecyparis } \\
\text { lawsoniana }\end{array}$ & $\begin{array}{l}0.9-1.2(1)^{3} / \\
\underline{\mathbf{1 . 4 - 2 . 1 ( 1 . 9 )}}\end{array}$ & $0.9-1.1(0.9)$ & $0.9-1.2(1)$ & $0.9-1.1(0.9)$ & $0.9-1.2(1)$ & $0.9-1.3(1)$ & $0.9-1.4(1)$ & $\underline{2.7-8.3(4.7)}$ & $0.9-1.3(1)$ & $0.8-1(0.9)$ \\
\hline Cedrus atlantica & $0.4-0.6(0.5)$ & $\frac{\mathbf{1 . 9 - 2 . 6 ( 2 . 4 ) ^ { 5 }}}{0.4-0.6(0.5)^{6}}$ & $0.4-0.6(0.5)$ & $0.4-0.6(0.5)$ & $0.4-0.6(0.5)$ & & $0.4-0.6(0.5)$ & & & $0.4-0.5(0.5)$ \\
\hline C. deodara & & $0.4-0.6(0.5)^{5}$ & & & & & & & & $0.4-0.5(0.5)$ \\
\hline $\begin{array}{l}\text { Prunus } \\
\text { laurocerasus }\end{array}$ & & $\begin{array}{c}\frac{\mathbf{1 . 6 - 2 ( 1 . 8 )})^{5 /}}{1.8-2.2(2)}{ }^{6 /} \\
1-2.5(2.1)^{5,7} \\
2.9-3.5(3.3)\end{array}$ & & $\begin{array}{l}0.9-1.7(1.4)^{10} / \\
\frac{\mathbf{1 . 5}-\mathbf{2 . 2 ( 1 . 9 )}}{-^{10,7} /} \\
\mathbf{0 . 6 - 0 . 9 ( 0 . 8 )}\end{array}$ & & & & & & $\begin{array}{l}0.6-0.8 \\
(0.7) /-\end{array}$ \\
\hline $\begin{array}{l}\text { Pseudotsuga } \\
\text { menziesii }\end{array}$ & $0.4-0.6(0.5)$ & & & & & & & & & $0.4-0.5(0.5)$ \\
\hline $\begin{array}{l}\text { Juniperus } \\
\text { horizontalis }\end{array}$ & $\begin{array}{l}(1.2-2.7) 2^{3 /} \\
(1.3-2.6) 2^{4}\end{array}$ & & & & & & & & & - \\
\hline $\begin{array}{l}\text { Cupressus } \\
\text { arizonica }\end{array}$ & $\begin{array}{l}(1.3-1.7) 1.6{ }^{3} / \\
\underline{(4.2-9.8)}^{3.6}{ }^{4}\end{array}$ & & & $(1.3-1.7) 1.5$ & & & & & & - \\
\hline $\begin{array}{l}\text { Liriodendron } \\
\text { tulipifera }\end{array}$ & $\begin{array}{l}(6-30) 16.3^{3 /} \\
(5.4-8.3) 6.5^{4}\end{array}$ & & & & & & & & & 0.9-1.1 (1) \\
\hline $\begin{array}{l}\text { Magnolia } \\
\text { grandifolia }\end{array}$ & $\begin{array}{c}(1.3-2.5) 1.8^{3} / \\
(1.7-1.9) \\
1.8\end{array}$ & & & & & & & & & $0.4-0.5(0.4)$ \\
\hline $\begin{array}{l}\text { Ligustrum } \\
\text { vulgare }\end{array}$ & & & $\begin{array}{c}(1.4-2) 1.7^{8 /} \\
(1.7-2) 1.9^{9}\end{array}$ & & & & & & & - \\
\hline Quercus robur & & & $\frac{(1.9-7.5) 4.7}{(2.4-8.7) 5.3}^{8}$ & & & & & & & - \\
\hline $\begin{array}{l}\text { Pittosporum } \\
\text { tobira }\end{array}$ & & $\begin{array}{c}(1.2-1.5) 1.4^{5 /} \\
(1.7-2.1) 2^{6}\end{array}$ & & - & & & & & & - \\
\hline $\begin{array}{l}\text { Aesculus } \\
\text { hippocastanum }^{1}\end{array}$ & + & + & & + & $(1.5-3.5) 2.3^{12}$ & & & & & $(0.6-0.9) 0.7$ \\
\hline Pinus patula ${ }^{2}$ & $\begin{array}{l}(10-25) 16.5^{3} / \\
(13-33) 20.3^{4}\end{array}$ & $\begin{array}{c}(18-90) 36.8{ }^{5} \\
(32-80) 52.4^{6}\end{array}$ & & & & & & & & $6(6-7)$ \\
\hline $\begin{array}{l}\text { Eucalyptus } \\
\text { grandis }{ }^{2}\end{array}$ & $\begin{array}{c}(11-27) 15.4^{3} / \\
(10-17) 12.3^{4}\end{array}$ & $\begin{array}{l}27.3(12-48){ }^{5} / \\
80.5(37-140)^{6}\end{array}$ & & & & & & & & $6(6-7)$ \\
\hline
\end{tabular}


Table S8. Continued.

\begin{tabular}{|c|c|c|c|c|c|c|c|c|c|c|}
\hline \multicolumn{11}{|c|}{ Botryosphaeriaceae species } \\
\hline Host & $\begin{array}{c}\text { Botryosphaeria } \\
\text { dothidea }\end{array}$ & $\begin{array}{c}\text { Neofusicoccum } \\
\text { parvum }\end{array}$ & $\begin{array}{c}\text { Diplodia } \\
\text { seriata }\end{array}$ & D. mutila & $\begin{array}{c}\text { Dothiorella } \\
\text { sarmentorum } \\
\end{array}$ & $\begin{array}{c}\text { Do. } \\
\text { omnivora }\end{array}$ & $\begin{array}{c}\text { Dothiorella } \\
\text { sp. }\end{array}$ & $\begin{array}{c}\text { Phaeobotryon } \\
\text { cupressi }\end{array}$ & $\begin{array}{c}\text { Sphaeropsis } \\
\text { visci }\end{array}$ & Control \\
\hline Picea abies & $\begin{array}{c}(4-7.5) 5.8^{3} / \\
(2.5-4.3) 3.4^{4}\end{array}$ & $(2.5-6.5) 3^{5}$ & & & & & & & & - \\
\hline Populus nigra & - & $\frac{(\mathbf{3 . 3}-5.6) \mathbf{4 . 2}}{(1.7-2.6) 2.3^{5}}$ & & & & & & & & - \\
\hline Quercus rubra & & $0.4-0.7(0.5)$ & $0.4-0.6(0.5)$ & & $0.4-0.8(0.5)$ & & & & & $0.4-0.5(0.5)$ \\
\hline Taxus baccata & $(0.7-1) 0.8$ & & & & & & & & & $(0.6-0.8) 0.7$ \\
\hline Prunus cerasus & $(0.7-0.9) 0.8$ & & & & & & & & & (0.6-0.9) 0.7 \\
\hline Populus tremula ${ }^{1}$ & $\begin{array}{l}(1.5-2.3) 2^{3} / \\
(1-2.2) 1.9^{4}\end{array}$ & & & & & & & & & - \\
\hline Quercus cerris & $\begin{array}{c}(1.7-2.6) 2^{3 /} \\
(1-2.3) 1.9^{4}\end{array}$ & & & & & & & & & - \\
\hline Fraxinus excelsior & & & $(1.2-2.3) 1.7^{8}$ & & & - & & & & - \\
\hline
\end{tabular}

Mean lesion lengths (cm) are given in brackets;"- “ indicate that lesions/cankers were not formed; "+” indicate that all inoculated shoots were girdeled; Lesions statistically larger compared to controls are given in bold $(\alpha=0.05)$. Cankers are given in bold and underlined. Lesions statistically larger compared to those produced by the other isolate of the same species are given in italics $(\alpha=0.05)$. ${ }^{1}$ Branch inoculations, ${ }^{2}$ Greenhouse trial, ${ }^{3} \mathrm{CMW} 39301,{ }^{4} \mathrm{CMW} 39315,{ }^{5} \mathrm{CMW} 39327,{ }^{6} \mathrm{CMW}$ 39317, ${ }^{7}$ Leaf inoculations, ${ }^{8} \mathrm{CMW} 39376,{ }^{9} \mathrm{CMW} 39382,{ }^{1}$ CMW 39348, ${ }^{11}$ CMW 39385, ${ }^{12}$ CMW 39365. 
Table S9. New hosts reported for Botryosphaeriaceae species identified in the present study.

\begin{tabular}{|c|c|c|c|}
\hline $\begin{array}{l}\text { Botryosphaeriaceae } \\
\text { species }\end{array}$ & New host-fungus association & $\begin{array}{c}\text { Botryosphaeriaceae } \\
\text { species }\end{array}$ & New host-fungus association \\
\hline Do. sarmentorum & $\begin{array}{l}\text { Quercus rubra } \\
\text { Cryptomeria japonica } \\
\text { Forsythia europaea } \\
\text { Thuja plicata } \\
\text { Thuja occidentalis }\end{array}$ & D. mutila & $\begin{array}{l}\text { Pittosporum tobira } \\
\text { Prunus laurocerasus } \\
\text { C. sempervirens } \\
\text { Chamaecyparis obtusa } \\
\text { C. atlantica } \\
\text { T. plicata }\end{array}$ \\
\hline Do. omnivora & Sequoiadendron giganteum & D. seriata & $\begin{array}{l}\text { Quercus robur } \\
\text { A. concolor } \\
\text { S. caprea } \\
\text { Prunus cerasus } \\
\text { Q. rubra }\end{array}$ \\
\hline B. dothidea & $\begin{array}{l}\text { C. atlantica } \\
\text { Chamaecyparis lawsoniana } \\
\text { T. occidentalis } \\
\text { T. plicata } \\
\text { Cupressus arizonica } \\
\text { Abies concolor } \\
\text { Picea abies } \\
\text { Juniperus horizontalis } \\
\text { Magnolia grandiflora } \\
\text { Liriodendron tulipifera } \\
\text { Platanus acerifolia } \\
\text { Aesculus hippocastanum } \\
\text { Salix caprea } \\
\text { C. sempervirens } \\
\text { Taxus baccata } \\
\text { Quercus cerris } \\
\text { Populus tremula }\end{array}$ & N. parvum & $\begin{array}{l}\text { C. obtusa } \\
\text { Chamaecyparis pisifera } \\
\text { T. occidentalis } \\
\text { Sequoia sempervirens } \\
\text { Pinus halepensis } \\
\text { P. abies } \\
\text { S. caprea }\end{array}$ \\
\hline
\end{tabular}


Table S10. Percentages of isolates of Botryosphaeriaceae species associated with gymnosperms and angiosperms.

\begin{tabular}{lcc}
\hline \multicolumn{1}{c}{ Botryosphaeriaceae species } & $\begin{array}{c}\text { Gymnosperms } \\
(\%)\end{array}$ & $\begin{array}{c}\text { Angiosperms } \\
(\%)\end{array}$ \\
\hline Botryosphaeria dothidea & 54.5 & 45.5 \\
Neofusicoccum parvum & 60 & $40^{1}$ \\
Diplodia sapinea & 93.8 & $6.2^{1}$ \\
D. mutila & 72.7 & $27.3^{1}$ \\
D. seriata & 50 & 50 \\
Dothiorella sp. & 100 & $/$ \\
Do. sarmentorum & 62.5 & $37.5^{1}$ \\
Do. omnivora & 80 & $20^{1}$ \\
Phaeobotryon cupressi & 100 & $/$ \\
Sphaeropsis visci & $/$ & 100 \\
\hline
\end{tabular}

\footnotetext{
${ }^{1}$ Percentage of isolates obtained from angiosperms differed significantly from percentage of isolates obtained from gymnosperms as determined by the $\mathrm{z}$ test at $\mathrm{z}>1.96, \mathrm{p}<0.05$. Data refer to the whole set of Botryosphaeriaceae isolates from the Western Balkans region, including isolates from this and from previous studies (Zlatković et al. 2016a, b, 2017).
}

Table S11. Diversity of Botryosphaeriaceae species isolated from hosts in the Continental and Mediterranean climate regions and from gymnosperms and angiosperms.

\begin{tabular}{lccccc}
\hline $\begin{array}{l}\text { Climate region/ } \\
\text { Host group }\end{array}$ & $\begin{array}{c}\text { Species } \\
\text { richness (S) }\end{array}$ & Abundance & $\begin{array}{c}\text { Shannon } \\
\text { index (H') }\end{array}$ & $\begin{array}{c}\text { Evenness } \\
(\mathrm{J})\end{array}$ & $\begin{array}{c}\text { Jaccard's } \\
\text { index (J') }\end{array}$ \\
\hline $\begin{array}{l}\text { Continental } \\
\text { Mediterranean }\end{array}$ & 9 & 262 & 0.30 & 0.77 & 0.5 \\
Gymnosperms & 6 & 47 & 0.37 & 0.8 & \\
Angiosperms & 8 & 254 & 0.29 & 0.76 & 0.7 \\
Total & 10 & 55 & 0.42 & 0.8 & \\
\hline
\end{tabular}

Data refer to the whole set of Botryosphaeriaceae isolates from the Western Balkans, including isolates from this and from previous studies (Zlatković et al. 2016a, b, 2017). 
Table S12. Botryosphaeriaceae species isolated from the same tree and same host tissues.

Botryosphaeriaceae species composition (one tree) Host

Botryosphaeria dothidea / Diplodia seriata

B. dothidea / Diplodia mutila

B. dothidea / Diplodia sapinea

B. dothidea / Neofusicoccum parvum

B. dothidea / Dothiorella sp.

B. dothidea / N. parvum / Dothiorella omnivora

B. dothidea / N. parvum / D. mutila

B. dothidea / D. mutila/ Dothiorella sarmentorum

B. dothidea / D. sapinea / D. mutila / D. seriata / Do. sarmentorum

N. parvum / D. sapinea

N. parvum / D. seriata

N. parvum / D. mutila

N. parvum / Do. sarmentorum

N. parvum / D. seriata / Do. sarmentorum

Do. sarmentorum / Dothiorella sp.

Do. sarmentorum / D. mutila

Do. sarmentorum / D. seriata

Do. omnivora / Phaeobotryon cupressi

Do. omnivora / D. seriata
Chamaecyparis lawsoniana

Salix caprea

Cupressus arizonica

Cedrus atlantica

Pseudotsuga menziesii

Sequoiadendron giganteum

C. lawsoniana

Aesculus hippocastanum

Populus nigra var. italica

C. atlantica

S. giganteum

Sequoia sempervirens

Thuja plicata

C. atlantica

C. atlantica

Chamaecyparis pisifera

C. atlantica

Chamaecyparis obtusa

Pittosporum tobira

Prunus laurocerasus

A. hippocastanum

Quercus rubra

C. atlantica

C. lawsoniana

Thuja occidentalis

Cupressus sempervirens

Fraxinus excelsior

Data refer to the whole set of Botryosphaeriaceae isolates from the Western Balkans, including isolates from this and from previous studies (Zlatković et al. 2016a, b, 2017). 
Table S13. Frequency of occurrence of multiple Botryosphaeriaceae species cohabiting in diseased host trees (A) and within diseased tree parts (B, see Table 2) in this and in previous studies in the Western Balkans (Zlatković et al. 2016a, b, 2017).

\begin{tabular}{|c|c|c|c|c|c|}
\hline Cohabiting Botryosphaeriaceae species (A) & $\begin{array}{c}\text { Frequency } \\
\text { of } \\
\text { occurrence } \\
(\%) \\
\end{array}$ & $\begin{array}{l}\text { Cohabiting Botryosphaeriaceae } \\
\text { species (B) }\end{array}$ & $\begin{array}{c}\text { Frequency } \\
\text { of } \\
\text { occurrence } \\
(\%) \\
\end{array}$ & $\begin{array}{l}\text { Botryosphaeriaceae } \\
\text { species }\end{array}$ & $\begin{array}{c}\text { Frequency } \\
\text { of } \\
\text { occurrence } \\
(\%) \\
\end{array}$ \\
\hline & & & \multicolumn{3}{|c|}{ (A) } \\
\hline Botryosphaeria dothidea / Diplodia seriata & 6 & B. dothidea / D. mutila & 13 & B. dothidea & 30.6 \\
\hline B. dothidea / Diplodia mutila & 12 & B. dothidea / D. sapinea & 13 & N. parvum & 22.4 \\
\hline B. dothidea / Diplodia sapinea & 10 & B. dothidea / N. parvum & 6 & D. mutila & 17.6 \\
\hline B. dothidea / Neofusicoccum parvum & 16 & B. dothidea / Dothiorella sp. & 6 & D. seriata & 12.9 \\
\hline B. dothidea / Dothiorella omnivora & 2 & B. dothidea / Do. sarmentorum & 6 & D. sapinea & 10.6 \\
\hline B. dothidea / Dothiorella sp. & 2 & N. parvum / D. sapinea & 6 & Dothiorella sp. & 2.4 \\
\hline B. dothidea / Dothiorella sarmentorum & 4 & N. parvum / D. mutila & 6 & Do. omnivora & 2.4 \\
\hline N. parvum / D. sapinea & 2 & N. parvum / Do. sarmentorum & 6 & P. cupressi & 1.2 \\
\hline N. parvum / D. seriata & 4 & D. sapinea/ D. seriata & 6 & (B) & \\
\hline N. parvum / D. mutila & 10 & Do. sarmentorum / D. mutila & 13 & B. dothidea & 24.5 \\
\hline N. parvum / Do. sarmentorum & 4 & Do. sarmentorum / Dothiorella sp. & 6 & N. parvum & 22.4 \\
\hline N. parvum/Do. omnivora & 2 & Dothiorella sp. / D. seriata & 6 & D. sapinea & 10.2 \\
\hline D. sapinea/ D. mutila & 2 & & & Do. sarmentorum & 10.2 \\
\hline D. sapinea/ D. seriata & 2 & & & D. seriata & 6.1 \\
\hline D. mutila/ D. seriata & 2 & & & Dothiorella sp. & 4.1 \\
\hline Do. sarmentorum/D. sapinea & 2 & & & D. mutila & 2 \\
\hline Do. sarmentorum / Dothiorella sp. & 2 & & & Do. omnivora & 2 \\
\hline Do. sarmentorum / D. mutila & 6 & & & & \\
\hline Do. sarmentorum / D. seriata & 6 & & & & \\
\hline Do. omnivora / Phaeobotryon cupressi & 2 & & & & \\
\hline Do. omnivora/ D. seriata & 2 & & & & \\
\hline
\end{tabular}

Cohabiting Botryosphaeriaceae species with the highest frequency in diseased host trees/within diseased tree parts are given in bold and shaded. 
Table S14. Frequency of isolation of multiple Botryosphaeriaceae species from the same tree of a variety of tree species.

\begin{tabular}{ll}
\hline \multicolumn{1}{c}{ Host } & Frequency (\%) \\
\hline Cedrus atlantica & 22.2 \\
Chamaecyparis lawsoniana & 11.1 \\
Sequoiadendron giganteum & 7.4 \\
Aesculus hippocastanum & 7.4 \\
Cupressus arizonica & 3.7 \\
Pseudotsuga menziesii & 3.7 \\
Pinus nigra & 3.7 \\
Sequoia sempervirens & 3.7 \\
Thuja plicata & 3.7 \\
Chamaecyparis pisifera & 3.7 \\
Chamaecyparis obtusa & 3.7 \\
Pittosporum tobira & 3.7 \\
Prunus laurocerasus & 3.7 \\
Quercus rubra & 3.7 \\
Thuja occidentalis & 3.7 \\
Cupressus sempervirens & 3.7 \\
Fraxinus excelsior & 3.7 \\
\hline
\end{tabular}

Data refer to the whole set of Botryosphaeriaceae isolates from the Western Balkans, including isolates from this and from previous studies (Zlatković et al. 2016a, b, 2017). 
Table S15. Analyses of variance (ANOVA) and Kruskal-Wallis $\mathrm{H}$ test results for the effect of Botryosphaeriaceae isolates on the extent of vascular discoloration/resinous lesions associated with a variety of tree species in this study.

\section{Chamaecyparis lawsoniana}

\begin{tabular}{|c|c|}
\hline \multirow{2}{*}{ Botryosphaeria dothidea } & CMW $39301 \times C$ \\
\hline & $\mathrm{H}=1.94, \mathrm{df}=1, \mathrm{p}=0.16$ \\
\hline \multirow{2}{*}{ Neofusicoccum parvum } & CMW $39327 \times$ C / CMW $39317 \times$ C \\
\hline & $\mathrm{H}=1.94, \mathrm{df}=1, \mathrm{p}=1.16$ \\
\hline Diplodia seriata & CMW $39376 \times$ C / CMW $39382 \times$ C \\
\hline D. mutila & CMW $39348 \times$ C / CMW $39385 \times$ C \\
\hline Dothiorella sarmentorum & CMW $39364 \times$ C / CMW $39365 \times$ C \\
\hline Do. omnivora & CMW $39361 \times$ C / CMW $39363 \times C$ \\
\hline \multirow[t]{2}{*}{ Dothiorella sp. } & CBS $135622 \times$ C / CBS $135623 \times C$ \\
\hline & $\mathrm{H}=1.06, \mathrm{df}=1, \mathrm{p}=0.3$ \\
\hline \multirow[t]{2}{*}{ Sphaeropsis visci } & CMW $39386 \times C$ \\
\hline & $\mathrm{H}=1.17, \mathrm{df}=1, \mathrm{p}=0.28$ \\
\hline \multicolumn{2}{|r|}{ Magnolia grandifolia } \\
\hline \multirow{4}{*}{ B. dothidea } & CMW $39315 \times C$ \\
\hline & $H=15.14, d f=1, p=0.0001$ \\
\hline & CMW $39301 \times$ CMW 39315 \\
\hline & $\mathrm{F}=0.29, \mathrm{df}=1, \mathrm{p}=0.6$ \\
\hline \multicolumn{2}{|r|}{ Liriodendron tulipifera } \\
\hline \multirow{4}{*}{ B. dothidea } & CMW $39315 \times C$ \\
\hline & $\mathrm{F}=35.7, \mathrm{df}=1, \mathrm{p}=0.000012$ \\
\hline & CMW $39301 \times$ CMW 39315 \\
\hline & $\mathrm{F}=14.38, \mathrm{df}=1, \mathrm{p}=0.001$ \\
\hline \multicolumn{2}{|r|}{ Pseudotsuga menziesii } \\
\hline \multirow[t]{2}{*}{ B. dothidea } & CMW $39301 \times$ C / CMW $39315 \times C$ \\
\hline & $\mathrm{F}=3.08, \mathrm{df}=1, \mathrm{p}=0.1$ \\
\hline \multicolumn{2}{|r|}{ Cedrus deodara } \\
\hline \multirow[t]{2}{*}{ N. parvum } & CMW $39327 \times C$ \\
\hline & $F=3.86, d f=1, p=0.06$ \\
\hline
\end{tabular}


Table S15. Continued.

\section{Cedrus atlantica}

\begin{tabular}{|c|c|}
\hline \multirow[t]{2}{*}{ Botryosphaeria dothidea } & CMW $39301 \times \mathrm{C} / \mathrm{CMW} 39315 \times \mathrm{C}$ \\
\hline & $\mathrm{F}=3.08, \mathrm{df}=1, \mathrm{p}=0.1$ \\
\hline \multirow[t]{2}{*}{ Neofusicoccum parvum } & CMW $39327 \times$ C \\
\hline & $\mathrm{F}=0.95, \mathrm{df}=1, \mathrm{p}=0.34$ \\
\hline \multirow[t]{2}{*}{ Diplodia seriata } & CMW $39327 \times$ C \\
\hline & $\mathrm{F}=0.95, \mathrm{df}=1, \mathrm{p}=0.34$ \\
\hline \multirow[t]{2}{*}{ D. mutila } & CMW $39358 \times$ C / CMW $39348 \times C$ \\
\hline & $\mathrm{F}=1.8, \mathrm{df}=1, \mathrm{p}=0.2$ \\
\hline Dothiorella sarmentorum & CMW $39364 \times$ C / CMW $39365 \times$ C \\
\hline \multirow[t]{2}{*}{ Dothiorella sp. } & CBS $135622 \times$ C / CBS $135623 \times C$ \\
\hline & $F=0.53, d f=1, p=0.48$ \\
\hline \multicolumn{2}{|c|}{ Quercus rubra } \\
\hline \multirow[t]{2}{*}{ N. parvum } & CMW $39327 \times$ C / CMW $39317 \times$ C \\
\hline & $F=0.11, d f=1, p=0.75$ \\
\hline \multirow[t]{2}{*}{ D. seriata } & CMW $39382 \times$ C / CMW $39376 \times C$ \\
\hline & $F=1.53, d f=1, p=0.23$ \\
\hline \multirow[t]{2}{*}{ Do. sarmentorum } & CMW $39364 \times$ C / CMW $39365 \times$ C \\
\hline & $\mathrm{F}=0.06, \mathrm{df}=1, \mathrm{p}=0.81$ \\
\hline
\end{tabular}

Taxus baccata

\begin{tabular}{cc}
\hline B. dothidea & CMW $39301 \times \mathrm{C} / \mathrm{CMW} 39315^{\times} \mathrm{C}$ \\
$\mathrm{H}=2.08, \mathrm{df}=1, \mathrm{p}=0.15$ \\
\hline
\end{tabular}

Prunus cerasus

D. seriata CMW $39382 \times \mathrm{C} / \mathrm{CMW} 39376 \times \mathrm{C}$

$\mathrm{H}=1.34, \mathrm{df}=1, \mathrm{p}=0.25$

\section{Aesculus hippocastanum}

Do. sarmentorum

CMW $39365 \times \mathrm{C}$

$\mathrm{F}=48.03, \mathrm{df}=1, \mathrm{p}=0.000002$

\section{Populus tremula}

B. dothidea

CMW $39301 \times$ CMW 39315

$\mathrm{F}=0.42, \mathrm{df}=1, \mathrm{p}=0.52$ 
Table S15. Continued.

\begin{tabular}{|c|c|}
\hline \multicolumn{2}{|r|}{ Quercus cerris } \\
\hline \multirow[t]{2}{*}{ Botryosphaeria dothidea } & CMW $39301 \times$ CMW 39315 \\
\hline & $\mathrm{F}=0.5, \mathrm{df}=1, \mathrm{p}=0.47$ \\
\hline \multicolumn{2}{|r|}{ Pinus patula } \\
\hline \multirow[t]{6}{*}{ Neofusicoccum parvum } & CMW $39327^{\times} \mathrm{C}$ \\
\hline & $\mathrm{F}=21.5, \mathrm{df}=1, \mathrm{p}=0.0002$ \\
\hline & CMW $39317^{\times} \mathrm{C}$ \\
\hline & $\mathrm{F}=50.5, \mathrm{df}=1, \mathrm{p}=0.000001$ \\
\hline & CMW $39327 \times$ CMW 39317 \\
\hline & $\mathrm{F}=2.2, \mathrm{df}=1, \mathrm{p}=0.15$ \\
\hline \multirow[t]{9}{*}{ B. dothidea } & CMW $39301 \times C$ \\
\hline & $F=53.2, d f=1, p=0.000001$ \\
\hline & CMW $39315 \times$ C \\
\hline & $\mathrm{F}=47.4, \mathrm{df}=1, \mathrm{p}=0.000002$ \\
\hline & CMW $39301 \times$ CMW 39315 \\
\hline & $\mathrm{F}=2.9, \mathrm{df}=1, \mathrm{p}=0.14$ \\
\hline & CMW $39329^{\times} \mathrm{CMW} 39337^{\times} \mathrm{CMW} 39327^{\times} \mathrm{CMW} 39317^{\times}$ \\
\hline & CMW $39301 \times$ CMW 39315 \\
\hline & $\mathrm{H}=40.22, \mathrm{df}=5, \mathrm{p}=0$ \\
\hline \multicolumn{2}{|r|}{ Eucalyptus grandis } \\
\hline \multirow[t]{6}{*}{ N. parvum } & CMW $39327^{\times} \mathrm{C}$ \\
\hline & $\mathrm{F}=35.78, \mathrm{df}=1, \mathrm{p}=0.000012$ \\
\hline & CMW $39317^{\times} \mathrm{C}$ \\
\hline & $\mathrm{F}=34, \mathrm{df}=1, \mathrm{p}=0.000016$ \\
\hline & CMW $39327 \times$ CMW 39317 \\
\hline & $\mathrm{F}=16.19, \mathrm{df}=1, \mathrm{p}=0.0008$ \\
\hline \multirow[t]{6}{*}{ B. dothidea } & CMW $39301 \times C$ \\
\hline & $\mathrm{F}=36.27, \mathrm{df}=1, \mathrm{p}=0.00001$ \\
\hline & CMW $39317^{\times} \mathrm{C}$ \\
\hline & $\mathrm{F}=73.28, \mathrm{df}=1, \mathrm{p}=0$ \\
\hline & CMW $39301 \times$ CMW 39315 \\
\hline & $\mathrm{F}=3.43, \mathrm{df}=1, \mathrm{p}=0.08$ \\
\hline
\end{tabular}


Table S15. Continued.

\section{Eucalyptus grandis}

Botryosphaeria dothidea

CMW 39329 ${ }^{\times}$CMW $39337^{\times}$CMW $39327^{\times}$CMW $39317^{\times}$
CMW $39301 \times$ CMW 39315
$H=39.64, d f=5, p=0$

- Cankers/necrotic lesions were not detected on the control plants. The log10 transformation was used to improve normality of the data set in order to analyse the effect of B. dothidea isolate CMW 39315 on vascular discoloration of L. tulipifera seedlings. 